\title{
JOVENS BRASILEIROS: O CONFLITO ENTRE ESTUDO E TRABALHO E A CRISE DE DESEMPREGO
}

\section{NANCY DE DEUS VIEIRA SILVA}

Bacharel em Ciências Econômicas

Orientadora: Profa. Dra. ANA LÚCIA KASSOUF

Tese apresentada à Escola Superior de Agricultura "Luiz de Queiroz", Universidade de São Paulo, para obtenção do título de Doutor em Ciências, Área de Concentração: Economia Aplicada.

PIRACICABA

Estado de São Paulo - Brasil

Outubro - 2001 


\section{Dados Internacionais de Catalogação na Publicação (CIP) DIVISÃO DE BIBLIOTECA E DOCUMENTAÇÃO - ESALQ/USP}

Silva, Nancy de Deus Vieira

Jovens brasileiros : o conflito entre estudo e trabalho e a crise de desemprego / Nancy de Deus Vieira Silva. - - Piracicaba, 2001.

$134 \mathrm{p}$.

Tese (doutorado) - Escola Superior de Agricultura Luiz de Queiroz, 2001.

Bibliografia.

1. Brasil 2. Desemprego 3. Economia aplicada 4. Escolarização 5. Jovem 6. Mercado de trabalho I. Titulo

CDD 331.12

Mermitida a cópia total ou parcial deste documento, desde que citada a fonte -0 autor" 
Dedico

Ao amor de minha vida:

Edivaldo.

Às maiores alegrias que Deus me concedeu:

Fernanda,

e o Bebê que está para chegar.

$\grave{A}$ Deus,

Por ter me presenteado com essas criaturas maravilhosas. 


\section{AGRADECIMENTOS}

À Profa. Ana Lúcia Kassouf, pela orientação dedicada, competente e pelo dinamismo com que acompanhou todas as etapas para a realização deste trabalho. Mais que isso, meu reconhecimento, admiração e o mais profundo respeito pelo seu profissionalismo exemplar. Aos professores Dr. José Vicente Caixeta Filho, Dr. Paulo Fernando Cidade de Araújo, Dr. Joaquim José Martins Guilhoto e Dr. Fernando Curi Péres pelas valiosas críticas e sugestões que contribuíram para a elaboração e o aprimoramento desta tese.

Ao corpo docente do Departamento de Economia, Administração e Sociologia da ESALQ/USP pelos importantes ensinamentos recebidos.

Ao Conselho Nacional de Desenvolvimento Científico e Tecnológico, (CNPq), pela bolsa concedida, o que viabilizou financeiramente a concretização de meu doutorado.

A todos os colegas e grandes amigos do curso de pós-graduação, pela amizade, companheirismo, estímulo e principalmente por tudo que aprendi com vocês.

Finalmente, expresso minha sincera gratidão e admiração à meus grandes amigos do doutorado que muito me ajudaram para concluir este trabalho: Márcia, Jaenes e Cândida, pela calorosa acolhida, solidariedade, cumplicidade e carinho. 


\section{SUMÁRIO}

Página

LISTA DE FIGURAS......................................................................... vii

LISTA DE TABELAS ........................................................................ viii

RESUMO ......................................................................................... xiii

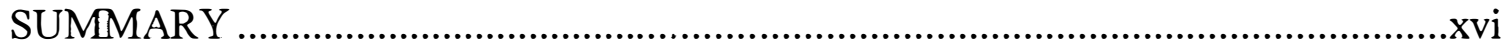

1 INTRODUÇÃ

1.1 Importância do problema e justificativas............................................. 6

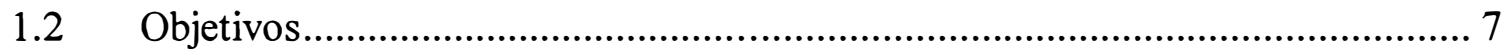

1.3 Organização deste estudo ...................................................................... 9

2 REVISÃO DE LITERATURA .............................................................11

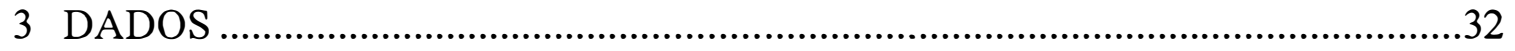

4 ANÁLISE DESCRITIVA DOS DADOS ….................................................... 34

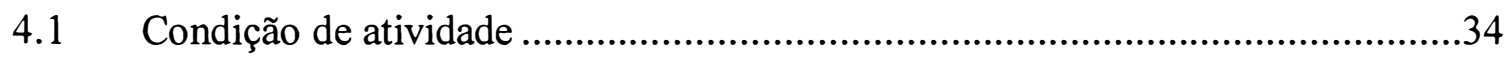

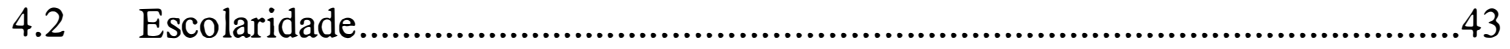

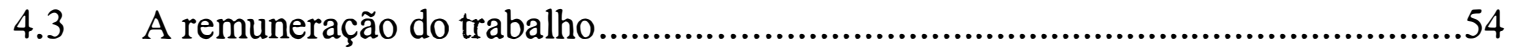

4.4 Características familiares..................................................................60

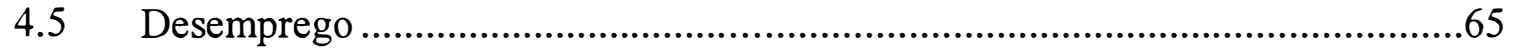

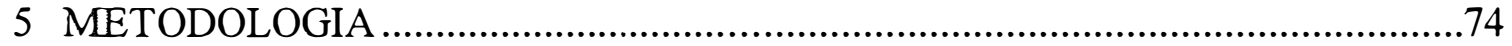

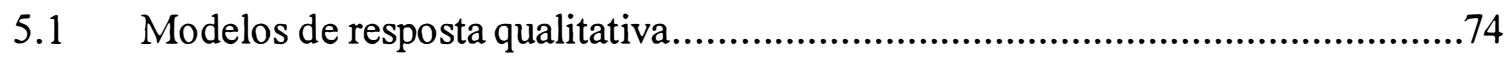

5.1.1 Equações de trabalho e freqüência à escola................................................75

5.1.2 Equações inatividade, emprego e desemprego ............................................78

5.2 Descrição das variáveis exógenas .............................................................78

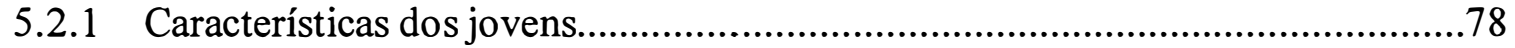

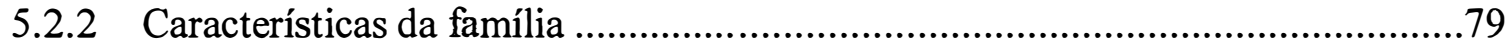

5.2.3 Proxy para fator demanda................................................................. 81 
6 RESULTADOS DOS MODELOS ECONOMÉTRICOS ....................................85

6.1 Equações de trabalho e freqüência à escola ..................................................85

6.1.1 Equações de trabalho e freqüência à escola para jovens das áreas urbanas ........86

6.1.2 Equações de trabalho e freqüência à escola para jovens das áreas rurais ..........92

6.2 Equações de inatividade, emprego e desemprego para jovens .........................95

6.2.1 Equações de inatividade, emprego e desemprego para homens jovens das

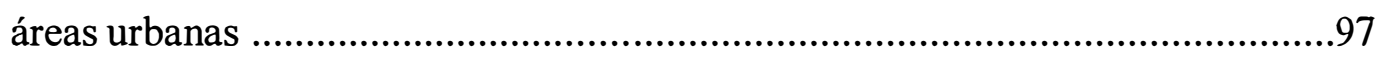

6.2.2 Equações de inatividade, emprego e desemprego para mulheres jovens das áreas urbanas..................................................................................104

6.2.3 Equações de inatividade, emprego e desemprego das áreas rurais...................109

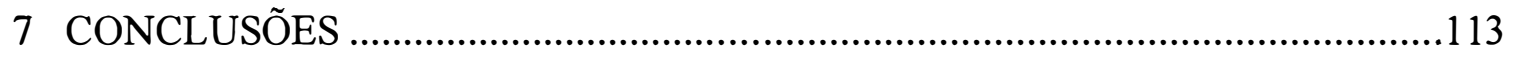

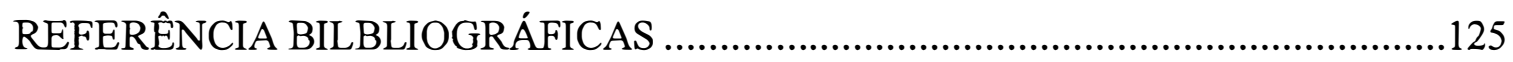

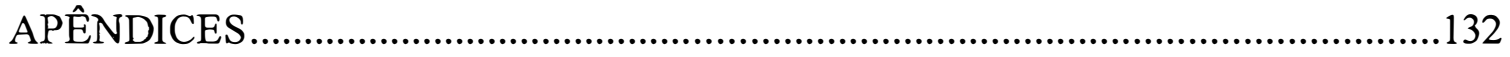




\section{LISTA DE FIGURAS}

Página

1 Proporção de jovens economicamente ativos, em 1995, estratificados por sexo e faixa etária, 15 a 19 e 20 a 24 anos

2 Taxas de analfabetismo para alguns países da América Latina em 1999

3 Taxas de desemprego para diversos países estratificado por adultos (25 ou mais anos de idade) e jovens (15 a 24 anos) e por gênero - Brasil, Argentina e Portugal em1996 e demais países em1998.

4 Proporção de jovens na escola, trabalhando ou não, por sexo e setor ................ 44

5 Anos de escolaridade para jovens que trabalham ou não ................................. 47

6 Porcentagem de jovens de 15 a 24 anos em diferentes categorias..................... 49

7 Taxa de desemprego dos jovens estratificada por situação de domicílio, gênero e idade 


\section{LISTA DE TABELAS}

Página

1 Taxas de desemprego para diversos países para o período de 1986 a 1993 e 1997

2 Taxa de atividade dos jovens e adultos, estratificada por gênero e por categorias (situação de domicílio, regiões, escolaridade, cor e posição no domicílio)

3 Porcentagem de jovens trabalhando e porcentagem de jovens trabalhando que recebem pagamento, estratificada por grupo de idade, sexo e situação de domicílio

4 Porcentagem de jovens e adultos trabalhando, estratificada por sexo e mercado de trabalho

5 Porcentagem de jovens rabalhando, estratificada por atividades, situação de domicílio, sexo e grupos de idade.

6 Porcentagem de jovens de 15 a 24 anos de idade, estratificado por idade de ingresso no mercado de trabalho, situação de domicílio e sexo

7 Tempo de trabalho dos jovens (empregados) na ocupação atual, estratificado por situação de domicílio, sexo e grupo de idade

8 Número médio de anos de escolaridade entre jovens que trabalham e não trabalham, estratificado pela idade, sexo, e situação do domicílio 
9 Anos de escolaridade dos jovens de 15 a 24 anos de idade, estratificado por idade de ingresso no mercado de trabalho, situação de domicílio e sexo

10 Distribuição percentual de jovens por situação de freqüência à escola e condição de atividade segundo o rendimento familiar mensal per capita (Salário Mínimo), excluindo o rendimento dos jovens, e grupos de idade.

11 Porcentagem de jovens trabalhando, estratificada pelo número de horas de trabalho semanais, por situação de domicílio, sexo e grupo de idade

12 Porcentagem de jovens trabalhando, estratificada pelo número de horas de trabalho semanais, por situação de domicílio, sexo e grupo de idade e se freqüentam ou não escola.

13 Porcentagem de jovens trabalhando e recebendo pagamento, estratificada pelo rendimento por hora, situação de domicílio, sexo e grupo de idade.

14 Porcentagem de jovens trabalhando e recebendo pagamento, estratificada pelo salário mínimo mensal, por situação de domicílio, sexo e grupo de idade

15 Rendimento médio (por hora trabalhada) estratificado por setor, situação de domicílio, sexo e grupo de idade, valores expressos em Reais 56

16 Rendimento médio (por hora trabalhada) estratificado por anos de escolaridade, situação de domicílio, sexo e grupos de idade, valores expressos em Reais 
17 Rendimento médio (por hora trabalhada) estratificado por regiões, situação de domicílio, sexo e grupos de idade, valores expressos em Reais

18 Porcentagem de famílias em que os rendimentos dos jovens contribuem para certa porcentagem da renda familiar, estratificada por situação de domicílios e grupos de idade

19 Porcentagem de jovens trabalhando ou não, de acordo com a renda familiar per capita, excluindo os rendimentos dos jovens, estratificada pela situação do domicílio e grupos de idade

20 Porcentagem de jovens trabalhando, de acordo com o setor de ocupação do chefe de família, estratificada por grupos de idade e pela situação do domicílio

21 Porcentagem de jovens trabalhando, de acordo com a inserção do chefe de família no mercado de trabalho, estratificada por grupos de idade e pela situação do domicílio.

22 Taxa de desemprego dos jovens e adultos, estratificada por gênero e por categorias (situação de domicílio, regiões, escolaridade, cor e posição no domicílio).

23 Descrição das variáveis utilizadas nas equações de trabalho e freqüência à escola, médias e desvios padrões, para homens e mulheres jovens nas áreas urbanas e rurais

24 Descrição das variáveis utilizadas nas equações de inatividade, emprego e desemprego, médias e desvios padrões, para homens e mulheres jovens nas áreas urbanas e rurais 
25 Porcentagem de jovens de 15 a 24 anos em seis categorias mutuamente exclusivas.

26 Equações de trabalho e freqüência à escola para homens jovens, com residência urbana

27 Equações de trabalho e freqüência à escola para mulheres jovens, com residência urbana

28 Equações de trabalho e freqüência à escola para homens jovens, com residência rural.

29 Equações de trabalho e freqüência à escola para mulheres jovens, com residência rural

30 Porcentagem de jovens de 15 a 24 anos de acordo com sua condição de atividade no período de 20 a 26 de setembro de 1998 97

31 Equações de inatividade, emprego e desemprego para homens jovens, com residência urbana.

32 Taxas de inatividade, emprego e desemprego, para homens jovens de 15 a 24 anos de idade, estratificado por região, em 1998

33 Equações de inatividade, emprego e desemprego para mulheres jovens, com residência urbana.

34 Porcentagem de indivíduos inativos, empregados e desempregados, para mulheres residentes nas áreas urbanas, estratificado por posição no domicílio 107

35 Equações de inatividade, emprego e desemprego para homens jovens, com residência rural 
36 Equações de inatividade, emprego e desemprego para mulheres jovens, com residência rural ....................................................................... 112 


\title{
JOVENS BRASILEIROS: O CONFLITO ENTRE ESTUDO E TRABALHO E A CRISE DE DESEMPREGO
}

\author{
Autora: NANCY DE DEUS VIEIRA SILVA \\ Orientadora: Profa. Dra. ANA LUCIA KASSOUF
}

\section{RESUMO}

No Brasil havia em 1998 mais de 31 milhões de jovens com idade entre $15 \mathrm{e}$ 24 anos, correspondendo a 19,5\% do total da população. Este estudo visa diagnosticar a situação destes jovens no mercado de trabalho. Busca conhecer suas condições sócioeconômicas, particularmente seu nível educacional, bem como, avaliar a magnitude e os determinantes do desemprego da juventude brasileira. Foram utilizados microdados da Pesquisa Nacional por Amostra de Domicílios (PNAD) de 1998.

A inserção dos jovens no mercado de trabalho se dá de forma bastante desfavorável. Em primeiro lugar, o ingresso dos jovens no mundo do trabalho é muito precoce, grande parte teve seu primeiro trabalho com 12 anos ou menos. O desemprego atinge 3,3 milhões de jovens, os quais representam $49 \%$ do total de desempregados brasileiros. A maioria trabalha no mercado informal (65\%) e grande parte trabalha mais que as 44 horas previstas pela legislação. Ademais, seus rendimentos são muito baixos, recebem, em média, cerca de $50 \%$ dos rendimentos dos adultos.

Estes jovens ainda estão em idade de formação, e têm que dividir seu tempo entre estudar e trabalhar. Os problemas enfrentados por eles no mercado de trabalho interferem diretamente em sua escolaridade. Embora o perfil educacional dos jovens brasileiros tenha melhorado, esse indicador ainda é bastante baixo quando comparado com outros países. Em média a escolaridade dos jovens brasileiros era, em 1998, de 6,7 anos, enquanto na Argentina era de 9,2, no Uruguai de 8,1 e no Chile 7,8. Ademais, as taxas de analfabetismo no Brasil foram de $10 \%$ para os homens e $6 \%$ para as mulheres, 
enquanto que na Argentina e no Chile o analfabetismo atingia apenas $2 \%$ dos homens e $1 \%$ das mulheres.

Estimou-se um modelo lógite multinomial de trabalho e freqüência à escola para os jovens de modo a identificar os fatores que determinam a escolha dos jovens entre estudar, trabalhar, cuidar de afazeres domésticos, ou não realizar nenhuma atividade. Os resultados obtidos mostraram que a escolaridade e idade do chefe de família, o número de pessoas na família com 8 ou mais anos e a renda familiar foram as variáveis mais importantes na decisão de os jovens estudarem, independente de trabalharem ou não. Por outro lado, o aumento da idade do jovem e o maior número de crianças na família contribui para aumentar a probabilidade dos jovens trabalharem.

Também foram estimados modelos lógite multinomiais para entender as características que afetam a probabilidade de desemprego de um determinado indivíduo. Os resultados mostraram que a escolaridade e a experiência são variáveis muito importantes para explicar o desemprego. Encontrou-se fortes indícios de existência de discriminação racial contra os negros, uma vez que obteve-se probabilidades maiores de desemprego para os pretos em relação aos brancos e pardos, mantendo-se outras variáveis constantes. Verificou-se também que a probabilidade de desemprego é maior para o jovem cuja renda familiar é mais baixa.

Os dados indicaram que os jovens enfrentam graves problemas em termos de dificuldades de conciliação do estudo com o trabalho, baixos níveis de escolaridade, altas taxas de desemprego, relações de contratação precárias, jornadas extensas de trabalho e baixos rendimentos.

Essa situação tende a se agravar com a perspectiva de pequeno crescimento da economia e da incapacidade das empresas gerarem postos de trabalho suficientes e de boa qualidade para absorver e dar oportunidade a todos aqueles que necessitam e têm disponibilidade para trabalhar. Assim, algumas medidas poderiam ser tomadas no sentido de melhorar a situação do jovem no mercado de trabalho. Medidas específicas voltadas para os jovens seriam: atuar na questão educacional, com o objetivo de 
melhorar o nível de escolaridade e capacitação profissional tendo por condicionante a necessidade de compatibilizar estudo e trabalho, a regulamentação de estágios, a criação de programas de treinamento e a criação de cursos profissionalizantes de $2^{\circ}$ grau. No plano macroeconômico é necessário criar condições para que o setor produtivo gere postos de trabalho suficientes, e um passo nessa direção é a adoção de medidas que diminuam o alto grau de concentração de renda do país, pois tal medida, possibilita a uma grande parcela da população pobre aumentar o consumo de bens, aumentando assim, a produção e, consequentemente o nível de emprego. Por outro lado, uma melhor distribuição da renda pode retirar do mercado de trabalho uma grande parte de crianças, jovens e aposentados que só estão mabalhando por extrema necessidade. 


\title{
BRAZILIAN YOUTH: THE CONFLICT BETWEEN STUDY AND WORK AND THE UNEMPLOYMENT CRISIS
}

\author{
Author: NANCY DE DEUS VIEIRA SILVA \\ Adviser: Prof. Dr. ANA LUCIA KASSOUF
}

\section{SUMMARY}

In 1998 there were over 31 million youngsters aged 15-24 in Brazil, corresponding to $19.5 \%$ of the total population. The objective of this study is to investigate the situation of these youngsters in the labor market. It is an effort to recognize their social-economic conditions, particularly the educational level, as well as to evaluate the magnitude and determinants of unemployment of Brazilian youth. Microdata provided by 1998's National Household Survey (PNAD) have been used.

The introduction of youth into the labor market takes place in a quite unfavorable manner. Firstly, the access of youngsters into the laboring world is very precocious, with a great number of them having their first job at the age of 12 or below. Unemployment affects 3.3 million youngsters, representing $49 \%$ of the total Brazilian unemployed. Most of them work at the informal labor market (65\%) and a great deal works over 44 weekly hours, as required by the legislation. In addition, the earnings are very low, approximately $50 \%$ of the eamings of an adult, on average.

These youngsters are still in school age and have to divide their time between study and work. The problems faced by them in the labor market interfere directly in their education. Although the educational profile of Brazilian youth has improved, this indicator is still very low in comparison with other countries. The education of young Brazilians was of 6.7 years, on average, while in Argentina it was 9.2, in Uruguay 8.1 and in Chile 7.8. Moreover, the illiteracy rates in Brazil were 10\% for men and $6 \%$ for women, while in Argentina and Chile the illiteracy reached only $2 \%$ of men and $1 \%$ of women. 
A multinomial logit model of work and school attendance for youngsters was estimated so as to identify the factors determining the choice of youngsters between studying, working, housekeeping, or performing no activities at all. The results showed that the education and age of the head of the family, number of people in the family aged 8 or above and family income were the most important variables in the youth's decision towards studying, regardless of actually working or not. On the other hand, the increase of the youth's age and higher number of children in the family accounts for an increased probability of the youngster to work.

Also multinomial logit models were estimated to understand the characteristics affecting the unemployment probability of a given individual. The results showed that the education and experience are very important variables to explain unemployment. Strong indications of racial discrimination against blacks were observed, since there were more unemployment probabilities for the blacks in relationship with the white and "parda" people, others variables constant. The unemployment probability was also verified to be higher for lower youth's income family.

The data indicated that the youth face serious problems concerning difficulties of reconciling study and work, low education levels, high unemployment rates, precarious hiring relationships, long work hours and low income.

This situation tends to aggravate with the perspective of a low economy growth and inability of enterprises to generate enough and good quality jobs in order to absorb and provide opportunities to all that need. Them, some actions could be taken to improve the youth's condition in the labor market. Specific measures focusing the youth could be: to improve the education level and training, making study and work compatible, job training regulations, creation of training programs and professionalizing $2^{\text {nd }}$ grade courses. At a macroeconomic scope conditions must be created so that the productive sector can generate enough jobs. The adoption of measures decreasing the high level of the country's income inequality could be an effort towards it, because it would increase the consumption for the low income group of the population, increasing 
therefore the production and consequently the employment. The income distribution could then decrease the number of children, youth and elderly working. 


\section{INTRODUÇÃO}

A população jovem brasileira representou cerca de $20 \%$ da população total na década de 90. Apesar de sua alta representatividade na população, pouco se sabe sobre a situação do jovem no mercado de trabalho. A Pesquisa Nacional por Amostra de Domicílios (PNAD) de 1998 possibilita uma análise detalhada das condições sócioeconômicas dos jovens brasileiros. Com base nestes dados é possível realizar um diagnóstico da situação do jovem, com idade entre 15 e 24 anos, no mercado de trabalho brasileiro.

De acordo com relatório produzido pela OIT (2000), o tamanho da população jovem, com idade entre 15 e 24 anos, com relação à população adulta, com idade entre 25 e 54 anos, tem diminuído em todos os países desenvolvidos e na maior parte dos países em desenvolvimento. No Brasil, em 1990, a população jovem representava 45,9\% da população adulta, já em 1996 essa porcentagem diminuiu para $39,1 \%$ (OIT, 2000 - Tabela 1).

Do ponto de vista econômico, há evidências de que a educação contribui significativamente para elevar a produtividade dos trabalhadores e consequentemente para o desenvolvimento do país. É amplamente conhecido que a população brasileira possui baixo nível de escolaridade. A partir de dados da PNAD de 1998 verificou-se que $62,8 \%$ das pessoas de 15 anos ou mais não tinha completado o ensino fundamental, ou seja, a escolaridade mínima constitucionalmente obrigatória (oito anos de estudo). Pior ainda, 33,4\% da população de 10 anos ou mais não havia alcançado sequer a obrigatoriedade escolar estabelecida pela constituição de 1934, pois tinham apenas até 
3 anos de estudo; portanto, menos que a escola primária. A escolaridade média para a população de 15 anos ou mais, em 1998, era de 5,9 anos.

Os dados da PNAD revelaram que o nível de escolaridade da população jovem, com idade entre 15 e 24, é um pouco melhor, mas também é insatisfatório, sendo a escolaridade média, em 1998, de 6,7 anos. Mais da metade dos jovens brasileiros não tinha completado o ensino fundamental $(55,4 \%)$ e $17,5 \%$ não havia sequer completado a escola primária. Apenas $17 \%$ havia completado o $2^{\circ}$ grau e somente $1 \%$ concluído curso de nível superior. Ademais, vale ressaltar que entre os jovens existia, em 1998, $5,6 \%$ sem instrução alguma ou com menos de um ano de estudo. Portanto, tinha-se em 1998 uma população jovem carente de educação formal, o que certamente prejudica sua inserção no mercado de trabalho, bem como sua produtividade.

A baixa escolaridade da população brasileira pode estar diretamente relacionada ao trabalho dos jovens. A maioria deles procura trabalho por necessidade de sobrevivência e outros por busca de independência financeira, sendo em muitos casos o trabalho incompatível com a freqüência escolar, o que por sua vez leva à escolha do trabalho em prejuízo à escola. Portanto, conforme dito por Leme e Wajnman (2000), a escolaridade pode ser vista como resultado do processo de decisão das familias sobre a alocação do tempo de seus membros mais jovens, e as escolhas (não-excludentes) de estudar e/ou trabalhar tornam-se cruciais à medida que os jovens vão alcançando idades compatíveis com a atividade econômica. Desta forma, os jovens enfrentam o problema de escolher entre o trabalho e o estudo ou conciliar ambos, visto que o trabalho passa a ser uma opção bastante atrativa para os jovens de 15 e 24 anos e, estes só completam o primeiro grau, segundo grau e o curso superior aos 15, 18, 23 ou mais anos de idade, respectivamente.

Os jovens representam uma fração significativa da mão-de-obra brasileira. A análise dos dados da PNAD de 1998 mostrou que 63\% com idade entre 15 e 24 anos fazia parte da PEA - população economicamente ativa, representando $25 \%$ da PEA brasileira. Entretanto, os jovens possuem uma posição frágil no mercado de trabalho. 
Estes freqüentemente são encontrados nos piores postos de trabalho, isto é, no mercado de trabalho informal, onde são mal remunerados e desprotegidos pela lei, além das precárias condições de trabalho, que são características inerentes ao setor. Além disso, pouco se sabe sobre os jovens no mercado de trabalho brasileiro, e praticamente inexistem estudos empíricos sobre este segmento da população.

$\mathrm{O}$ aumento das taxas de desemprego tem preocupado todas as nações ao redor do mundo, trata-se de um grave problema social que vêm afetando economias desenvolvidas e em desenvolvimento. Entretanto, no Brasil o assunto é ainda pouco explorado. Tal situação é em grande parte observada devido às baixas taxas de desemprego aberto ${ }^{1}$ divulgadas pelo $\mathrm{IBGE}$, bem como em função da crença de que a precariedade do emprego é um fator muito mais importante para explicar os altos graus de pobreza e desigualdade no país do que propriamente a falta de empregos.

A taxa de desemprego no Brasil situava-se em 1997 em patamares relativamente baixos (5,7\%) em comparação com outros países, especialmente Espanha (20,6\%), Argentina (16,3\%) $)^{2}$, Polônia (11,2\%), França (12,3\%) e Itália (12,1\%). A taxa de desemprego no Brasil é mais próxima da dos Estados Unidos (4,9\%), Coréia $(2,6 \%)$ e Japão $(3,4 \%)^{3}$. Esta baixa taxa de desemprego, comparativamente aos níveis observados internacionalmente, coexiste com elevada taxa de informalidade na economia brasileira, onde mais da metade da força de trabalho ocupada é formada por empregados sem carteira de trabalho assinada. Segundo Urani (1996), uma das possíveis explicações para a taxa de desemprego ter se mantido relativamente baixa nos últimos anos pode estar na capacidade dos segmentos informais do mercado de trabalho absorverem eventuais excessos de mão-de-obra do segmento formal.

\footnotetext{
${ }^{1}$ Pessoas que procuraram trabalho de maneira efetiva nos últimos 30 dias anteriores ao da entrevista e não exerceram nenhum trabalho nos últimos sete dias.

${ }^{2}$ Este valor é referente a 1996.

${ }^{3}$ Estes valores foram retirados de OIT (2000), Tabela 2, exceto para o Brasil, pois o último valor para o país era de 1996, constando na fonte citada. O dado do Brasil foi coletado junto à Revista Conjuntura Econômica (FGV) - março de 2000. A taxa de desemprego no Brasil e Argentina é considerada para população com 10 ou mais anos de idade, para Espanha e Estados Unidos é considerada população com idade acima de 16 anos e demais países a idade considerada é acima de 15 anos.
} 
Apesar da taxa de desemprego ser relativamente baixa no Brasil ela apresenta-se elevada para determinados subgrupos populacionais, sendo principalmente diferenciada por sexo e idade: mais alta para as mulheres e para os jovens. Isso pode significar que o problema do desemprego pode estar restrito a certos grupos demográficos. Conforme dados da PNAD de 1998 a taxa de desemprego ${ }^{4}$, para população com 10 ou mais anos de idade, entre os homens foi de 7,2\% e entre as mulheres foi de 11,6\%. Da mesma forma, a taxa de desemprego dos trabalhadores com idade entre 25 e 64 anos foi de $6,1 \%$, enquanto a taxa de desemprego dos jovens, com idade entre 15 e 24 anos, atingiu 17,2\%.

De acordo com a OIT (2000), as taxas de desemprego entre os jovens são relativamente mais altas na década de 90 quando comparadas com a década de 80 , sendo aproximadamente duas vezes a taxa de desemprego entre os adultos com idade entre 25 a 64 anos.

Segundo Koreman e Neimark (1997), entre as economias desenvolvidas, os países da Europa enfrentam uma crise de emprego entre os jovens. No período de 19701994 a taxa média de desemprego entre os jovens com idade entre 15 e 24, nos 11 países europeus estudados pelos autores, aumentou 16 pontos percentuais (de 4,2 para 20,6\%), enquanto a taxa média do desemprego entre os adultos com idade entre 25 e 54 anos aumentou de 1,6 para 9,7\%. Ainda segundo os autores, nos Estados Unidos, no mesmo período, a taxa de desemprego entre os jovens aumentou de 11,0 para 12,5\%, e entre os adultos aumentou de 3,4 para 5\%. Para este mesmo período, a média da taxa de emprego dos jovens nos 11 países europeus caiu de $59 \%$ para $41 \%$, enquanto o emprego entre os adultos aumentou ou permaneceu estável.

Na década de 90, o mercado de trabalho brasileiro apresentou uma queda do emprego formal em termos absolutos e um aumento do emprego informal. Ao mesmo tempo, vem se observando uma geração insuficiente de postos de trabalho, mesmo que

\footnotetext{
${ }^{4}$ São consideradas desempregadas as pessoas sem trabalho que tomaram alguma providência efetiva de procura por rabalho na semana de referência de 20 a 26 de setembro de 1998.
} 
informais e precários. Esta combinação de tendências" tem tido impacto negativo sobre praticamente todas as faixas da força de trabalho. Porém, o efeito é pior sobre os grupos mais vulneráveis, particularmente jovens, idosos e mulheres.

No Brasil as taxas de desemprego entre os jovens de 15 a 24 anos de idade aumentaram substancialmente no período de 1990 a 1998. Em 1990 existia 10,7\% de jovens desempregados, enquanto em 1998 essa mesma porcentagem eleva-se para $17,2 \%$. Os jovens de 15 a 24 anos representavam $51 \%$ e $49 \%$ dos desempregados brasileiros em 1990 e 1998, respectivamente (PNAD, 1990 e 1998).

Pela Constituição Brasileira de 1988, a idade mínima para admissão no mercado de trabalho era de 14 anos. Em dezembro de 1998 foi aprovada uma emenda que fixa em 16 anos a idade mínima para admissão no trabalho. A nova lei que estabelece 16 anos como a idade mínima de trabalho diminuiu, provavelmente, a demanda por trabalho, mas não alterou as necessidades de emprego nem o quadro nacional de educação e formação profissionalizante. O único efeito da lei sobre as empresas é restringir a contratação de jovens com 14 e 15 anos, os quais podiam ser contratados legalmente pelas empresas antes da lei ser alterada. Deste modo, a nova lei, na conjuntura econômica atual, pode aumentar o trabalho informal clandestino de jovens, tendo implicações mais amplas ainda não avaliadas para o mercado de trabalho e para a educação e formação profissionalizante.

Este estudo tem por objetivo diagnosticar a situação do jovem, com idade entre 15 e 24 anos, no mercado de trabalho brasileiro. Busca conhecer as condições sócio-econômicas dos jovens trabalhadores, particularmente seu nível educacional, bem como avaliar a magnitude e os determinantes do desemprego da juventude brasileira.

A decisão de o jovem trabalhar e/ou estudar é função de diversas variáveis, dentre elas destacam-se: sexo, idade, cor, área de residência (urbana ou rural), número de membros na família com sete anos ou menos de idade, número de membros na família com oito ou mais anos de idade, escolaridade, idade e sexo do chefe de família, renda familiar per capita e região de residência. Todas essas variáveis são mensuráveis e 
disponíveis para análise. A partir dessas variáveis busca-se identificar os determinantes da decisão de alocação do tempo entre seis alternativas: só estudar, só trabalhar, estudar e trabalhar, estudar e cuidar de afazeres domésticos, só cuidar de afazeres domésticos e não estudar nem trabalhar.

\subsection{Importância do problema e justificativas}

O trabalho e a escolaridade dos jovens estão intimamente relacionados, ou seja, o trabalho do jovem afeta sua escolaridade e vice-versa, sendo que a tomada de decisão de os jovens ofertar ou não o seu trabalho deverá estar relacionada com a decisão de estudar ou não. Existem poucos trabalhos que analisam a alocação do tempo dos jovens entre trabalho e estudo, geralmente as pesquisas focalizam a freqüência à escola ou a alocação do tempo para o trabalho. Portanto, a contribuição deste trabalho será analisar a tomada de decisão dos indivíduos considerando um maior número de opções, as quais são: somente estudar, trabalhar e estudar, somente trabalhar, estudar e cuidar de afazeres domésticos, só cuidar de afazeres domésticos e não trabalhar nem estudar, buscando identificar os determinantes da escolha dos jovens quanto à alocação de seu tempo. Ademais, a pesquisa dirige-se a um segmento populacional (jovens de 15 a 24 anos) sobre o qual praticamente não existem estudos sócio-econômicos.

Analisar a questão do emprego e sua qualidade é por si só um tema relevante para estudos acadêmicos, particularmente a questão do desemprego entre os jovens, devido a sua magnitude e futuras conseqüências na vida destes indivíduos e para o desenvolvimento econômico do país. Entretanto, estudos sócio-econômicos a respeito do mercado de trabalho de jovens são praticamente inexistentes no Brasil, enquanto na literatura internacional observa-se que o tema é amplamente debatido, principalmente nos países industrializados.

O desemprego entre a população jovem brasileira atinge níveis alarmantes, com $17,2 \%$ desta população estando desempregada em 1998, correspondendo a $49 \%$ do total dos desempregados brasileiros. O desemprego é um dos principais problemas enfrentados pelos jovens, senão o principal, pois existe no país um elevado número de 
jovens que necessitam trabalhar para sobreviver. Isso associado com a inadequação dos sistemas de educação diante das exigências do mercado de trabalho elou com a incapacidade de muitos jovens permanecerem na escola leva a uma falta de perspectivas por parte destes jovens, o que provoca uma série de problemas sociais como o aumento do consumo de álcool e drogas, aumento da violência e da prostituição e altas taxas de gravidez precoce. Ademais, as empresas têm valorizado a experiência dos trabalhadores para sua contratação, sendo este mais um obstáculo enfrentado pelos jovens para a obtenção de um lugar no mercado de trabalho, especialmente para a obtenção de seu primeiro emprego.

O processo de "exclusão juvenil" do mercado de trabalho em expansão compromete o desempenho sócio-econômico futuro destes jovens, bem como o desenvolvimento econômico do país, tornando necessária a compreensão deste fenômeno, com vistas a viabilizar a integração social e econômica dos jovens.

\subsection{Objetivos}

O presente trabalho visa ratar a problemática do jovem no mercado de trabalho utilizando-se de dados recentes, mais especificamente da Pesquisa Nacional por Amostra de Domicílios (PNAD) de 1998, que permitem traçar o perfil dos jovens brasileiros. Quem são? Qual sua situação no mercado de trabalho? Qual seu nível de escolaridade? Estas e outras questões serão analisadas no decorrer do trabalho tendo em vista a condição de atividade dos jovens (economicamente ativos ou inativos), sendo os ativos divididos em ocupados e desocupados ${ }^{5}$.

Especificamente pretende-se:

${ }^{5}$ São classificados pela PNAD como ocupados todos aqueles que trabalharam ou tinham trabalho na semana de referência da pesquisa ( 20 a 26 de setembro). Como desempregados são classificados os indivíduos que não tinham trabalho, mas que procuraram pelo mesmo na semana de referência ( 20 a 26 de setembro). Os demais indivíduos foram classificados como inativos, ou seja, as pessoas que não foram classificadas como ocupadas nem desempregadas nesse período. 
a) Descrever detalhadamente a situação vigente em 1998 em termos da condição de atividade e de ocupação dos jovens, bem como verificar a porcentagem de jovens que frequientavam unidade escolar, ofertavam trabalho, cuidavam de afazeres domésticos, conciliavam trabalho ou afazeres domésticos com estudo ou não realizavam nenhuma dessas atividades.

b) Verificar quem são os jovens que trabalham no Brasil, o que eles fazem como ocupação habitual, qual a intensidade de seu trabalho, quanto ganham e qual a contribuição dos jovens na formação da renda familiar.

c) Verificar se a participação do jovem no mercado de trabalho faz parte de uma estratégia de sobrevivência familiar ou se faz parte da busca de autonomia, autoafirmação e independência financeira.

d) Identificar os determinantes da decisão de alocação de tempo dos jovens entre seis possíveis formas: a) só estudar, b) só trabalhar, c) estudar e trabalhar, d) estudar e cuidar de afazeres domésticos, e) só cuidar de afazeres domésticos, ou f) não estudar nem trabalhar; visando captar a relação entre a freqüência à escola e o trabalho dos jovens.

e) Verificar quem são os jovens desempregados no Brasil e analisar a estrutura do desemprego entre estes, ou seja, verificar como o desemprego se distribui entre os diversos grupos sociais em que se pode dividir a população jovem economicamente ativa. A análise se dará ao longo das seguintes dimensões: situação de domicílio (urbano e rural), região de residência, gênero, nível educacional, cor, idade e posição na familia.

f) verificar algumas características que afetam a probabilidade de um determinado jovem se encontrar desempregado em um determinado instante do tempo.

Serão feitas análises separadas para homens e mulheres das áreas urbanas e rurais do Brasil, visando verificar como as probabilidades de inatividade, emprego e 
desemprego, e do jovem se encontrar em uma das seguintes situações: só estuda, estuda e trabalha, não estuda e trabalha, estuda e cuida de afazeres domésticos, só cuida de afazeres domésticos e não estuda nem trabalha, variam entre os jovens com diferentes características de idade, experiência, nível de escolaridade, escolaridade, idade e sexo do chefe de família, cor, região de residência, gênero, renda familiar per capita, número de elementos na família por faixa etária e posição na família.

Para atingir tais objetivos será utilizado o modelo lógite multinomial na estimação das equações de trabalho e frequiência à escola e das equações de inatividade e desemprego. Neste modelo o tomador de decisão considera todas as alternativas disponíveis simultaneamente antes de tomar a decisão. No modelo lógite multinomial a variável dependente assume valores discretos, os quais representam as opções colocadas aos indivíduos, ou seja, a variável dependente, neste caso, tomará valor 0 se o indivíduo só estuda, 1 se o indivíduo só trabalha, 2 se o indivíduo estuda e cuida de afazeres domésticos, 3 se o indivíduo estuda e trabalha, 4 se o indivíduo só cuida de afazeres domésticos e 5 se o indivíduo não trabalha nem estuda.

Nas equações de inatividade, emprego e desemprego a variável dependente tomará o valor 0 se o indivíduo é inativo, 1 se o indivíduo é ativo e empregado e 2 se o indivíduo é ativo e desempregado.

\subsection{Organização deste estudo}

Este estudo está organizado em sete capítulos. No capítulo 1 são apresentadas informações gerais sobre o tema em questão, a importância e justificativa do problema e os objetivos. No capítulo 2 apresenta-se a revisão de literatura, onde são apresentados diversos estudos passados acerca do tema, cobrindo estudos realizados sobre o Brasil e outros países. No capítulo 3 são apresentados os dados utilizados na análise. O capítulo 4 apresenta a análise descritiva da amostra, a qual poderá auxiliar e dar suporte à análise dos resultados econométricos. O capítulo 5 descreve a metodologia empregada na análise econométrica dos dados e o modelo de respostas qualitativas, isto 
é, o modelo lógite multinomial, também são apresentadas as descrições das variáveis empregadas neste estudo. No capítulo 6 são apresentados e discutidos os resultados obtidos dos modelos econométricos - equações de alocação do tempo para jovens e equações de inatividade, emprego e desemprego, comparando-se os resultados obtidos para homens e mulheres e por situação de domicílio (urbano e rural). O capítulo 7 apresenta as conclusões do trabalho. 


\section{REVISÃO DE LITERATURA}

A situação sócio-econômica dos jovens nos países desenvolvidos é objeto de estudos nas diversas áreas do conhecimento, sendo que a grande maioria trata da problemática da inserção do jovem no mercado de trabalho e a tendência de sua exclusão social no mercado de trabalho. Entretanto, estudos sócio-econômicos a respeito do mercado de trabalho de jovens são praticamente inexistentes no Brasil, com exceção dos trabalhos de Camarano (2000), Leme e Wajnman (2000), Pochamann (1998) e Zylberstajn (1985).

A participação dos jovens na força de trabalho é bastante alta no Brasil quando comparada a países com background econômico similar. A posição relativa do Brasil, em 1995, pode ser identificada na Figura 1. Na Argentina e no Chile, países com renda per capita semelhante à do Brasil, os jovens possuem taxa de atividade bastante inferiores às verificadas no Brasil, principalmente para a faixa etária dos 15 aos 19 anos de idade.

Observa-se na Figura 1 que a taxa de atividade dos jovens brasileiros com idade entre 15 e 19 anos é de $69 \%$ e $43 \%$, para homens e mulheres, respectivamente, enquanto a do Chile é de $31 \%$ e $18 \%$ e da Argentina, de $55 \%$ e $24 \%$. Entre os jovens com idade entre 20 e 24 anos a diferença de taxas de atividade entre os três países não é tão significativa, sendo inclusive a taxa de atividade das mulheres argentinas superior à das mulheres brasileiras, a maior diferença ocorre entre o Brasil e o Chile, sendo que a taxa de atividade dos jovens brasileiros é 10 pontos percentuais superior à chilena. 


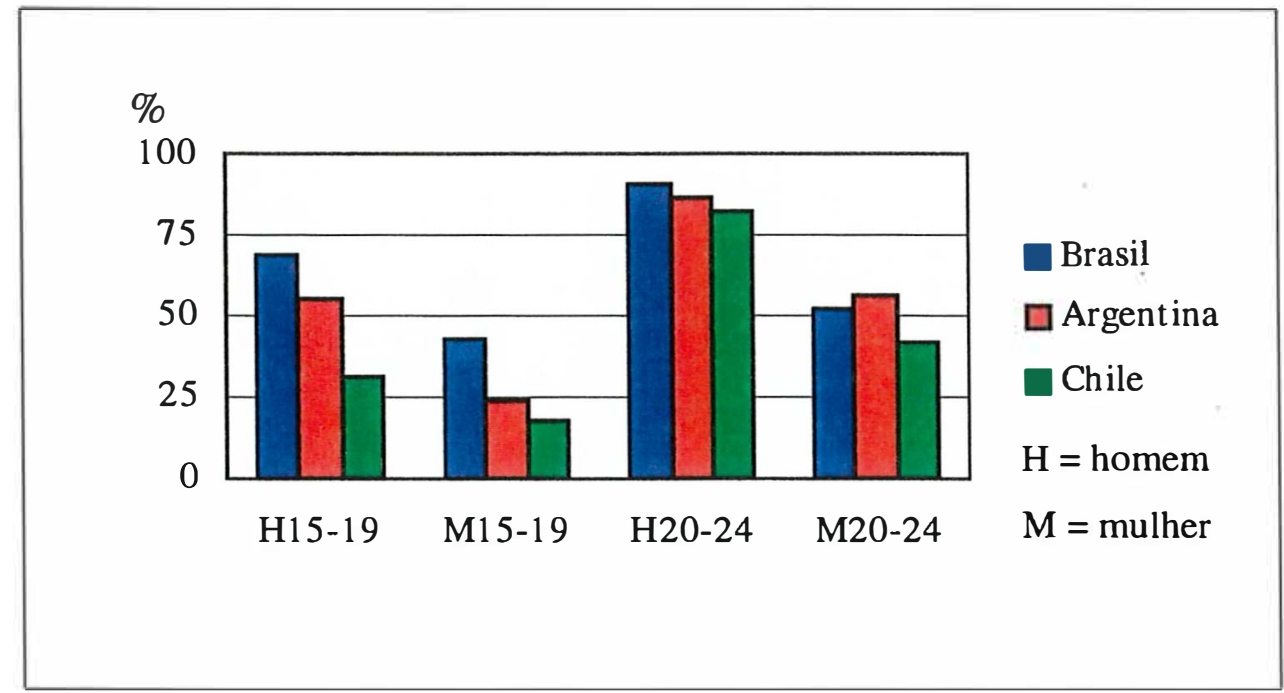

Figura 1 - Proporção de jovens economicamente ativos, em 1995, estratificados por sexo e faixa etária, 15 a 19 e 20 a 24 anos (Fonte: OIT, 2000 - Tabela 1).

Uma consequiência da elevada taxa de atividade dos jovens no Brasil é o baixo nível de escolaridade de sua população, mesmo para a geração mais nova. Embora o perfil educacional dos jovens brasileiros tenha melhorado, ao longo dos últimos anos, esse indicador ainda é baixo, mesmo quando comparado com outros países da América Latina. Em média, a escolaridade dos jovens de 15 a 24 anos de idade no Brasil, em 1998, era de 6,7 anos, enquanto na Argentina era de 9,2, no Uruguai de 8,1 e no Chile de 7,8. Ademais, dados do Banco Mundial (2001) mostram que o Brasil tem a maior taxa de analfabetismo da América Latina. Conforme se pode verificar na Figura 2, em 1999, no Brasil, $10 \%$ dos homens e $6 \%$ das mulheres de 15 a 24 anos não tinha condições de entender, ler ou escrever um texto pequeno e simples, enquanto que na Argentina e no Chile o analfabetismo atingia apenas $2 \%$ dos homens e $1 \%$ das mulheres. 


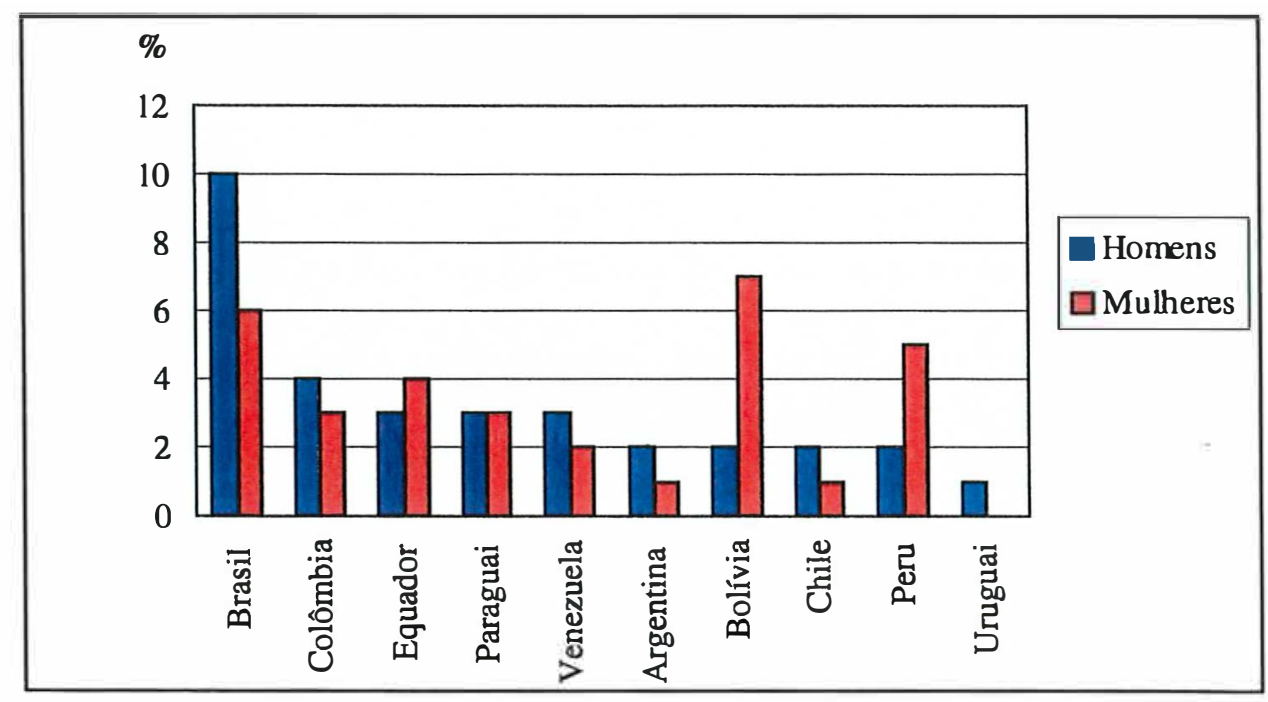

Figura 2 - Taxas de analfabetismo para alguns países da América Latina em 1999 (Fonte: Banco Mundial, 2001).

Corseuil et al. (2001) investigaram os determinantes da alocação do tempo dos jovens em quatro países latino-americanos: Brasil, Chile, Honduras e Peru. Verificaram que a educação dos pais tem forte efeito de aumentar a probabilidade de os jovens se dedicarem ao estudo na medida em que se considera pais mais educados. Também constataram que o grau de urbanização, o número de crianças e o número de idosos exerce grande efeito nas escolhas dos jovens quanto à alocação de seu tempo.

Menezes-Filho et al. (2000) analisaram os determinantes da alocação do tempo dos jovens de 12 a 19 anos para 17 países Latino Americanos, usando dados da Inter-American Development Bank - DB. Verificaram que a escolaridade dos pais é o principal determinante das decisões de alocação de tempo dos jovens. Outros importantes fatores determinantes encontrados foram renda familiar e o número de irmãos mais novos. As principais variáveis macroeconômicas correlacionadas com a alocação de tempo dos jovens foram o PIB per capita e as taxas de desemprego dos jovens.

Leme e Wajnman (2000), a partir de dados da PNAD de 1998, realizaram estudo a respeito da alocação do tempo dos jovens e adolescentes brasileiros (10 a 19 anos de idade) entre o trabalho e a escola. Neste trabalho as autoras encontraram taxa de 
participação na força de trabalho dos jovens brasileiros (15 a 19 anos) de 53\% em 1998, constatando ainda, que a proporção dos jovens que trabalham e estudam no Brasil é uma das mais altas do continente.

As autoras analisaram a evolução da taxa de participação na força de trabalho dos jovens brasileiros para o período de 1981 a 1998. Para os jovens com idade entre 15 e 19 anos, a taxa de participação esteve todo o período acima de 53\%, atingindo um pico de $60 \%$ em 1992 e estabilizando-se a seguir em pouco mais de $50 \%$.

Em relação à frequiência escolar as autoras verificaram que a porcentagem de jovens que freqüenta a escola cresceu sistematicamente no período analisado, passando de $46 \%$ para $66 \%$ para os jovens com idade entre 15 e 19 anos de idade. Observaram ainda que o aumento na taxa de freqüência à escola foi generalizado, mas ocorreu principalmente para os jovens na faixa de 15 a 17 anos de idade.

A pesquisa ainda separou os jovens em quatro grupos: a) apenas estudam, b) apenas trabalham, c) fazem ambas as coisas e d) não fazem nenhuma das duas. Na faixa de 15 a 19 anos de idade a proporção de jovens que apenas estudam aumenta de 30\% para $36 \%$ e a dos que trabalham e estudam se eleva de $16 \%$ para $30 \%$, no período de 1981 a 1998.

As autoras complementam essa análise separando os dados por nível de renda, tendo dividido a amostra em 10 decis de renda. Para os jovens de 15 a 19 anos de idade na faixa de renda mais baixa, a porcentagem de jovens estudando sobe de $28 \%$ para $43 \%$, sendo que o resultado é basicamente fruto do aumento dos que trabalham e estudam e diminuição dos que apenas trabalham. Nesta faixa de idade, apesar da redução, é ainda elevada a porcentagem de jovens que só trabalham, e a porcentagem dos que nem trabalham nem estudam se manteve constante - em torno de $18 \%$, índice este considerado bastante elevado. No $10^{\circ}$ decil, faixa de renda mais alta, foi observado aumento na categoria só estuda, que passa de $55 \%$ para $65 \%$, enquanto a categoria trabalha e estuda aumenta de $18 \%$ para $24 \%$. Na comparação de todos os decis observase que a fração dos jovens que apenas estudam aumenta com a renda. A porcentagem de 
jovens que trabalham e estudam não apresenta comportamento monótono com a renda, tendo se apresentado mais baixa nos decis extremos, comportamento este não esperado. A porcentagem de jovens que só trabalham é maior entre os mais pobres, enquanto não estudar nem trabalhar atingem igualmente os jovens nos cinco primeiros decis de renda.

Camarano (2000) procurou investigar as condições de vida da população jovem brasileira, faixa etária dos 18 aos 24 anos, utilizando-se de dados da Pesquisa Nacional por Amostra de domicilios (PNAD) de 1998. Segundo a autora, apenas 14,2\% destes jovens tinham terminado o segundo grau e 3,7\% o curso superior. Sua análise mostrou que grande parte dos jovens brasileiros já havia ingressado na vida adulta, pois, $53 \%$ destes jovens estava no mercado de trabalho. Considerando apenas a população masculina, essa proporção eleva-se para $65 \%$, enquanto para o grupo feminino decresce a $40 \%$. Ademais, $21,5 \%$ dos homens jovens eram chefes de família e $39 \%$ das mulheres já tinham se tornado mães. Zylberstajn (1985), analisando dados da PNAD de 1976, verificou que um em cada dois jovens de 15 a 17 anos trabalhava e $80 \%$ dos jovens de 18 a 24 anos já havia ingressado no mercado de trabalho. Portanto, pode-se constatar que a grande participação dos jovens brasileiros no mercado de trabalho não é um fenômeno recente.

De acordo com Amadeo (1998) está ocorrendo no Brasil, desde 1994, uma queda substancial da oferta de trabalho entre os jovens de 15 a 24 anos de idade. A taxa de participação nesta faixa etária caiu de 54\% para 51\% da população entre 1994 e 1998. Tal fato pode estar refletindo a "atratividade" do mercado em relação a outras alternativas ou pode estar indicando que mais jovens deixaram de procurar emprego devido à sua escassez e, consequentemente, dificuldade de inserção no mercado de trabalho. Uma hipótese otimista é que o jovem pode estar preferindo ficar mais tempo na escola ao invés de entrar no mercado de trabalho cedo, ou a família pode estar conseguindo mantê-los fora do mercado de trabalho, incentivando-os a apenas estudar.

Segundo Pochmann (1998) a oferta de mão-de-obra juvenil, formada por pessoas na faixa etária entre 10 e 24 anos, vem decrescendo ao longo das duas últimas 
décadas. Em 1996, a força de trabalho juvenil representava 29,6\% da PEA total, ao passo que em 1989 constituía 33,2\% do total. Segundo o autor, a redução da participação relativa dos jovens no total da PEA nos anos 90 reflete, por um lado, o fenômeno demográfico de estabilização, ou mesmo a redução da taxa de participação para determinadas faixas etárias masculinas mais jovens. Em contrapartida, expressa também a elevação relativa do peso da PEA feminina, cujo processo é constatado por diversas pesquisas.

Segundo relatório produzido pela OIT (2000), os jovens em circunstâncias de alto desemprego permanecem mais tempo na escola. Dentro dos países desenvolvidos está ocorrendo um incremento substancial na proporção de jovens que dedicam tempo integral ao estudo, um aumento moderado na proporção de jovens que combinam escola e trabalho, uma forte queda na proporção de jovens que apenas trabalham e uma ligeira queda na proporção de jovens que não estudam e nem trabalham.

De acordo com Camarano (2000), em 1998, aproximadamente 50\% da população jovem masculina apenas trabalhava, 16\% apenas estudava, 16\% estudava e trabalhava e $18 \%$ não realizava nenhuma dessas atividades. A maior parte das mulheres jovens não estudava nem trabalhava (40\%), $27 \%$ só trabalhava, $20 \%$ só estudava e $13 \%$ estudava e trabalhava. Aproximadamente 32\% dos jovens brasileiros, com idade entre 18 e 24 anos, freqüentavam a escola, sendo que aos 18 anos essa proporção era de $56 \%$ e aos 24 anos era de apenas $16 \%$.

Dustmann et al. (1997) analisaram alguns aspectos da participação de jovens de 16 e 17 anos no mercado de trabalho. O estudo foi feito para a Inglaterra e utilizaram dados da National Child Development Study. Verificaram que a renda familiar não tem efeito sobre a participação dos jovens no mercado de trabalho e que a educação e desemprego dos pais tem efeito negativo na oferta de trabalho dos jovens em tempo parcial. Este último resultado deve-se, provavelmente, ao fato de que pais desempregados têm menos informações e contados com os empregadores. Verificaram 
ainda que o trabalho em tempo parcial dos jovens aumenta significativamente a evasão escolar.

Segundo Camarano (2000), as famílias nas quais os chefes são jovens são as mais pobres, apresentando menor número de pessoas que trabalham e proporção maior de renda que depende do chefe de família. Ademais, o trabalho de jovens é mais freqüente em famílias grandes, com sete ou mais membros, e em famílias de baixa renda. Conforme verificado por Zylberstajn (1985), no Brasil em 1980, 33\% das famílias pobres eram grandes, mas entre as famílias pobres que usavam o trabalho de jovens e menores essa proporção era de $67 \%$.

O trabalho dos jovens, principalmente para aqueles com idade entre 15 e 17 anos, está intimamente relacionado à renda familiar. Segundo PNUD (1996), em 1990 a taxa de atividade dos jovens que viviam em famílias pobres (até meio salário mínimo per capita) atingia 54\%, contra $30 \%$ dos jovens com renda familiar per capita superior a dois salários mínimos. Ainda de acordo com o relatório, a pobreza não pode ser considerada a única explicação para o trabalho dos jovens nesta faixa etária, sendo comum para estes, a necessidade de auto-afirmação e de independência da família, para alguns isto significa a busca de uma fonte de renda a partir do trabalho.

Camarano (2000) verificou que a grande maioria dos jovens ocupados era formada pela categoria de empregados, e destes, $19 \%$ não possuíam carteira de trabalho assinada, sendo que a proporção de não jovens sem carteira foi de 7,7\%. Verificou ainda que a maioria dos jovens brasileiros encontra-se ocupados no setor terciário. Zyberstajn (1985) observou que entre os jovens com idade entre 15 e 17 anos, $24 \%$ deles trabalhavam na indústria, $21 \%$ no setor de serviços, $20 \%$ no comércio e $13 \%$ em atividades agrícolas, 7,9\% na indústria da construção e o restante em outras atividades. Daqueles com idade entre 18 e 24 anos, mais da metade encontrava-se no setor terciário, sendo $24 \%$ em atividades diversas, $14 \%$ em serviços e $16 \%$ no comércio, aproximadamente $25 \%$ na indústria e os demais em outras atividades. Nota-se, portanto, que a tendência de concentração dos jovens no setor de serviços é de longa data. 
Segundo OIT (2000), o tamanho da força de trabalho está caindo na agricultura e na indústria e aumentando no setor de serviços em todas as regiões em desenvolvimento, África do Norte, Ásia Ocidental, América Latina e Caribe. De 1980 a 1990 o setor de serviços absorveu todo o crescimento da força de trabalho jovem nos países desenvolvidos e, em torno de 50\% na África do Norte, América Latina, Caribe e Ásia Ocidental.

Blanchflower e Freeman (2000) observaram que, na maioria dos países industrializados, os jovens trabalham em setores econômicos distintos dos adultos. Os jovens são encontrados mais freqüentemente no comércio de varejo, hotéis e restaurantes que na administração pública e serviços de educação. Entre os homens, um número desproporcional de jovens é encontrado na construção civil e entre as mulheres, um número desproporcional de jovens é empregada no setor de saúde. Desta forma, diferenças na distribuição do emprego entre os setores da economia para trabalhadores jovens e adultos sugerem uma separação do mercado de trabalho para jovens e para adultos. Assim, o desempenho do mercado de trabalho para os jovens depende do desenvolvimento de um grupo limitado de setores da economia.

Swaminathan (1997) analisou a natureza das ocupações e condições de trabalho de jovens de 15 a 18 anos nas cidades de Bhavnagar e Gujarat, situadas na Índia. Verificaram que jovens que entram muito cedo na força de trabalho possuem jornadas de trabalho mais longas do que aqueles que começaram a trabalhar mais tarde. Ademais, estes jovens trabalhadores não recebem mais pelo maior número de horas trabalhadas, recebendo, muitas vezes, menos. Concluíram, portanto, que o trabalho precoce não está associado à aquisição de habilidades, experiência, learning by doing, especialização no trabalho ou outros fatores que contribuem para aumentar as possibilidades de melhores rendimentos no futuro.

O nível de rendimento da população jovem é significativamente menor que da população adulta, o que é em parte explicado pelo momento no ciclo de vida, embora se saiba que os jovens contribuem com grande parcela para a formação da renda 
familiar. Em 1998, segundo Camarano (2000), a contribuição da renda dos jovens à renda familiar em que vivem alcançou, em média, 26\%. Gouveia (1982), citado por Zylberstajn (1985), verificou que $32 \%$ das familias brasileiras em 1980 compunham sua renda com rendimentos de indivíduos não disponíveis ${ }^{6}$, total ou parcialmente, sendo que em $11 \%$ das famílias a renda era formada exclusivamente por estes membros. Ademais, segundo este autor, as famílias pobres, com renda per capita inferior a $1 / 4$ do salário mínimo, cuja renda era formada predominantemente pelos não disponíveis, tinham em sua maioria as seguintes características: a) eram chefiadas por mulheres e sem o cônjuge (38\%); b) estavam em formação (69\% são jovens ou muito jovens); c) tinham apenas mulheres entre os disponíveis (58\%); d) o chefe tinha relações informais de trabalho (49\% trabalham por conta própria e $15 \%$ como parceiro/meeiro); e) o chefe estava vinculado ao setor primário. Zylberstajn (1985) verificou que $20 \%$ das famílias pobres formavam sua renda exclusivamente com contribuições de seus jovens e menores (não disponíveis) e $9 \%$ formavam sua renda com contribuições de membros adultos e de menores e jovens.

O desemprego é um grave problema social que vêm afetando economias desenvolvidas e em desenvolvimento. Apesar da gravidade da questão o assunto tem sido pouco explorado no Brasil. A Tabela 1 compara a trajetória das taxas de desemprego no período de 1986 a 1993 e 1997, para países selecionados de cinco continentes: Canadá e Estados Unidos (América do Norte), Coréia do Sul e Japão (Ásia), Austrália e Nova Zelândia (Oceania), Chile e Brasil (América Latina), Espanha, Alemanha, França, Reino Unido e Suécia (Europa).

\footnotetext{
${ }^{6}$ São indivíduos que não deveriam estar trabalhando, como menores de 14 anos, jovens sem o curso primário completo, estudantes e maiores de 70 anos.
} 
Tabela 1. Taxas de desemprego para diversos países para o período de 1986 a 1993 e 1997.

\begin{tabular}{lcccccccccc}
\hline & 1986 & 1987 & 1988 & 1989 & 1990 & 1991 & 1992 & 1993 & $1997^{*}$ & Média \\
\hline Canadá & 9,5 & 8,8 & 7,8 & 7,5 & 8,1 & 10,3 & 11,3 & 11,2 & 9,2 & 9,3 \\
EUA & 6,9 & 6,1 & 5,4 & 5,2 & 5,4 & 6,6 & 7,3 & 6,7 & 4,9 & 6,2 \\
Coréia & 3,8 & 3,1 & 2,5 & 2,6 & 2,4 & 2,3 & 2,4 & 2,8 & 2,6 & 2,7 \\
Japão & 2,8 & 2,8 & 2,5 & 2,3 & 2,1 & 2,1 & 2,2 & 2,5 & 3,4 & 2,4 \\
Austrália & 8,1 & 8,1 & 7,2 & 6,2 & 6,9 & 9,6 & 10,8 & 10,9 & 8,4 & 8,5 \\
N. Zelândia & 4,0 & 4,0 & 5,6 & 7,1 & 7,8 & 10,3 & 10,3 & 9,5 & 6,7 & 7,3 \\
Chile & 8,8 & 7,9 & 6,3 & 5,3 & 5,6 & 5,3 & 4,4 & 4,5 & 5,3 & 6,0 \\
Espanha & 21,2 & 20,5 & 19,5 & 17,3 & 16,3 & 16,4 & 18,4 & 22,7 & 20,6 & 19,0 \\
França & 10,4 & 10,5 & 10,0 & 9,4 & 8,9 & 9,4 & 10,2 & 11,6 & 12,3 & 10,1 \\
Alemanha & 8,8 & 9,0 & 8,7 & 8,0 & 7,0 & 10,3 & 14,8 & 8,2 & 9,8 & 9,4 \\
Reino Unido & 11,2 & 10,7 & 8,8 & 7,2 & 6,8 & 8,3 & 9,6 & 10,2 & 7,1 & 9,1 \\
Suécia & 2,2 & 1,9 & 1,6 & 1,4 & 1,5 & 2,7 & 4,8 & 8,2 & 7,9 & 3,0 \\
Média & 8,1 & 7,8 & 7,2 & 6,6 & 6,7 & 7,8 & 8,9 & 9,1 & 8,18 & 7,8 \\
Brasil & 3,6 & 3,7 & 3,8 & 3,3 & 4,3 & 4,8 & 5,9 & 5,4 & 5,7 & 4,4 \\
\hline
\end{tabular}

Fonte: Corseul, Reis e Urani (1996).

"Estes valores foram retirados de OIT (2000), Tabela 2, exceto para o Brasil, pois o último valor para o país era de 1996, constando na fonte citada. O dado do Brasil foi coletado junto à Revista Conjuntura Econômica (FGV) - março de 2000.

Observa-se que apenas três destes 12 países registraram, no período, taxas inferiores às brasileiras, durante o período como um todo (Japão, Coréia e Suécia). Em 1993 a taxa de desemprego brasileira foi ultrapassada pela sueca e tomou-se superior à chilena. Em 1997 a taxa de desemprego brasileira tomou-se superior à americana. No período de 86 a 93 a taxa média brasileira foi cerca de $40 \%$ menor que a do conjunto destes países e quase 30\% inferior à dos Estados Unidos - um país em que, na literatura internacional, a taxa de desemprego é considerada muito baixa. Em 1997 a taxa média de desemprego brasileiro foi aproximadamente 30\% inferior à média dos países selecionados e $16 \%$ superior à americana.

A taxa de desemprego brasileira pode, portanto, ser considerada baixa para os padrões internacionais. Ao longo do período de desemprego como um todo, todos os países, exceto o Chile, registraram aumentos de sua taxa de desemprego. Ou seja, o aumento do desemprego verificado no Brasil na primeira metade dos anos 90 não foi um fenômeno isolado. 
"Os argumentos tradicionais para explicar as elevadas taxas de desemprego nos países europeus são diversos, por vezes excludentes uns aos outros, e bem conhecidos. Por um lado, o aumento experimentado em meados dos anos 70 é atribuído aos choques de oferta. Por outro, as explicações para sua permanência em patamares tão elevados a partir de então vão da implementação de políticas de cunho restritivo a uma gama de argumentos institucionais, como o poder excessivo dos sindicatos, o desincentivo à oferta de trabalho proporcionado por um sistema de seguro desemprego demasiadamente generoso e aos elevados encargos trabalhistas sobretudo no que concerne à movimentação de mão-de-obra. $\mathrm{O}$ debate internacional se revitalizou com a nova mudança de patamar experimentada mundo afora na década de 90 . Desta vez, o aumento do desemprego vem sendo associado à reestruturação produtiva provocada pela crescente globalização e ao avanço tecnológico" (Corseuil et al., 1996, p. 465).

Apesar da taxa de desemprego brasileira ser relativamente baixa ela apresenta-se elevada para alguns segmentos da população, sendo mais alta para as mulheres e para os jovens. Particularmente para os jovens, as taxas de desemprego mundo afora têm se mostrado extremamente elevadas. Segundo a OIT (2000), a taxa de desemprego entre os jovens é aproximadamente o dobro da taxa de desemprego entre os adultos com idade entre 25 a 64 anos, como pode ser observado na Figura 3.

A taxa de desemprego entre os jovens é particularmente alta na Argentina, França, Itália e Espanha. Examinando a taxa de desemprego para homens e mulheres adultos, observa-se que esta é quase sempre maior para as mulheres, exceto para o Reino Unido, Austrália e Nova Zelândia. 


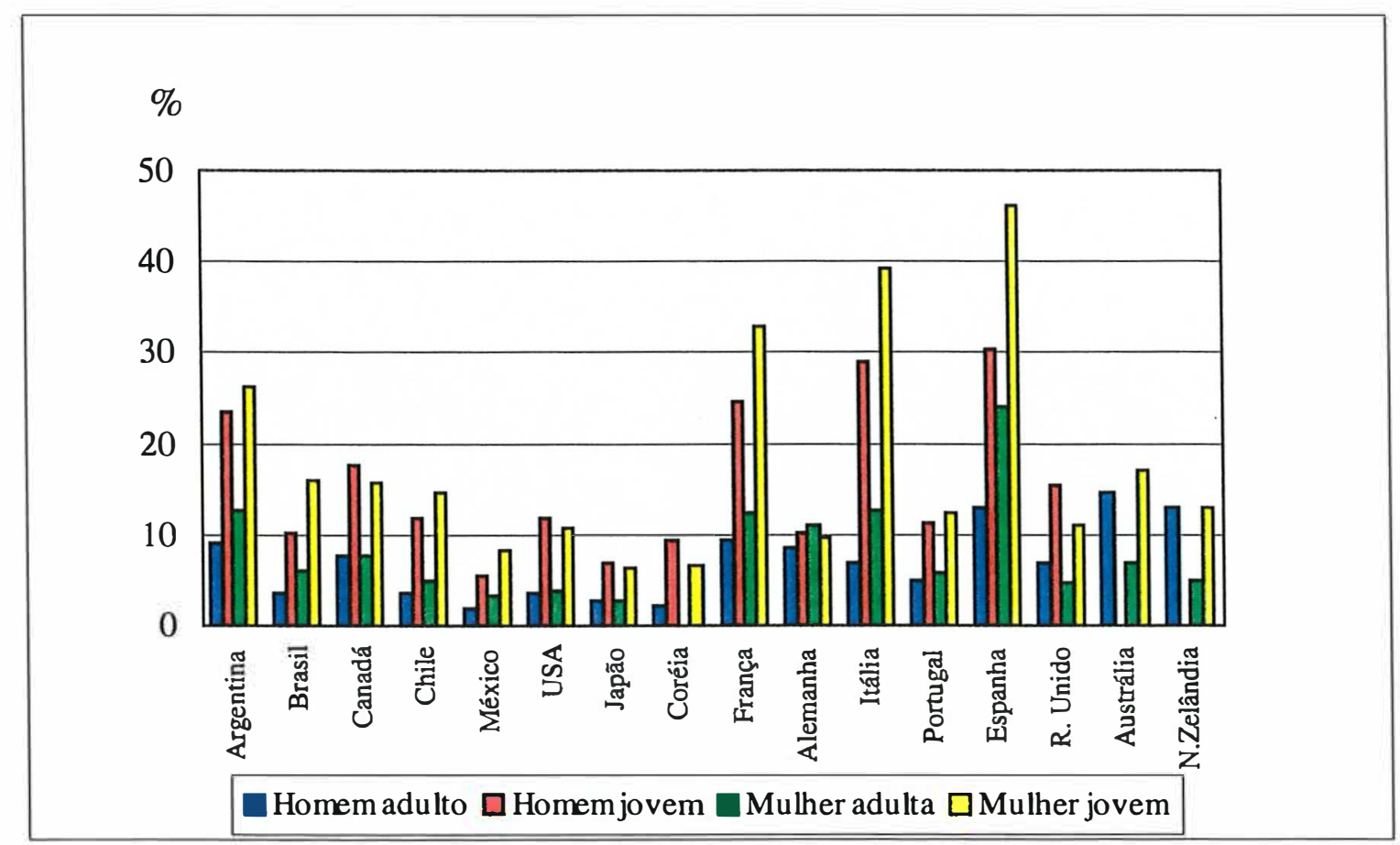

Figura 3 - Taxas de desemprego para diversos países estratificado por adultos (25 ou mais anos de idade) e jovens (15 a 24 anos) e por gênero - Brasil, Argentina e Portugal em 1996 e demais países em1998 (Fonte: OIT, 2000, Tabela 2) ${ }^{7}$.

Entre os jovens, a taxa de desemprego é menor para os homens em todas as economias em desenvolvimento. Na maioria dos países desenvolvidos observa-se que as taxas de desemprego são mais elevadas para os homens jovens em relação às mulheres jovens, exceto para França, Itália e Portugal.

Segundo Pochmann (1998), a inserção ocupacional do jovem brasileiro passou a ser rápida e profundamente alterada a partir da década de 80 com o fim do ciclo virtuoso do crescimento econômico e o ingresso em um período de estagnação da renda por habitante, alto desemprego e baixa mobilidade social. Ademais, teve início na década de 80 e estabeleceu-se com mais clareza nos anos 90 o desassalariamento (perda de participação relativa dos empregos assalariados no total da ocupação) e a geração de postos precários.

${ }^{7} \mathrm{Na}$ fonte de dados não constavam dados para as mulheres adultas da Coréia e para homens jovens da Austrália e N. Zelândia. 
Pochmann (1998) verificou que a taxa de desemprego aberto para jovens com idade entre 15 e 19 anos, em 1997, foi de 13\%, quase três vezes superior à observada em 1980 (4,8\%). Pochmann mostra ainda que todas as regiões geográficas brasileiras registraram expansão significativa do desemprego entre os jovens. Entre 1986 e 1996, o desemprego juvenil cresceu mais na região Centro-Oeste (292\%), seguida da região Sul (248\%), da região Sudeste (198\%), da região Norte (192\%) e da região Nordeste (171\%). Em decorrência disso, segundo o autor, houve alterações na composição regional do desemprego juvenil. Em 1996, a região Sudeste foi responsável por $48,7 \%$ do total do desemprego juvenil, seguida da região Nordeste $(24,7 \%)$, da região Sul $(12,9 \%)$, da região Centro-Oeste $(8,5 \%)$ e da região Norte $(5,2 \%)$, ao passo que em 1986, a região Sudeste era responsável por 52,8\% do desemprego juvenil, seguida da região Nordeste $(25,1 \%)$, da região Sul $(12,7 \%)$, da região Centro-Oeste $(6,3 \%)$ e da região Norte $(3,1 \%)$.

Pochmann (1998) trata ainda sobre a questão do desassalariamento, o qual, segundo o autor, é um fenômeno que atinge todos os trabalhadores brasileiros, especialmente os jovens. É um processo que decorre tanto da destruição dos empregos assalariados em maior quantidade do que são criados quanto da expansão dos postos de trabalho não assalariados dos jovens nos anos 90. Conforme o autor, no período de 1989 a 1996, o emprego assalariado do jovem foi reduzido em $23,8 \%$. No período de 1986 a 1996 a evolução dos empregos assalariados apresentou maior redução em certas regiões, especialmente na região Nordeste $(-25,9 \%)$, seguida da região Sudeste $(-25,3 \%)$ e da região Sul (-23,9\%), a região Centro-Oeste apresenta uma redução de $21,8 \%$. Somente a região Norte apresentou evolução positiva do emprego assalariado $(14,1 \%)$.

Camarano (2000) verificou que a taxa de desemprego do grupo de jovens, com idade entre 18 e 24 anos, foi de $15 \%$, enquanto a mesma foi de 5\% para a população adulta com idade entre 40-49 anos. Segundo a autora, a taxa de desemprego para os jovens pode estar subestimada, devido ao que os economistas chamam de "desemprego por desalento", isto é, as pessoas desistem de procurar emprego pela consciência de sua falta. 
De acordo com Amadeo (1998), entre 1992 e 1996, o número de postos de trabalho no Brasil cresceu pouco mais de $8 \%$. Conforme verificado pelo autor a geração de empregos no Brasil tem privilegiado os trabalhadores com maior nível de escolaridade. O emprego dos trabalhadores com menos de cinco anos de escolaridade caiu $8 \%$ entre 1992 e 96 . Já o emprego de trabalhadores com cinco a oito anos de estudo cresceu quase 20\%, enquanto o emprego do grupo de 9 a 11 anos cresceu $28 \%$. Portanto, vê-se que por trás do crescimento de $8 \%$ do emprego médio total, esconde-se um crescimento muito significativo do emprego de trabalhadores com níveis mediano e alto de instrução. Tal tendência pode ter dois significados: o primeiro seria que os jovens podem ser beneficiados nos próximos anos devido a sua maior escolarização média comparativamente ao resto da população. A educação do Brasil apresentou melhoria significativa nas últimas décadas, com redução na taxa de analfabetismo, aumento no número de matrículas em todos os níveis de ensino e crescimento da escolaridade média da população. Por outro lado, o aumento de escolarização não está afetando igualmente todas as classes sociais. Segundo PNUD (1996), 80\% dos adolescentes de famílias com renda de mais de dois salários mínimos per capita freqüentou escola, enquanto apenas $40 \%$ daqueles com famílias pobres conseguem permanecer estudando. Isto pode estar indicando que o desemprego pode estar afetando mais estes últimos, apesar da maior necessidade de os jovens pobres trabalhar.

Blanchflower e Freeman (2000) mostraram que o sucesso na transição da escola para o trabalho nos países industrializados está intimamente relacionado com o nível de escolaridade dos jovens. A taxa de desemprego entre os jovens é, geralmente, superior para aqueles com menor nível de escolaridade. $\mathrm{Na}$ maioria dos países analisados, um terço dos jovens com menos escolaridade estava desempregado um ano após ter deixado os estudos.

Pouco se sabe a respeito das causas do desemprego entre os jovens. De acordo com a OIT (2000), há pouca evidência de que o tamanho da população jovem seja uma das principais causas, pois em muitos países onde tem as maiores taxas de desemprego entre os jovens o crescimento relativo da população jovem está em queda. 
O nível dos salários entre os jovens também não explica a persistência do desemprego entre os jovens, que têm diminuído, bem como não há fortes evidências de que a existência de salário mínimo fixado por lei explique o aumento do desemprego jovem nas duas últimas décadas. As principais explicações para o aumento do desemprego jovem, segundo a organização, seriam as mudanças que vêm ocorrendo na demanda agregada, o aumento da demanda por trabalhadores mais qualificados e o aumento da participação da mulher no mercado de trabalho, já que esta compete com o jovem pelas vagas existentes.

A situação de alto desemprego entre os jovens compromete seu futuro desempenho sócio-econômico, tornando necessária a compreensão do fenômeno da exclusão juvenil do mercado de trabalho, com vistas a viabilizar a integração social e econômica dos jovens. "A exclusão dos jovens no Brasil decorre de uma série de razões, presentes também no contexto latino americano, de alto subemprego e desemprego entre os jovens, acentuado nos grupos de mais baixa escolaridade, o que acaba repercutindo como fator determinante para toda a vida, pois uma indevida preparação profissional nesta fase pode ocasionar em uma maturidade incompleta e em falta de definição de projetos de futuro adequados para os jovens.

O que era, em muitos países, considerado um fenômeno desprezível de marginalidade juvenil minoritária e isolado, vem se transformando cada vez mais num processo de "exclusão juvenil" em plena expansão. Esta mais drástica forma de exclusão social decorre das causas estruturais e conjunturais do desemprego, junto com a inadequação dos sistemas de educação diante das exigências do mercado de trabalho. Paradoxalmente, o desemprego juvenil convive com o fato de que muitos postos de trabalho existentes em diversos setores deixam de ser preenchidos porque a mão-de-obra disponível não possui requisitos educacionais mínimos para ocupá-los" (OIT, 1999).

Examinado-se a literatura internacional sobre os jovens no mercado de trabalho, observa-se que as pesquisas concentram-se na compreensão do desemprego do jovem, no efeito do tamanho da população jovem sobre seus rendimentos e desemprego, 
na dificuldade de conseguir o primeiro emprego e na duração do período de desemprego, sendo o tema amplamente debatido nos países industrializados. Já nas sociedades menos avançadas a preocupação central é com o excessivo e, freqüentemente, inadequado trabalho das crianças que participam efetivamente do mercado, em muitos países, a partir de 5-7 anos de idade.

De acordo com Blanchflower e Freeman (2000), os baixos salários dos trabalhadores jovens refletem sua menor produtividade em relação aos trabalhadores adultos e o sacrifício de algum rendimento potencial para investir em treinamento. As altas taxas de desemprego entre os jovens é em parte devido ao período transitório em que se encontram, mudando do mundo da escola para o mundo do trabalho e mudando da casa dos pais para viverem sozinhos.

Ainda de acordo com os autores, nos anos 70, a situação do jovem no mercado de trabalho piorou notavelmente, aparentemente devido a um enorme aumento na oferta de rabalhadores jovens, resultado este do "baby boom". A maioria dos analistas do mercado de trabalho esperava melhora da situação do jovem em relação ao trabalho, assim que o tamanho relativo da população jovem declinasse em tamanho. Mas a diferença nos rendimentos dos jovens em relação aos adultos aumentou substancialmente na década de 80 e 90 . Em praticamente todos os países industrializados a população jovem é muito menor e melhor educada que no passado, mas o problema do jovem no mercado de trabalho permanece, e em muitos casos em situação pior que antes.

Análise empírica realizada por Bloom et al. (1987), para diversos países industrializados nos anos 70 e início de 80, indicou que o aumento do tamanho da população jovem tende a ter efeito sobre o nível de rendimentos e de emprego para essa mesma população. Em alguns países foi observado que o aumento da população jovem produziu efeito negativo sobre os rendimentos e reduziu o nível relativo de emprego da população jovem em outros países. Ademais, os autores apresentaram uma revisão de diversos estudos empíricos que mostraram os efeitos do tamanho da população jovem 
sobre os rendimentos e desemprego, sendo que, apesar das diferenças existentes entre os estudos, as conclusões convergem no que diz respeito à queda dos rendimentos e/ou aumento do desemprego relativo quando da entrada de uma grande população jovem relativamente a uma menor população jovem.

Freeman (1979) analisou dados que mostraram que o tamanho da população jovem é negativamente correlacionada com os rendimentos relativos de trabalhadores homens jovens (especialmente para jovens com curso superior) e não correlacionados com rendimentos relativos das mulheres jovens. Equações estruturais de demanda por trabalho foram utilizadas para estimar o grau de substitubilidade entre trabalhadores jovens e adultos. A análise mostrou que o tamanho da população jovem tem efeito negativo e significativo nos rendimentos dos jovens trabalhadores, em grande parte devido ao fato de os jovens serem substitutos imperfeitos para trabalhadores adultos.

Card e Lemieux (1997) estudaram como os jovens americanos e canadenses responderam às mudanças no mercado de trabalho, em particular ao aumento no desemprego da população jovem, no período de 1970 a 1994. A partir do final dos anos 70 , o aumento da fração jovem produziu um choque de oferta de jovens no mercado de trabalho americano e canadense, resultando em pressão negativa dos salários dos mesmos. Ademais, houve queda na demanda por trabalhadores com baixo capital humano, intensificando ainda mais a queda do salário dos jovens, além de elevar suas taxas de desemprego. Mudanças na estrutura familiar também impactaram negativamente os jovens, tais como o aumento de nascimento de crianças fora do casamento e aumento da taxa de divórcio.

Os autores observaram que em regiões onde existia alta demanda pelo trabalho dos jovens e altos salários, a probabilidade dos homens trabalharem, de deixar a casa dos pais para morarem sozinhos e de não estudar, era significativamente maior do que em regiões onde a demanda e salários pagos pelo trabalho dos jovens estavam deprimidos. Para as mulheres, observaram as mesmas tendências, não verificando apenas correlação entre as condições do mercado de trabalho com as taxas de matrículas 
escolares. Observa-se então, que neste caso, a principal resposta dos jovens à crise no mercado de trabalho foi de investir mais em sua educação.

Blanchflower e Freeman (2000) observaram mudanças de comportamento dos jovens residentes nos países industrializados, as quais são vistas como respostas dos jovens às piores condições encontradas no mercado de trabalho. A mais importante e positiva mudança observada foi o adiamento da entrada no mercado de trabalho pelos jovens e a permanência na escola, em praticamente todas as economias industrializadas as taxas de matrículas aumentaram entre as décadas de 80 e 90 . A segunda mudança observada no comportamento dos jovens tem sido a permanência destes por um período maior na casa dos pais e a postergação da formação das próprias fanúlias. Segundo os autores, entre 1971 e 1994, a proporção de homens americanos com idade entre 16 e 24 anos que eram chefes ou cônjuges em suas próprias famílias caiu de $22 \%$ para $11 \%$, no Canadá a proporção caiu de 16 para $8 \%$. Entre as mulheres a tendência observada foi similar: uma queda de 36 para $24 \%$ nos Estados Unidos e de 30 a 17\% no Canadá. A terceira resposta observada à piora nas oportunidades econômicas dos jovens é extremamente negativa e prejudicial para os jovens e sociedade, trata-se do aumento do envolvimento dos jovens em crimes.

Nilsen e Bratberg (1998) ${ }^{8}$, a partir de dados de indivíduos da Noruega, analisaram a transição de jovens da escola para o trabalho e a duração do primeiro trabalho. Encontrou evidências de que indivíduos com níveis mais altos de escolaridade conseguem seu primeiro trabalho mais cedo, e também ficam um período maior em seu primeiro trabalho. Ademais, observou que o período de procura por trabalho para as mulheres era menor, bem como seus salários, o que pode indicar que possuem salário reserva menor que os homens, sendo que as mulheres sempre permanecem no primeiro trabalho um período mais longo que os homens.

${ }^{8}$ NIISEN, O. A; BRATBERG, E. Transitions from school to work: search time and job duration, Noruega. Dec. 1998 (artigo enviado por meio eletrônico). 
Barret et al. (1999) usaram dados da Irlanda no período de 1987 a 1994 para estimar equações de salário para trabalhadores jovens na Irlanda, tendo encontrado substanciais retomos à educação universitária. Observaram ainda que os retornos para níveis medianos de escolaridade caíram no decorrer do tempo. Os autores concluíram que os retornos refletem a maior demanda por trabalhadores mais qualificados no mercado de trabalho internacional, pelo fato da Irlanda possuir uma economia aberta.

Korenman e Neumark (1997), estudando o mercado de trabalho dos jovens nas economias desenvolvidas nas décadas de 70, 80 e início dos anos 90, verificaram que nos países europeus os jovens estavam enfrentando uma crise de desemprego. No período de 1970 a 1994, a média da taxa de desemprego para os jovens com idade entre 15 e 24 anos, em 11 países europeus estudados, aumentou de 4,2\% para 20,6\% e a média da taxa de emprego caiu de $59 \%$ para $41 \%$. Nos Estados Unidos, no mesmo período, a taxa de desemprego dos jovens aumentou de 11,0 para $12,5 \%$.

Os autores citados acima estimaram uma série de regressões objetivando isolar os efeitos de mudanças exógenas na oferta potencial de trabalho pelos jovens sobre as taxas de emprego e desemprego. Para tanto utilizaram dados de painéis para 15 países em um período de 20 anos. Os resultados encontrados indicaram que quanto maior a população jovem, maior é a taxa de desemprego associada. Encontraram ainda valores de elasticidade da taxa de desemprego em relação ao tamanho da população jovem na faixa de 0,5 a 0,6 . Por outro lado, as estimativas indicaram que o tamanho da população jovem tem pouco efeito nas taxas de emprego.

Lynch $(1985,1989)$ procurou determinar os fatores que influenciam a duração do desemprego entre os jovens, sendo o estudo de 1985 , realizado a partir de dados de indivíduos ingleses e o estudo de 1989 de indivíduos americanos. Nos dois estudos encontrou fortes evidências de que a probabilidade de um indivíduo encontrar emprego é significativamente menor para os não brancos, mesmo após controlar a variabilidade de outras características. Outro fator determinante na probabilidade do indivíduo conseguir emprego é a duração do desemprego no período corrente e duração 
do desemprego em períodos anteriores, que afetam negativamente a probabilidade do indivíduo conseguir trabalho.

Os temas debatidos no contexto internacional são extremamente interessantes e relevantes. Entretanto, os dados disponíveis no Brasil inviabilizam a utilização de quaisquer das metodologias empregadas nos trabalhos, visto que todos utilizaram dados em painel. As bases de dados utilizadas nos trabalhos citados são extremamente ricas, pois acompanham a vida sócio-econômica dos indivíduos, permitindo captar as mudanças que acontecem no decorrer do tempo.

Além dos problemas econômicos gerados pelo desemprego entre os jovens, talvez, o mais grave seja que "o desemprego e a baixa empregabilidade dos jovens têm contribuído para o aumento da violência, da prostituição, e do consumo de álcool e drogas, assim como sua vulnerabilidade social em todo o mundo" (OIT, 1999, p. 2). Vários estudos correlacionam a situação de desemprego com criminalidade juvenil. Em estudo realizado pela OIT (2000), aspectos extremamente negativos foram observados em situação de alto desemprego entre os jovens, tais como consumo de drogas, aumento na participação em crimes e aumento de suicídio. Freeman (1996) apresenta evidências que o mercado de trabalho em crise para homens menos especializados nas décadas de 80 e início dos anos 90 tem contribuído para aumentar o crime por estes homens. Em contrapartida, Freeman (1999) estimou os efeitos do impacto da expansão da economia americana, no período de 1992 a 1998, sobre o mercado de trabalho para os homens com menos escolaridade. Entre outros resultados, observou maior queda na taxa de criminalidade nos estados onde a taxa de desemprego entre os jovens caiu mais. Ademais, vários estudos na área médica procuram correlacionar a saúde dos indivíduos com o status ocupacional, tendo vários deles mostrado associação entre desemprego e doenças físicas e psíquicas (como depressão e perda de confiança) entre os jovens. Alguns trabalhos demonstram, ainda, que desemprego e suicídio entre os jovens estão altamente correlacionados (ver, entre outros, Goldsmith, et al., 1996, Morrel, et al., 1998; Morrel, et al.,1999; Wadsworth, et al., 1999; Carmichael et al., 2000). Portanto, existem fortes evidências de que a falta de perspectiva enfrentada pelos jovens em um 
ambiente de altas taxas de desemprego gera graves problemas sociais, os quais, são mais difíceis de serem equacionados que a própria causa. 


\section{DADOS}

Os estudos sobre o mercado de trabalho no Brasil em geral apoiam-se nos levantamentos realizados pelo Instituto Brasileiro de Geografia e Estatística (IBGE) por meio dos Censos Demográficos, Pesquisa Mensal do Emprego (PME) e nas Pesquisas Nacionais por Amostra de Domicílios (PNADs). Estas últimas são fontes ricas de dados sobre os padrões social e econômico dos indivíduos e permitem o estudo do desenvolvimento sócio-econômico do país.

$\mathrm{Na}$ realização deste estudo serão utilizados dados desagregados da PNAD de 1998. Os dados a serem utilizados são muito ricos, por tratarem-se de informações individuais, denominados microdados. Os dados que compõem esta pesquisa são obtidos de uma amostra de milhares de indivíduos, onde se têm detalhes da vida sócioeconômica de cada um, tais como rendimento do trabalho, região onde vive, raça, nível de escolaridade, idade, número e idade das crianças por família, posição do indivíduo na família, atividade que o indivíduo exerce, número de horas trabalhadas, etc. Os dados

foram coletados em setembro de 1998, tendo sido entrevistados 344.975 indivíduos em 112.434 unidades domiciliares. Utilizando-se o fator de expansão da amostra encontrase o total da população brasileira que, em 1998, era de 158.232.252.

Foram eliminados da amostra os indivíduos cuja resposta para as seguintes questões era ignorada: idade do morador, número de anos de estudo, número de horas trabalhadas por semana, idade que começou a trabalhar, cor ou raça e as variáveis de renda. Após estas exclusões a amostra reduziu-se a 333.527 indivíduos. Estes indivíduos, tomando o peso de cada um na amostra, representam 153.171.032 pessoas. 
Na parte referente à análise econométrica o universo de análise será restrito a homens e mulheres jovens, na faixa etária entre 15 e 24 anos. A população adulta, com idade entre 25 e 64 anos será utilizada apenas em análises preliminares, como forma de se obter uma comparação relativa dos dois grupos. A amostra de jovens usada neste estudo é composta por 32.358 homens e 32.842 mulheres, onde $18,3 \%$ dos homens e $16,0 \%$ das mulheres têm domicílio na zona rural e os demais na zona urbana. A amostra de adultos é composta por 70.111 homens e 77.135 mulheres, sendo 17,9\% dos homens e $15,4 \%$ das mulheres população rural. 


\section{ANÁLISE DESCRITIVA DOS DADOS}

Segundo a amostra utilizada da Pesquisa Nacional por Amostra de Domicílios de 1998, de uma população de mais de 153 milhões, cerca de 30 milhões $(19,4 \%)$ era constituída por indivíduos de 15 a 24 anos de idade. Destes 30 milhões de jovens, cerca de 19 milhões $(62,8 \%)$ eram PEA (População Economicamente Ativa).

\subsection{Condição de atividade}

A população pode ser dividida quanto à sua condição de atividade em duas: população economicamente ativa e população não economicamente ativa. A PNAD considera como PEA o segmento da população que está empregado (ocupado) ou que esteve procurando trabalho (desocupados) no período de referência - será adotado como período de referência a semana em que foi realizada a pesquisa: 20 a 26 de setembro de 1998. A população não economicamente ativa é formada por todos os demais indivíduos.

A Tabela 2 mostra a taxa de atividade ${ }^{9}$ para jovens e adultos, estratificada por gênero, situação de domicílio (urbano e rural), regiões (Norte, Nordeste, CentroOeste, Sudeste e Sul), escolaridade (sem instrução e menos de 1 ano, 1 a 3 anos de estudo, 4 a 7 anos, 8 a 10 anos, 11 a 14 anos e 15 ou mais anos), cor (brancos, pardos e pretos) e posição no domicílio (chefe, cônjuge, filho e outro).

\footnotetext{
${ }^{9}$ A taxa de atividade é obtida através da razão entre os ativos e o total de indivíduos da amostra.
} 
Tabela 2. Taxa de atividade dos jovens e adultos, estratificada por gênero e por categorias (situação de domicílio, regiões, escolaridade, cor e posição no domicílio).

\begin{tabular}{lcccc}
\hline & \multicolumn{2}{c}{ Jovens de 15 a 24 anos } & \multicolumn{2}{c}{ Adultos de 25 a 64 anos } \\
\cline { 2 - 5 } & Homens & Mulheres & Homens & Mulheres \\
\hline Urbano & 71,8 & 50,3 & 89,3 & 57,5 \\
Rural & 87,0 & 50,9 & 95,1 & 66,4 \\
& & & & \\
Norte & 69,4 & 42,9 & 91,8 & 61,3 \\
Nordeste & 75,2 & 45,3 & 91,3 & 60,9 \\
Centro-Oeste & 77,9 & 52,7 & 93,4 & 61,7 \\
Sul & 80,2 & 56,8 & 92,3 & 64,3 \\
Sudeste & 73,3 & 52,6 & 88,8 & 55,5 \\
& & & & \\
Sem instrução e & & & & \\
menos de 1 ano & 78,7 & 37,0 & 86,8 & 47,8 \\
1 a 3 anos & 80,5 & 45,9 & 89,4 & 52,8 \\
4 a 7 anos & 73,8 & 44,2 & 90,3 & 55,5 \\
8 a 10 anos & 68,9 & 47,6 & 92,1 & 58,2 \\
11 a 14 anos & 81,7 & 70,9 & 93,0 & 71,2 \\
15 anos ou mais & 80,6 & 76,9 & 93,0 & 83,0 \\
& & & & \\
Brancos & 73,6 & 51,4 & 90,2 & 58,2 \\
Pardos & 76,3 & 48,8 & 91,3 & 59,9 \\
Pretos & 76,6 & 53,7 & 88,2 & 61,6 \\
& & & & \\
Chefe & 96,8 & 63,3 & 91,9 & 67,5 \\
Filho & 95,0 & 44,2 & 88,3 & 54,5 \\
Cônjuge & 70,6 & 50,2 & 84,5 & 73,1 \\
Outro & 75,0 & 59,6 & 79,1 & 60,7 \\
\hline
\end{tabular}

Fonte: PNAD/1BGE, 1998 (microdados).

Os resultados da Tabela 2 mostram que a taxa de atividade dos homens é sempre maior que das mulheres e dos adultos maior que dos jovens. Uma taxa de atividade maior entre os homens em relação às mulheres é um fato universalmente observado. Este fato é, segundo Barros e Mendonça (1991), em parte, explicado por um mercado de trabalho menos atraente para as mulheres, devido aos baixos salários oferecidos a elas comparativamente ao salário oferecido aos homens. Além disso, fatores culturais também comprometem negativamente a taxa de atividade das mulheres, tanto 
por um tradicional maior envolvimento delas nos afazeres domésticos e cuidado com as crianças quanto por restrições a certas ocupações e locais ou horários de trabalho.

A maior taxa de atividade dos adultos em relação aos jovens é um fenômeno esperado, uma vez que grande parte dos jovens ainda tem parte de seu tempo comprometido com os estudos, além de suporte financeiro por parte da família. Ademais, as exigências do mercado de trabalho (experiência, escolaridade, disponibilidade) tornam o acesso de muitos jovens ao mercado bastante restrito.

A taxa de atividade é sempre maior na zona rural comparativamente à zona urbana. Tal resultado pode estar relacionado com os recursos econômicos das famílias, ou seja, é amplamente divulgado o fato de que a renda per capita rural é significativamente mais baixa que da zona urbana, o que leva a família disponibilizar o maior número possível de membros da unidade familiar para o trabalho. Outro fator que pode explicar este resultado, principalmente para os jovens, são as alternativas ao trabalho existentes, digo, na zona urbana o jovem possui maior oportunidade de estudo e lazer em relação ao jovem residente na zona rural, bem como maior incentivo para a realização de tais atividades. Ademais, na zona rural existe uma proporção substancial de indivíduos inseridos em trabalhos não remunerados e na produção para próprio consumo ou construção para o próprio uso, atividades estas que absorvem a maior parte dos jovens residentes neste local, como poderá ser visto na Tabela 5, o que leva a uma maior possibilidade do indivíduo encontrar ocupação na zona rural que na urbana.

Para o conjunto das regiões, as taxas de atividade dos homens é cerca de $50 \%$ maior que das mulheres. A região Sul, seguida da região Centro-Oeste, apresentam as maiores taxas de atividade para os jovens, enquanto a maior taxa de atividade para os adultos é encontrada na região Centro-Oeste para homens e região Sul para as mulheres. A menor taxa de atividade para os jovens é encontrada na região Norte, enquanto para os adultos encontra-se na região Sudeste. Tal resultado pode estar indicando que as condições vigentes no mercado de trabalho podem ser importante fator na determinação 
da participação dos jovens na força de trabalho, ou seja, a atividade dos jovens está intimamente relacionada à atratividade do mercado de trabalho. Onde os salários ofertados são maiores e, as chances de se obter emprego com carteira de trabalho assinada são mais elevadas, as taxas de participação do jovem no mercado de trabalho são mais elevadas. Conforme poderá ser visto mais adiante, os salários pagos aos trabalhadores são significativamente melhores nas regiões Sudeste, Sul e Centro-Oeste. Silva (1997) constatou que nestas mesmas regiões são maiores as chances de se obter trabalho com carteira assinada.

Barros e Mendonça (1990) chegaram a resultados semelhantes, tendo como universo de análise menores de 10 a 17 anos de idade residentes em regiões metropolitanas. Encontraram taxas de participação no mercado de trabalho significativamente mais elevadas para as regiões metropolitanas de São Paulo e Porto Alegre quando comparadas à região metropolitana de Fortaleza. Constataram assim, que as diferenças regionais parecem indicar que as decisões dos menores trabalharem são decisivamente influenciadas pela atratividade do mercado de trabalho em que se inserem.

A Tabela 2 mostra que a escolaridade afeta positivamente a taxa de atividade dos adultos e das mulheres jovens. Tal fato deve estar refletindo o efeito do salário na atratividade do mercado de trabalho, ou seja, o aumento no número de anos de estudo eleva o nível de capital humano, o que deve afetar positivamente o nível salarial, este, tudo mais constante, deve aumentar a atratividade do mercado de trabalho. Tal tendência não se verifica para os homens jovens, para os quais, a taxa de atividade apresenta forma semelhante a de "U". A não existência de tendência crescente do nível de atividade dos homens jovens com aumento nos anos de estudo deve se dar devido ao momento no ciclo de vida desta população, para os quais ainda existem alternativas tão ou mais atrativas que o trabalho, como o investimento na sua formação profissional com boas expectativas de rendimentos futuros. 
Observa-se que existe diferença nas taxas de atividade entre indivíduos de cor diferente, o que pode refletir diferenças étnicas e valores culturais entre os indivíduos. A taxa de atividade é maior para os pretos no caso de jovens e mulheres adultas e para os pardos no caso de homens adultos. Tal resultado pode se dar devido ao fato de os indivíduos não brancos entrarem mais cedo no mercado de trabalho, pois estudam menos que os brancos. Os negros também aceitam salários mais baixos, aumentando a sua probabilidade de encontrar trabalho. Por último, tem-se que numa família de cor branca a probabilidade do chefe de família poder sustentar toda a família com seu salário é maior que do chefe negro, de forma que, geralmente, a família da raça negra tem maior número de membros economicamente ativos por busca de sobrevivência.

De acordo com Barros e Mendonça (1990), a taxa de participação entre as pessoas de 10 a 17 anos de cor preta ou parda tende a ser maior que entre aquelas de cor branca ou amarela, o que segundo os autores pode refletir o fato de que estas vivem em famílias mais pobres, as quais necessitam recorrer ao trabalho de seus membros menores de 18 anos para complementar o orçamento.

Em relação à posição do indivíduo no domicílio tem-se que os indivíduos chefes de família possuem as maiores taxas de atividade, seguidos dos filhos homens (Tabela 2). Tal resultado é esperado, visto que, geralmente, são os indivíduos classificados como chefes os responsáveis pela maior parte do sustento da família, os demais membros apenas complementam a renda destes. Para mulheres adultas, observase que a maior taxa de atividade se dá para aquelas classificadas como cônjuges.

Na Tabela 3 encontra-se a porcentagem de todos os jovens que trabalham e a porcentagem de jovens que trabalham e recebem pagamento, segundo grupo de idade, sexo e situação de domicílio. Os dados mostram que a proporção de jovens trabalhando na zona rural é significativamente maior que a proporção de jovens que trabalham na zona urbana, sendo que na zona rural existe uma maior proporção de 
jovens que não auferem nenhum rendimento pelo seu trabalho comparativamente aos trabalhadores urbanos. A proporção de homens que trabalham é bem maior que a de mulheres, sendo a diferença mais significativa na zona rural. A Tabela mostra ainda que cerca de 50\% dos jovens nas áreas rurais não são pagos pelo seu trabalho e nas áreas urbanas $10 \%$ não recebe nenhum tipo de pagamento pelo trabalho exercido. Ademais, observa-se que a taxa de participação no mercado de trabalho cresce acentuadamente com a idade e a proporção de jovens trabalhadores não pagos é decrescente com a idade.

Tabela 3. Porcentagem de jovens trabalhando e porcentagem de jovens trabalhando que recebem pagamento, estratificada por grupo de idade, sexo e situação de domicílio.

\begin{tabular}{lcccccccc}
\hline & \multicolumn{3}{c}{ Jovens de 15 a 19 anos } & \multicolumn{3}{c}{ Jovens de 20 a 24 anos } \\
\cline { 2 - 9 } \begin{tabular}{l} 
Porcentagem domens \\
\multicolumn{2}{c}{ jovens }
\end{tabular} & Urbano & Rural & Urbano & Rural & Urbano & Rural & Urbano & Rural \\
\hline Trabalhando & 45,6 & 78,5 & 27,4 & 41,0 & 76,9 & 89,9 & 49,6 & 53,0 \\
Recebendo pgto. & 84,1 & 42,4 & 89,8 & 40,7 & 96,0 & 72,7 & 95,0 & 53,4 \\
\hline
\end{tabular}

Fonte: PNAD/IBGE, 1998 (microdados).

A Tabela 4 mostra o tipo de inserção dos jovens e adultos no mercado de trabalho. Como seria de se esperar, existe uma proporção maior de jovens no mercado de trabalho informal comparativamente aos adultos, indicando que a qualidade dos postos de trabalho entre os jovens é inferior à dos adultos, visto que é no mercado de trabalho informal que os salários pagos, na média, são os mais baixos e as condições de trabalho são piores, o que poderá ser constatado na Tabela 18.

Tabela 4. Porcentagem de jovens e adultos trabalhando, estratificada por sexo e mercado de trabalho.

\begin{tabular}{lcccc}
\hline & \multicolumn{2}{c}{ Jovens de 15 a 24 anos } & \multicolumn{2}{c}{ Adultos de 25 a 64 anos } \\
\cline { 2 - 5 } & Homens & Mulheres & Homens & Mulheres \\
\hline Mercado formal & 34,2 & 36,2 & 40,8 & 39,9 \\
Mercado informal & 64,9 & 63,2 & 52,6 & 57,3 \\
Empregadores & 0,9 & 0,6 & 6,6 & 2,8 \\
\hline
\end{tabular}

Fonte: PNAD/IBGE, 1998 (microdados).

A Tabela 5 apresenta as atividades mais desenvolvidas pelos jovens. Há uma grande porcentagem de trabalhadores jovens não remunerados ou produzindo para o 
próprio consumo ou trabalhando na construção para o próprio uso, sendo maior essa proporção no meio rural, podendo atingir $60 \%$ dos jovens trabalhadores. A proporção de trabalhadores jovens não remunerados ou produzindo para o próprio consumo ou trabalhando na construção para o próprio uso é substancialmente menor para a faixa etária de 20 a 24 anos em relação aos jovens de 15 a 19 anos, sendo a diferença entre as duas faixas etárias mais significativa entre os homens que entre as mulheres.

Tabela 5. Porcentagem de jovens trabalhando, estratificada por atividades, situação de domicílio, sexo e grupos de idade.

\begin{tabular}{lcccccccc}
\hline & \multicolumn{3}{c}{ Jovens de 15 a 19 anos } & \multicolumn{3}{c}{ Jovens de 20 a 24 anos } \\
\cline { 2 - 9 } & \multicolumn{3}{c}{ Homens } & \multicolumn{2}{c}{ Mulheres } & \multicolumn{2}{c}{ Homens } & \multicolumn{2}{c}{ Mulheres } \\
\cline { 2 - 9 } Atividades & Urbano & Rural & Urbano & Rural & Urbano & Rural & Urbano & Rural \\
\hline Empregado & 74,9 & 36,2 & 54,9 & 16,6 & 79,9 & 54,1 & 64,9 & 30,8 \\
Trabalhador doméstico & 0,8 & 0,5 & 30,0 & 19,2 & 0,7 & 1,1 & 20,7 & 13,9 \\
Conta-própria & 9,1 & 6,1 & 5,2 & 5,3 & 13,7 & 18,0 & 8,6 & 8,4 \\
Empregador & 0,2 & 0,1 & 0,2 & 0,0 & 1,8 & 0,4 & 1,0 & 0,4 \\
Trab. não-remunerado & 1,9 & 5,7 & 1,6 & 14,6 & 0,6 & 2,9 & 1,2 & 20,2 \\
Trab. na produção para & 13,1 & 51,4 & 8,1 & 44,4 & 3,3 & 23,5 & 3,6 & 26,4 \\
próprio consumo ou & & & & & & & & \\
construção próprio uso & & & & & & & &
\end{tabular}

Excluindo os trabalhadores não remunerados e aqueles produzindo para o próprio consumo ou trabalhando na construção para o próprio uso, a maioria dos jovens são empregados, existindo também uma grande proporção de mulheres trabalhando como empregada doméstica e homens trabalhando por conta-própria, sendo as proporções mais elevadas no meio urbano do que no rural. A proporção de empregados e trabalhadores por conta-própria é mais elevada para os jovens de 20 a 24 anos, atingindo uma proporção de $93,6 \%$ para homens e $73,5 \%$ para as mulheres na zona urbana.

De um modo geral, os jovens ingressam muito cedo no mercado de trabalho - na zona rural cerca de $72 \%$ (homens) e $60 \%$ (mulheres) dos jovens começam a trabalhar com até 12 anos de idade. Na zona urbana as porcentagens respectivas são $32,6 \%$ e $21,2 \%$, conforme pode ser visto na Tabela 6 . Observa-se, portanto, que na zona rural o ingresso no mundo do trabalho é muito precoce para a grande maioria dos jovens, 
onde quase três quartos deles tiveram seu primeiro trabalho aos 12 anos ou menos de idade. Pior ainda, cerca de um quarto dos jovens residentes na zona rural tiveram seu primeiro trabalho com menos de 10 anos de idade. Na zona urbana a situação é um pouco melhor, mas não deixa de ser grave pois quase um quarto dos jovens entraram no mercado de trabalho antes dos 13 anos de idade. Ademais, observa-se que os homens entram mais precocemente no mundo do trabalho do que as mulheres.

Tabela 6. Porcentagem de jovens de 15 a 24 anos de idade, estratificado por idade de ingresso no mercado de trabalho, situação de domicílio e sexo.

\begin{tabular}{lcccc}
\hline Idade em que começou & \multicolumn{2}{c}{ Urbano } & \multicolumn{2}{c}{ Rural } \\
\cline { 2 - 5 } a trabalhar & Homens & Mulheres & Homens & Mulheres \\
\hline Até 9 anos & 9,5 & 5,9 & 25,2 & 18,9 \\
$10-12$ anos & 23,1 & 15,3 & 47,2 & 41,5 \\
$13-15$ anos & 36,7 & 34,2 & 21,1 & 25,0 \\
$16-18$ anos & 24,1 & 31,4 & 5,3 & 11,1 \\
$19-21$ anos & 6,0 & 10,9 & 1,1 & 2,8 \\
22-24 anos & 0,7 & 2,2 & 0,2 & 0,7 \\
\hline
\end{tabular}

Fonte: PNAD/IBGE, 1998 (microdados).

Zylberstajn et al. (1985), a partir de dados da PNAD de 1976, encontraram porcentagens elevadas de jovens, de 15 a 17 anos, que ingressaram no mercado de trabalho muito cedo, cerca de $35 \%$ antes dos 13 anos de idade e $63 \%$ antes $\operatorname{dos} 15 \operatorname{anos}^{10}$.

A rotatividade dos jovens no mercado de trabalho é bastante alta, sendo o tempo de permanência do jovem em um mesmo trabalho geralmente muito curto. A Tabela 7 revela que grande parte dos jovens, com domicílio na zona urbana, fica no mesmo trabalho menos que um ano, 43,7\% dos jovens com 15 a 19 anos de idade e $31,2 \%$ dos jovens com idade entre 20 e 24 anos. Na zona urbana apenas 7,6\% e 14,6\% dos jovens na faixa etária de 15 a 19 e 20 a 24 anos de idade, respectivamente,

\footnotetext{
${ }^{10}$ Vale lembrar que a comparação entre as PNADs de 1976 e 1998 não é direta visto que a partir de 1990 a classificação de trabalho tornou-se mais abrangente. A partir de 1990 passou a ser considerado trabalho o exercício de ocupação econômica remunerada, ou ocupação econômica sem remuneração normalmente exercida durante pelo menos 1 hora por semana. Até 1990 o exercício regular de ocupação econômica sem remuneração só era considerado como trabalho quando exercida durante pelo menos 15 horas por semana.
} 
permanecem cinco anos ou mais no mesmo trabalho. Na zona rural o tempo de trabalho dos jovens é maior, quase $40 \%$ dos jovens de 15 a 24 anos permanecem no mesmo trabalho cinco anos ou mais.

Tabela 7. Tempo de trabalho dos jovens (empregados) na ocupação atual, estratificado por situação de domicílio, sexo e grupo de idade.

\begin{tabular}{lcccc}
\hline & \multicolumn{2}{c}{ Jovens de 15 a 19 anos } & \multicolumn{2}{c}{ Jovens de 20 a 24 anos } \\
\cline { 2 - 5 } Tempo de trabalho & Urbano & Rural & Urbano & Rural \\
\hline Menos de 1 ano & 43,7 & 20,1 & 31,2 & 21,2 \\
1 ano e menos de 2 anos & 22,4 & 10,2 & 20,7 & 13,0 \\
2 anos e menos de 5 anos & 26,3 & 31,1 & 33,6 & 26,2 \\
5 anos ou mais & 7,6 & 38,6 & 14,6 & 39,7 \\
Tempo médio (anos) & 1,4 & 3,7 & 2,2 & 4,3 \\
\hline
\end{tabular}

Fonte: PNAD/IBGE, 1998 (microdados).

A Tabela 7 permite observar que a duração do tempo de trabalho cresce com a idade, os jovens de 20 a 24 anos de idade residentes nas áreas urbanas permanecem no mesmo trabalho cerca $60 \%$ mais tempo que permanecem os jovens de 15 a 19 anos. Nas áreas rurais a diferença é apenas ligeiramente superior para os jovens de 20 a 24 anos.

Constatou-se nesta parte do trabalho que em 1998 havia no Brasil cerca de 30 milhões de jovens com idade entre 15 e 24 anos, dos quais $52 \%$ trabalhava. Verificou-se que a maioria dos jovens que trabalha mora nas áreas urbanas do país $(75,7 \%)$ e são homens $(62,2 \%)$ e, como esperado, a taxa de atividade dos jovens cresce com a idade. Portanto, foram encontradas indicações de que a taxa de atividade tende a ser maior nos grupos que têm acesso às melhores ofertas de emprego. Constatou-se também que a taxa de atividade dos jovens é mais elevada nas regiões mais ricas do país, o que indica que a atratividade do mercado de trabalho é um fator detenninante na decisão do jovem se inserir no mercado de trabalho. Por outro lado, a taxa de atividade é maior na zona rural do que na zona urbana, o que não deve estar relacionado à qualidade de emprego e sim ao fato de o trabalho rural ser mais intensivo em mão-de-obra não especializada do que o trabalho nas áreas urbanas. Constatou-se ainda que a taxa de atividade dos jovens é maior para os chefes de família, os quais tradicionalmente 
respondem pela maior parte do orçamento familiar, e maior para os negros, cujas famílias mais dependem se sua contribuição para sobreviver.

A análise dos dados da PNAD de 1998 mostrou que os jovens trabalhadores estão mais concentrados no mercado de trabalho informal, que a maioria dos jovens são empregados, existindo também uma grande proporção de mulheres trabalhando como empregada doméstica, sendo que alta porcentagem de jovens que não aufere nenhum rendimento pelo seu trabalho (cerca de 18\%). Verificou-se que os jovens brasileiros ingressam muito cedo no mercado de trabalho o que afeta em grande proporção sua escolarização. Por fim, constatou-se que os jovens permanecem por um curto período de tempo em um mesmo emprego, o que deve estar indicando que os jovens encaram seus empregos como temporários, visto a quase inexistência de perspectivas de crescimento na empresa estão sempre em busca de oportunidades melhores. Por outro lado, a maioria das empresas encara os jovens como mão-de-obra barata, cujos custos de contratação e demissão são relativamente mais baixos do que dos adultos.

\subsection{Escolaridade}

Uma questão importante com relação ao trabalho dos jovens é a possibilidade de conciliação do trabalho com o estudo, uma vez que o jovem geralmente só completa o primeiro grau, segundo grau e o curso superior aos 15, 18, 23 ou mais anos de idade, respectivamente. A Figura 4 mostra a porcentagem de jovens na escola segundo idade, sexo e se trabalham ou não. A Figura mostra que há, na escola, uma porcentagem maior de jovens que não trabalham em relação aos que trabalham, sendo a diferença muitas vezes bastante significativa, variando em torno de 12 a $23 \%$ para os homens e de 5 a $12 \%$ para as mulheres. 

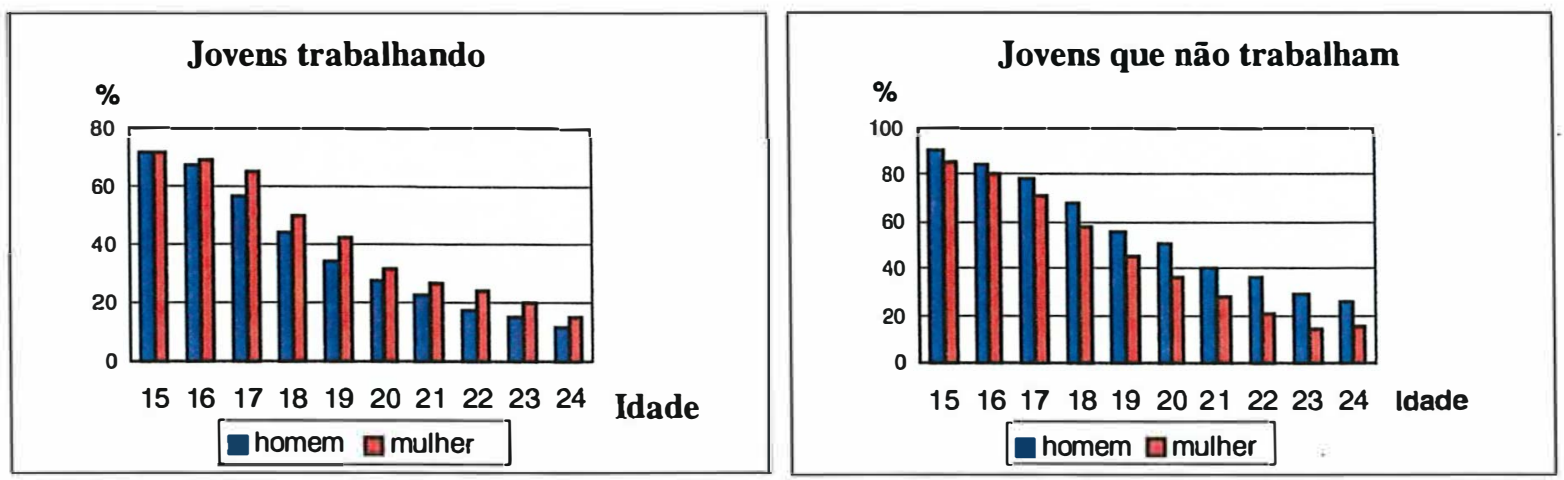

Figura 4 - Proporção de jovens na escola, trabalhando ou não, por sexo e setor (Fonte: PNAD, 1998).

A taxa de escolarização dos jovens é baixa, mesmo para o conjunto de jovens na faixa etária entre 15 e 17 anos, na qual os jovens deveriam estar ingressando no ensino médio. Para os jovens trabalhadores a porcentagem de jovens na escola varia de 50 a $75 \%$, já para os jovens que não trabalham a taxa de escolarização é mais favorável, estando em torno de $80 \%$. A partir dos 18 anos observa-se que a freqüência dos jovens à escola decresce acentuadamente para todos os grupos. Aos 20 anos apenas $35 \%$ dos jovens, em média, freqüenta escola e, aos 24 anos apenas uma minoria de $15 \%$.

Segundo Camarano (2000), aproximadamente $32 \%$ dos jovens brasileiros, com idade entre 18 e 24 anos, em 1998, freqüentavam a escola, sendo que aos 18 anos essa proporção era de $56 \%$ e aos 24 anos cai para apenas $16 \%$.

É interessante observar que a taxa de escolarização, entre os jovens que não trabalham, é maior para os homens do que para as mulheres. Para o grupo que trabalha observa-se tendência oposta. Visto que uma alta proporção de homens jovens trabalha, isto pode explicar o maior nível de escolaridade entre as mulheres comparativamente aos homens no Brasil.

Analisando conjuntamente as Tabela 3 e a Figura 4 observa-se que tanto a taxa de participação no mercado de trabalho como a taxa de não freqüência à escola cresce com a idade. Há vários estudos que procuram explicar essas relações. Conforme exposto por Barros e Mendonça (1991), as razões podem ser agrupadas em três 
categorias. A primeira explicação baseia-se na crescente atratividade, com a idade, do mercado de trabalho: os salários aumentam e a oferta de melhores empregos torna-se mais freqüente. Em segundo lugar, a compulsoriedade escolar se reduz com a idade e, a atratividade da escola tende a se reduzir, o que se deve tanto à repetência quanto à insatisfação ou à desilusão com o sistema educacional. E por último, a crescente independência com a idade acarreta não só uma maior demanda por um orçamento próprio, como também acesso a mais postos de trabalho. Os três fatores citados se complementam, traduzindo-se em crescente preferência do jovem pelo trabalho, sendo que, para a grande maioria dos jovens o trabalho passa a ser priorizado e o estudo passa a ser atividade secundária e noturna, quando não abandonada.

A Tabela 8, na qual está apresentado o número médio de anos de escolaridade completados pelos jovens que trabalham e não trabalham, permite observar se a participação do jovem no mercado de trabalho reduz o aproveitamento escolar. Os homens que não trabalham apresentam médias maiores que os homens que trabalham, entretanto as diferenças entre os dois grupos não são muito grandes. A maior diferença aparece para os homens de 21 anos do meio rural, havendo uma diferença de 1,3 no número médio de anos de escolaridade entre os grupos trabalhador e não-trabalhador.

Tabela 8. Número médio de anos de escolaridade entre jovens que trabalham e não trabalham, estratificado pela idade, sexo, e situação do domicílio.

\begin{tabular}{|c|c|c|c|c|c|c|c|c|}
\hline \multirow[b]{3}{*}{ Idade } & \multicolumn{4}{|c|}{ Jovens que trabalham } & \multicolumn{4}{|c|}{ Jovens que não trabalham } \\
\hline & \multicolumn{2}{|c|}{ Homens } & \multicolumn{2}{|c|}{ Mulheres } & \multicolumn{2}{|c|}{ Homens } & \multicolumn{2}{|c|}{ Mulheres } \\
\hline & Urbano & Rural & Urbano & Rural & Urbano & Rural & Urbano & Rural \\
\hline 15 & 5,5 & 3,6 & 6,1 & 4,4 & 5,7 & 4,4 & 6,1 & 4,6 \\
\hline 16 & 6,1 & 3,9 & 6,7 & 5,0 & 6,3 & 4,6 & 6,7 & 5,0 \\
\hline 17 & 6,5 & 4,1 & 7,4 & 4,9 & 6,9 & 5,1 & 7,4 & 5,1 \\
\hline 18 & 7,0 & 4,0 & 7,8 & 5,4 & 7,4 & 5,0 & 7,7 & 5,4 \\
\hline 19 & 7,3 & 3,9 & 8,0 & 5,4 & 7,7 & 4,7 & 7,7 & 5,3 \\
\hline 20 & 7,4 & 4,3 & 8,1 & 5,4 & 7,6 & 4,6 & 7,8 & 5,1 \\
\hline 21 & 7,5 & 4,3 & 8,2 & 5,5 & 7,7 & 5,6 & 7,6 & 5,2 \\
\hline 22 & 7,5 & 4,1 & 8,2 & 5,1 & 7,8 & 5,5 & 7,5 & 4,5 \\
\hline 23 & 7,7 & 4,0 & 8,1 & 4,8 & 7,8 & 5,2 & 7,0 & 4,7 \\
\hline 24 & 7,3 & 4,3 & 8,3 & 4,6 & 7,2 & 5,3 & 7,3 & 4,3 \\
\hline
\end{tabular}

Fonte: PNAD/IBGE, 1998 (microdados). 
Um resultado bastante interessante e inesperado é o fato das mulheres jovens trabalhadoras apresentarem maior média em anos de escolaridade que as não trabalhadoras, para as mulheres de 23 e 24 anos das áreas urbanas a diferença alcança um ano a mais de escolaridade para as trabalhadoras. A explicação pode estar na lógica de funcionamento do mercado de trabalho para as mulheres, onde são as mais escolarizadas que conseguem colocação no mercado. Tal resultado também pode estar evidenciando que o trabalho das mulheres lhes permite o acesso ao sistema escolar, tendo em vista que o estudo requer recursos financeiros, e o trabalho proporciona tal aporte. Ademais, as diferenças observadas no nível educacional não podem ser atribuídas somente ao fato de os jovens trabalharem ou não, uma vez que muitos outros fatores estão envolvidos, tais como renda familiar, escolaridade dos pais, tamanho da familia, etc.

Os dados evidenciam também que o perfil educacional das mulheres é, em geral, melhor que o dos homens, provavelmente em virtude da entrada mais precoce destes no mercado de trabalho. Observe que entre os jovens não trabalhadores, com idade a partir de 21 anos, os homens apresentam maior nível de escolaridade do que as mulheres, podendo a diferença atingir um ano, mas entre os trabalhadores a mulher apresenta maior escolaridade comparado aos homens.

A Figura 5 mostra que, para o grupo de jovens como um todo, o nível de escolaridade é melhor para o grupo de jovens não trabalhadores com 20 ou menos anos de idade. Um resultado interessante e não esperado é a média de anos de escolaridade maior para o grupo de jovens trabalhadores com 22 ou mais anos de idade comparado ao grupo de jovens não trabalhadores. 


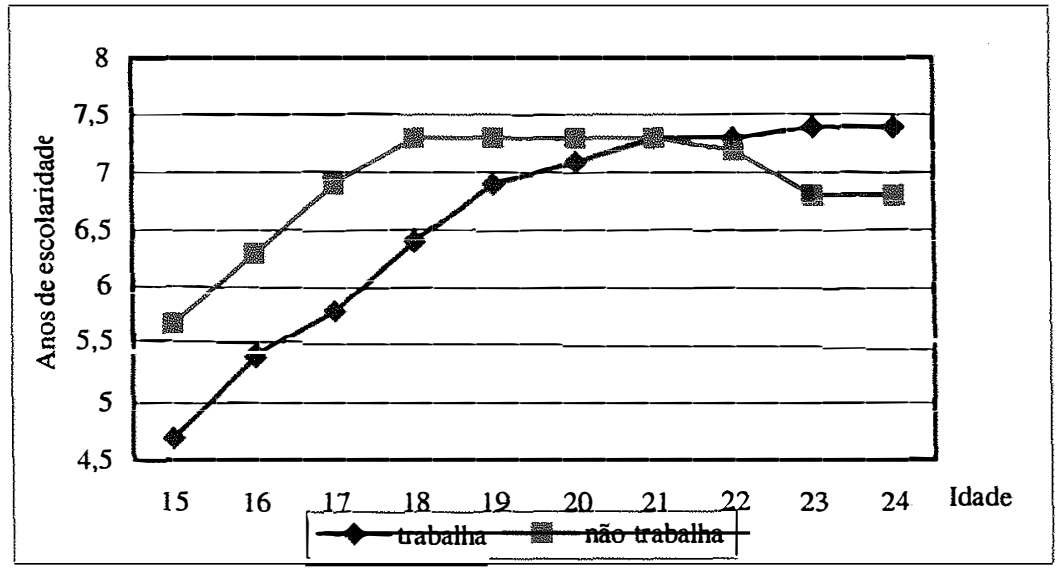

Figura 5 - Anos de escolaridade para jovens que trabalham ou não (Fonte: PNAD, 1998).

Outro importante determinante do nível de escolaridade dos jovens é a idade de ingresso no mercado de trabalho. De modo geral, quanto mais jovem se entra no mercado de trabalho, maiores são os efeitos adversos desse advento sobre a escolaridade dos indivíduos. A entrada precoce no mercado de trabalho geralmente reduz a oportunidade de uma boa educação, pois se sabe que crianças e jovens trabalhadores têm menor oportunidade de freqüentar escola regularmente, impedindo-os de obter um melhor trabalho e, conseqüentemente, aumento de rendimentos, mesmo na fase adulta da vida. Mesmo quando são capazes de freqüentar a escola, para muitas não sobra tempo para estudar, aumentando a repetência e a desistência. A Tabela 9 mostra que a média do número de anos de escolaridade varia inversamente com a idade em que os jovens de 15 a 24 anos de idade começaram a trabalhar. A escolaridade média dos jovens que começaram a trabalhar com idade de 19 a 21 anos chega a ser o dobro da escolaridade média daqueles que começaram a trabalhar com nove anos ou menos. 
Tabela 9. Anos de escolaridade dos jovens de 15 a 24 anos de idade, estratificado por idade de ingresso no mercado de trabalho, situação de domicílio e sexo.

\begin{tabular}{lcccc}
\hline \multirow{2}{*}{\begin{tabular}{c} 
Idade em que começou \\
\multicolumn{1}{c}{ a trabalhar }
\end{tabular}} & Homens & Mulheres & Homens & Mulheres \\
\cline { 2 - 4 } Até 9 anos & 5,3 & 6,1 & 3,6 & 4,4 \\
$10-12$ anos & 5,8 & 6,5 & 3,6 & 4,4 \\
$13-15$ anos & 6,9 & 7,6 & 4,4 & 5,5 \\
$16-18$ anos & 8,0 & 9,0 & 5,7 & 7,0 \\
$19-21$ anos & 9,2 & 10,0 & 7,7 & 8,3 \\
$22-24$ anos & 10,7 & 10,5 & 7,5 & 8,5 \\
\hline
\end{tabular}

Fonte: PNAD/IBGE, 1998 (microdados).

Seguindo esta linha, a baixa escolaridade, causada pela entrada precoce no mercado de trabalho, tem o efeito de limitar as oportunidades de emprego a postos de trabalho que não exigem qualificação e que dão baixa remuneração, mantendo o jovem dentro de um ciclo de pobreza já experimentado pelos pais. Barros et al. (2000), analisando dados da PNAD de 1998 e da Pesquisa sobre Padrões de Vida (PPV) de 1996-97, verificou que a inserção precoce de crianças e jovens de 5 a 17 anos no mercado de trabalho tem impactos deletérios sobre a escolaridade e a inserção futura das pessoas no mercado de trabalho. Observaram que o trabalho precoce apresenta efeito negativo indireto sobre a renda por meio do impacto exercido pela educação no rendimento da ocupação principal. Kassouf et al. (2001), usando dados do Brasil, PNAD de 1995, PPV de 1996-97 e a Pesquisa Nacional sobre Saúde e Nutrição (PNSN) de 1989, também mostraram que a entrada precoce no mercado de trabalho é fortemente associada a baixos níveis de escolaridade e renda, com os diferencias de renda perdurando na vida adulta. Ademais, também verificou o fato de que começar a trabalhar ainda criança ou muito jovem, prejudica a saúde em uma fase adulta da vida, mesmo controlando a escolaridade, idade, infra-estrutura do domicílio e outros fatores que afetam a saúde.

Dividindo a amostra de jovens em seis categorias, isto é, jovens que só estudam, só trabalham, estudam e trabalham, estudam e realizam atividades domésticas, só realizam atividades domésticas e não estudam nem trabalham, observa-se que a 
porcentagem de jovens que só estuda é muito baixa, tanto na zona urbana $(9,5 \%)$ quanto na zona rural $(3,2 \%)$. A maior proporção é a da categoria só trabalha, nas áreas rurais essa proporção atinge $44,2 \%$ e nas áreas urbanas 30,9\%. Observa-se, portanto, que a grande maioria dos jovens trabalha, combinando ou não o trabalho com o estudo, sendo a dedicação exclusiva ao estudo restrita a uma minoria de jovens (Figura 6).
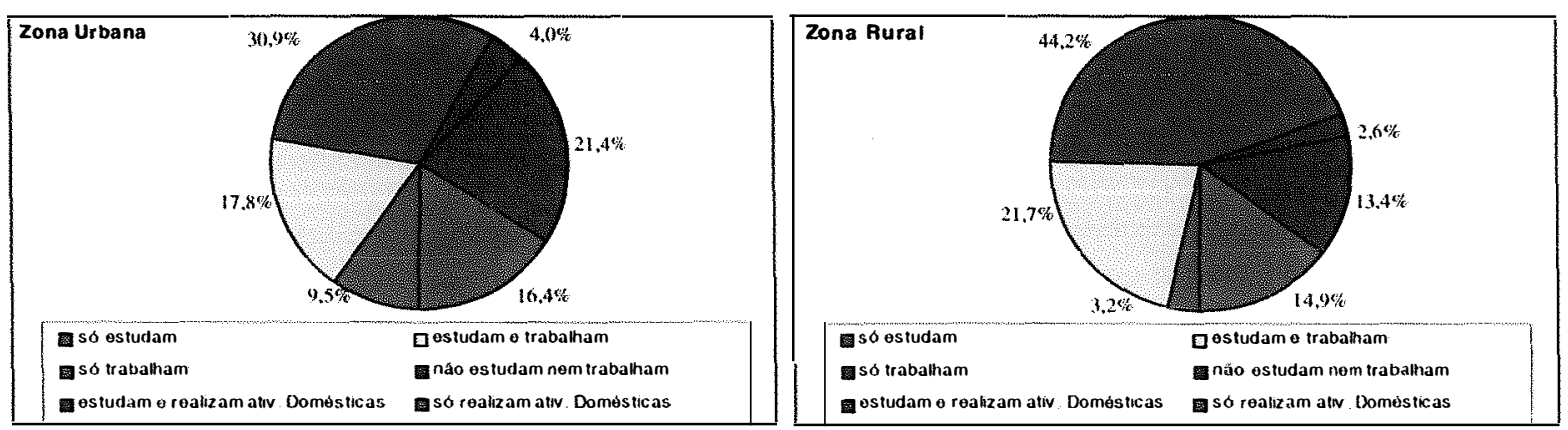

Figura 6 - Porcentagem de jovens de 15 a 24 anos em diferentes categorias (Fonte: PNAD, 1998).

Camarano (2000), estudando jovens com idade entre 18 e 24 anos, observou que aproximadamente $50 \%$ da população jovem masculina apenas trabalha, sendo os outros $50 \%$ bem distribuídos entre só estudam, estudam e trabalham e nem estudam e nem trabalham (16\%, 16\% e 18\% respectivamente). A maior parte das mulheres, de acordo com Camarano, não estuda nem trabalha (40\%), 27\% só trabalha, $20 \%$ só estuda e $13 \%$ estuda e trabalha.

Leme e Wajnman (2000), analisando o grupo de jovens com idade entre 15 e 19 anos, observaram que, em 1998, 36\% apenas estudavam e 30\% estudavam e trabalhavam.

A Tabela 10 mostra que existe uma relação inversa entre o nível de rendimento familiar e trabalho juvenil e relação direta entre nível de rendimento familiar e escolaridade, pois quanto maior o rendimento familiar mensal per capita, maior o percentual de jovens que só se dedicam ao estudo e menor o dos que só trabalham, bem como o dos que não freqüentam escola nem trabalham. 
Tabela 10. Distribuição percentual de jovens por situação de freqüência à escola e condição de atividade segundo o rendimento familiar mensal per capita (Salário Mínimo), excluindo o rendimento dos jovens, e grupos de idade.

\begin{tabular}{lcccccc}
\hline & \multicolumn{3}{c}{ Jovens de 15 a 19 anos } & \multicolumn{3}{c}{ Jovens de 20 a 24 anos } \\
\cline { 2 - 7 } & até 1/2 SM & $1 / 2-1 \mathrm{SM}$ & $>1 \mathrm{SM}$ & até $1 / 2 \mathrm{SM}$ & $1 / 2-1 \mathrm{SM}$ & $>1 \mathrm{SM}$ \\
\hline Só estudam & 29,5 & 43,1 & 57,2 & 5,4 & 9,7 & 16,6 \\
Estudam e trabalham & 23,8 & 22,9 & 21,0 & 9,5 & 12,1 & 19,4 \\
Só trabalham & 26,7 & 17,4 & 11,5 & 57,7 & 50,1 & 42,1 \\
$\begin{array}{l}\text { Não estudam nem } \\
\text { trabalham }\end{array}$ & 20,0 & 16,6 & 10,3 & 27,4 & 28,1 & 21,9 \\
\hline
\end{tabular}

Fonte: PNAD/ABGE, 1998 (microdados).

$\mathrm{Na}$ faixa etária de 15 a 19 anos observa-se que a porcentagem de jovens que só estudam com renda familiar mensal per capita maior que um salário mínimo $(57,2 \%)$ é o dobro da porcentagem de jovens que só estudam com renda familiar mensal de até $1 / 2$ salário mínimo (29,5\%). Entre os jovens com idade entre 20 e 24 anos a diferença entre os dois grupos é ainda maior, sendo que a porcentagem de jovens que só estudam que auferem mais que um salário mínimo mensal per capita é o triplo daqueles que auferem menos que meio salário mínimo mensal per capita.

Leme e Wajnmam (2000) dividiram a amostra de jovens, com idade entre 15 e 19 anos, em 10 faixas de renda objetivando analisar a influência do nível de renda na forma de alocação do tempo dos jovens. Constataram que a fração dos jovens que apenas estuda aumenta com a renda e que a porcentagem dos jovens que só trabalha é maior entre os mais pobres, enquanto não estudar nem trabalhar atinge igualmente os jovens nas cinco primeiras faixas de renda. A porcentagem de jovens que trabalham $\mathrm{e}$ estudam não apresentou comportamento monótono com a renda.

Uma importante questão deste trabalho é a de saber em que medida a escolarização dos jovens é afetada pelo seu trabalho e quanto à frequiência à escola afeta a participação do jovem no mercado de trabalho. Para tanto se faz necessário pesquisar, com detalhe, a intensidade com que os jovens participam do mercado de trabalho. A 
Tabela 11 mostra a porcentagem de jovens que trabalham por número de horas trabalhadas semanalmente. Os dados mostram que, de modo geral, a carga de trabalho é elevada para todos os jovens. Considerando-se 40 horas por semana como atividade em tempo integral, que a maioria dos jovens está nesse caso, variando de $54 \%$ a $87 \%$ para os homens e de $38 \%$ a $70 \%$ para as mulheres. Observa-se ainda, a existência de uma proporção substancial de jovens com sobrecarga de trabalho, ou seja, trabalhando mais do que às 44 horas semanais previstas pela legislação trabalhista. Entre os jovens com idade entre 15 e 19 anos, mais de $35 \%$ trabalham em demasia na zona urbana e mais de $25 \%$ na zona rural. Entre os jovens de 20 a 24 anos, a sobrecarga de trabalho é maior, atinge quase $50 \%$ dos homens e mais de $25 \%$ das mulheres. A última linha da Tabela 11 reporta o número médio de horas semanais de trabalho dos jovens. Os homens trabalham maior número de horas que as mulheres e os jovens da área urbana trabalham maior número de horas do que os da área rural. Ademais, os dados indicam que a carga horária de trabalho aumenta com a idade.

Tabela 11. Porcentagem de jovens trabalhando, estratificada pelo número de horas de trabalho semanais, por situação de domicílio, sexo e grupo de idade.

\begin{tabular}{ccccccccc}
\hline & \multicolumn{3}{c}{ Jovens de 15 a 19 anos } & \multicolumn{3}{c}{ Jovens de 20 a 24 anos } \\
\cline { 2 - 8 } Horas/semana & \multicolumn{2}{c}{ Homens } & \multicolumn{2}{c}{ Mulheres } & \multicolumn{2}{c}{ Homens } & \multicolumn{2}{c}{ Mulheres } \\
\cline { 2 - 8 } & Urbano & Rural & Urbano & Rural & Urbano & Rural & Urbano & Rural \\
\hline$(1-19]$ & 5,8 & 7,8 & 9,1 & 23,6 & 2,5 & 2,6 & 7,0 & 23,5 \\
$(19-39]$ & 21,2 & 38,8 & 25,1 & 38,2 & 10,3 & 17,5 & 22,8 & 36,0 \\
$(39-44]$ & 35,6 & 27,1 & 30,5 & 16,3 & 39,7 & 31,2 & 35,9 & 19,3 \\
$>44$ & 37,4 & 27,1 & 35,4 & 21,9 & 47,5 & 48,8 & 34,3 & 21,6 \\
Média & 40,7 & 36,0 & 39,1 & 30,3 & 45,0 & 43,8 & 39,9 & 30,6 \\
\hline
\end{tabular}

Fonte: PNAD/IBGE, 1998 (microdados).

Para verificar quanto a freqüência à escola afeta a participação do jovem no mercado de trabalho, dividiu-se a amostra de jovens trabalhadores em duas, de acordo com a freqüência escolar. Observa-se na Tabela 12 que a escolarização dos jovens têm forte relação com o número de horas trabalhadas. Para os jovens que freqüentam escola, a incidência de trabalho em tempo integral varia de 33 a $78 \%$, enquanto para aqueles que 
não freqüentam escola a porcentagem de jovens trabalhando em tempo integral chega a atingir $90 \%$.

Tabela 12. Porcentagem de jovens trabalhando, estratificada pelo número de horas de trabalho semanais, por situação de domicílio, sexo e grupo de idade e se frequientam ou não escola.

\begin{tabular}{|c|c|c|c|c|c|c|c|c|}
\hline \multirow[b]{3}{*}{ Horas/semana } & \multicolumn{4}{|c|}{ Jovens de 15 a 19 anos } & \multicolumn{4}{|c|}{ Jovens de 20 a 24 anos } \\
\hline & \multicolumn{2}{|c|}{ Homens } & \multicolumn{2}{|c|}{ Mulheres } & \multicolumn{2}{|c|}{ Homens } & \multicolumn{2}{|c|}{ Mulheres } \\
\hline & Urbano & Rural & Urbano & Rural & Urbano & Rural & Urbano & Rural \\
\hline & \multicolumn{8}{|c|}{ Jovens que não freqüentam escola } \\
\hline$(1-19]$ & 3,0 & 3,4 & 6,2 & 24,1 & 1,9 & 2,0 & 7,0 & 25,6 \\
\hline$(19-39]$ & 13,0 & 23,7 & 17,4 & 32,2 & 8,4 & 15,5 & 19,9 & 34,4 \\
\hline$(39-44]$ & 35,6 & 35,7 & 32,7 & 17,1 & 38,3 & 31,4 & 35,8 & 18,9 \\
\hline$>44$ & 48,4 & 37,2 & 43,7 & 26,6 & 51,4 & 51,1 & 37,3 & 21,1 \\
\hline \multirow[t]{2}{*}{ Média } & 44,5 & 41,0 & 42,7 & 32,0 & 46,1 & 44,7 & 40,8 & 30,2 \\
\hline & \multicolumn{8}{|c|}{ Jovens que freqüentam escola } \\
\hline$(1-19]$ & 8,0 & 12,3 & 10,9 & 23,1 & 4,6 & 6,1 & 7,0 & 11,2 \\
\hline$(19-39]$ & 28,0 & 53,1 & 30,1 & 44,4 & 17,5 & 29,6 & 31,3 & 44,3 \\
\hline$(39-44]$ & 35,6 & 18,0 & 29,1 & 15,4 & 45,1 & 29,5 & 36,3 & 21,9 \\
\hline$>44$ & 28,4 & 16,5 & 29,8 & 17,1 & 32,8 & 34,8 & 25,4 & 22,6 \\
\hline Média & 37,6 & 30,8 & 36,7 & 28,5 & 40,7 & 38,4 & 37,2 & 32,7 \\
\hline
\end{tabular}

Fonte: PNAD/IBGE, 1998 (microdados).

Ademais, observa-se que a incidência de sobrecarga de trabalho é significativamente maior entre os jovens que não freqüentam escola. A proporção de jovens que trabalham mais de 44 horas semanais e não freqüentam a escola é cerca de $50 \%$ maior que a proporção de jovens com sobrecarga de trabalho que freqüentam escola. A média de horas trabalhadas por semana é sempre maior para os jovens que não estudam, exceto para as mulheres de 20 a 24 anos residentes na zona rural, sendo que a diferença de horas trabalhadas entre os dois grupos varia de 3,5 a 10 horas.

Pode-se então afirmar que os jovens enfrentam uma longa jornada em seu dia a dia. Mais de 60\% (zona urbana) e cerca de $40 \%$ (zona rural) dos jovens, diariamente, têm uma dura jornada de 12-14 horas ou mais, quando se conta 8 horas para o trabalho, 4 horas para a escola e cerca de 2 horas para o transporte. De modo geral, verifica-se que o trabalho dos jovens impõe-lhes extensas jornadas diárias, o que 
compromete severamente os que freqüentam a escola e dificulta o acesso para os que não freqüentam e nela desejam entrar ou retornar. Desta forma, há indicações de que a reprovação e a evasão, tão freqüentes no sistema escolar brasileiro, estejam intimamente relacionadas ao trabalho do jovem.

Observa-se, portanto que, de modo geral, a taxa de escolaridade e consequentemente o nível de escolaridade dos jovens trabalhadores é significativamente menor do que dos jovens que não trabalham. Ademais, a taxa de analfabetismo era, em 1998 , de $5 \%$ entre os jovens não trabalhadores e de $6 \%$ entre os jovens trabalhadores. Mesmo admitindo-se que as diferenças de níveis educacionais entre jovens trabalhadores e não trabalhadores estão relacionados também com o nível de renda familiar, a escolaridade dos pais e o tamanho da familia, etc.. não há como negar que o trabalho prejudica a escolarização dos jovens. Entretanto, a grande maioria dos jovens precisa do trabalho para a própria subsistência ou de sua família. Isso compromete o futuro desses jovens, os quais devem reproduzir as condições sociais vigentes, onde os mais pobres têm menos escolaridade e trabalham mais. Como equacionar este problema ainda é uma incógnita, mas sabe-se que, pela sua importância, precisa ser enfrentado e superado no Brasil.

Em 1998 havia no país um milhão e seiscentos mil de jovens analfabetos, os quais nunca freqüentaram a escola ou abandonaram os estudos e que são esquecidos pelas políticas formuladas pelo governo, as quais privilegiam a erradicação do analfabetismo infantil e se esquecem que os jovens têm pela frente toda uma vida. Para aumentar a igualdade de renda e a mobilidade social é fundamental investimento contínuo na expansão da educação que priorize não somente as crianças, mas também dê especial atenção aos jovens brasileiros, garantido-lhes ao menos o ensino médio (antigo $2^{0}$ grau). O Ministério da Educação (MEC) precisa ampliar os investimentos feitos na reforma do ensino médio e profissionalizante, expansão do ensino técnico profissional e na criação de programas de aceleração de estudos que possibilitem aos jovens, trabalhadores e não trabalhadores, melhorarem seu nível de escolaridade. 


\subsection{A remuneração do trabalho}

A Tabela 13 mostra que os rendimentos auferidos pelos jovens são baixos. $\mathrm{Na}$ área urbana mais de $50 \%$ dos jovens de 15 a 19 e cerca de $30 \%$ de 20 a 24 anos de idade auferem um Real ou menos por hora ${ }^{11}$. Na área rural essas porcentagens são significativamente mais elevadas, sendo $80 \%$ e $60 \%$ para jovens com idade entre $15-19$ e 20-24, respectivamente.

Tabela 13. Porcentagem de jovens trabalhando e recebendo pagamento, estratificada pelo rendimento por hora, situação de domicílio, sexo e grupo de idade.

\begin{tabular}{ccccccccc}
\hline \multirow{2}{*}{$\begin{array}{c}\text { Rendim/hora } \\
\text { (Reais) }\end{array}$} & \multicolumn{3}{c}{ Jovens de 15 a 19 anos } & \multicolumn{3}{c}{ Jovens de 20 a 24 anos } \\
\cline { 2 - 9 } & \multicolumn{2}{c}{ Homens } & \multicolumn{2}{c}{ Mulheres } & \multicolumn{2}{c}{ Homens } & \multicolumn{2}{c}{ Mulheres } \\
\hline$(0,0-0,5]$ & 12,7 & 31,5 & 17,9 & 43,1 & 4,1 & 18,0 & 7,1 & 24,1 \\
$(0,5-1,0]$ & 40,3 & 48,7 & 37,8 & 38,1 & 22,3 & 44,7 & 24,8 & 35,5 \\
$(1,0-2,0]$ & 34,8 & 15,8 & 32,7 & 15,3 & 38,2 & 26,9 & 37,6 & 26,4 \\
$(2,0-3,0]$ & 7,5 & 2,6 & 7,0 & 1,9 & 16,5 & 6,5 & 14,2 & 8,9 \\
$(3,0-4,0]$ & 2,1 & 0,7 & 2,2 & 0,6 & 8,6 & 2,2 & 6,5 & 2,7 \\
$(4,0-5,0]$ & 1,1 & 0,1 & 0,9 & 0,4 & 4,1 & 0,6 & 3,8 & 1,4 \\
$>5,0$ & 1,5 & 0,6 & 1,5 & 0,6 & 6,2 & 1,1 & 6,0 & 1,0 \\
Média & 1,28 & 0,82 & 1,21 & 0,76 & 2,23 & 1,12 & 2,07 & 1,18 \\
\hline Fonte: PNAD/BGEE, 1998 (microdados). & \multicolumn{3}{l}{. } \\
\hline
\end{tabular}

A última linha da Tabela 13 mostra o rendimento médio, em Reais, por hora. As médias são sempre maiores na área urbana que na rural, sendo que o rendimento auferido na zona rural é cerca de $60 \%$ do rendimento auferido na zona urbana. O rendimento dos jovens de 20 a 24 anos de idade é significativamente superior ao dos jovens com idade entre 15 e 19 anos, sendo na zona urbana $70 \%$ maior para homens e mulheres e na zona rural $36 \%$ superior para os homens e $55 \%$ superior para as mulheres. Ademais, os rendimentos dos homens são ligeiramente superiores ao das mulheres.

A Tabela 14 apresenta as porcentagens de jovens que trabalham de acordo com o salário mensal recebido. Apesar de haver um salário mínimo legal no Brasil (fixado em $\mathrm{R} \$ 130,00$ por mês em setembro de 1998), uma parcela substancial dos 
jovens recebe menos que 1 salário por mês. Na zona rural cerca de $60 \%$ e na zona urbana mais de $25 \%$ dos jovens com idade entre 15 e 19 anos recebem menos de um salário mínimo. Mesmo para a faixa etária entre 20 e 24 anos há uma proporção elevada de jovens que recebem menos que o salário estabelecido legalmente, alcançando $44 \% \mathrm{e}$ $14 \%$ dos jovens na área rural e urbana, respectivamente.

Tabela 14. Porcentagem de jovens trabalhando e recebendo pagamento, estratificada pelo salário mínimo mensal, por situação de domicilio, sexo e grupo de idade.

\begin{tabular}{ccccccccc}
\hline \multirow{2}{*}{$\begin{array}{c}\text { Salário } \\
\text { mínimo }\end{array}$} & \multicolumn{3}{c}{ Jovens de 15 a 19 anos } & \multicolumn{3}{c}{ Jovens de 20 a 24 anos } \\
\cline { 2 - 9 } mensal & \multicolumn{2}{c}{ Homens } & \multicolumn{2}{c}{ Mulheres } & \multicolumn{2}{c}{ Homens } & \multicolumn{2}{c}{ Mulheres } \\
\cline { 2 - 9 } & Urbano & Rural & Urbano & Rural & Urbano & Rural & Urbano & Rural \\
\hline$<1,0$ & 25,9 & 56,5 & 32,9 & 63,6 & 8,3 & 35,1 & 14,3 & 43,3 \\
$=1,0$ & 17,0 & 12,6 & 21,3 & 15,8 & 8,1 & 13,0 & 15,1 & 19,2 \\
$(1,0-2,0]$ & 35,7 & 24,0 & 30,2 & 17,1 & 31,6 & 33,2 & 32,3 & 23,6 \\
$(2,0-3,0]$ & 13,5 & 4,0 & 11,1 & 2,6 & 20,2 & 9,6 & 18,3 & 8,5 \\
$(3,0-4,0]$ & 5,3 & 1,9 & 2,6 & 0,9 & 15,1 & 5,8 & 10,2 & 3,3 \\
$>4,0$ & 2,6 & 1,0 & 1,9 & 0,1 & 16,7 & 3,2 & 9,7 & 2,1 \\
\hline
\end{tabular}

Fonte: PNAD/IBGE, 1998 (microdados).

No Brasil existe também uma porcentagem significativa de adultos que recebem menos do que o salário mínimo legal. Na zona urbana, há 5,3\% dos homens e $14 \%$ das mulheres com idade entre 25 a 64 anos que auferem menos que o salário mínimo, enquanto na zona rural as porcentagens aumentam para $31,1 \%$ de homens e 46,6\% de mulheres. Essas proporções são bastante próximas daquelas encontradas para os jovens de 20 a 24 anos. A grande diferença entre os adultos e os jovens está nos níveis mais elevados de renda. Quase 60\% de homens e 35\% de mulheres adultas na área urbana e $18 \%$ de homens e $10 \%$ de mulheres adultas na área rural auferem mais de três salários mínimos mensais. Comparando estes dados com os dados da Tabela 15 observa-se que a proporção de adultos que aufere mais de três salários mínimos mensais é cerca do dobro da porcentagem de jovens de 20 a 24 anos.

11 O salário mínimo mensal no Brasil, em outubro de 1998, era de $\mathrm{R} \$ 130,00$. Assim sendo, considerando 44 horas de trabalho por semana, o salário mínimo por hora seria de $\mathrm{R} \$ 0,7386$. 
Diversos autores demonstraram a existência de diferencial de rendimentos entre os setores formal e informal da economia, ver entre outros [Kassouf (1998), Silva (1997), Marcouiller et al. (1997), Fernandes (1996), Tienfenthaler (1994), Pero (1994)]. Todos os estudos concluíram que os trabalhadores do setor formal encontram-se em melhor situação que os trabalhadores informais, sendo as diferenças nos rendimentos auferidos pelos dois grupos de trabalhadores bastante significativas. A Tabela 15 mostra o rendimento médio em Reais (por hora trabalhada) para os setores formal, informal e empregadores. Os dados confirmam o dito acima, ou seja, os trabalhadores informais auferem rendimentos inferiores ao do setor formal. $\mathrm{Na}$ zona urbana o rendimento dos trabalhadores informais são cerca de $70 \%$ dos rendimentos auferidos pelos trabalhadores formais, na zona rural os trabalhadores informais auferem cerca de $60 \%$ (homens) e 50\% (mulheres) dos rendimentos dos trabalhadores formais. Os diferenciais de rendimentos entre os setores formal e informal são menores entre os jovens do que entre os adultos, exceto para homens urbanos.

Tabela 15. Rendimento médio (por hora trabalhada) estratificado por setor, situação de domicílio, sexo e grupo de idade, valores expressos em Reais.

\begin{tabular}{lcccccccc}
\hline & \multicolumn{3}{c}{ Jovens de 15 a 24 anos } & \multicolumn{3}{c}{ Adultos de 25 a 64 anos } \\
\cline { 2 - 9 } Setor & Homens & \multicolumn{3}{c}{ Mulheres } & \multicolumn{2}{c}{ Homens } & \multicolumn{2}{c}{ Mulheres } \\
\cline { 2 - 9 } & Urbano & Rural & Urbano & Rural & Urbano & Rural & Urbano & Rural \\
\hline Setor Formal & 2,14 & 1,37 & 2,00 & 1,51 & 4,71 & 2,24 & 3,87 & 2,33 \\
Setor Informal & 1,49 & 0,87 & 1,44 & 0,78 & 3,48 & 1,30 & 2,49 & 1,20 \\
Empregadores & 7,13 & 2,15 & 7,37 & 8,95 & 11,19 & 4,97 & 9,44 & 5,66 \\
\hline
\end{tabular}

Fonte: PNAD/IBGE, 1998 (microdados).

A Tabela 16 mostra a relação entre os níveis de escolaridade e o rendimento médio dos jovens e adultos. Os resultados obtidos são os esperados, ou seja, com o aumento no nível de escolaridade o rendimento médio eleva-se para todos os grupos. 
Tabela 16. Rendimento médio (por hora trabalhada) estratificado por anos de escolaridade, situação de domicílio, sexo e grupos de idade, valores expressos em Reais.

\begin{tabular}{lcccccccc}
\hline & \multicolumn{3}{c}{ Jovens de 15 a 24 anos } & \multicolumn{3}{c}{ Adultos de 25 a 64 anos } \\
\cline { 2 - 9 } & \multicolumn{3}{c}{ Homens } & \multicolumn{3}{c}{ Mulheres } & \multicolumn{3}{c}{ Homens } & \multicolumn{3}{c}{ Mulheres } \\
\cline { 2 - 9 } Escolaridade & Urbano & Rural & Urbano & Rural & Urbano & Rural & Urbano & Rural \\
\hline Sem instrução e & & & & & & & & \\
menos de 1 ano & 1,01 & 0,64 & 0,84 & 0,55 & 1,56 & 0,91 & 1,23 & 0,93 \\
1 a 3 anos & 1,06 & 0,80 & 0,92 & 0,61 & 2,12 & 1,29 & 1,44 & 0,97 \\
4 a 7 anos & 1,37 & 1,05 & 1,04 & 0,77 & 2,79 & 1,79 & 1,77 & 1,29 \\
8 a 10 anos & 1,94 & 1,43 & 1,45 & 1,11 & 3,72 & 2,74 & 2,44 & 1,55 \\
11 a 14 anos & 3,02 & 2,11 & 2,48 & 1,94 & 6,03 & 4,52 & 4,07 & 3,02 \\
15 anos ou mais & 6,45 & 6,91 & 5,35 & 5,42 & 15,56 & 12,70 & 9,25 & 8,72 \\
\hline Fonte: PNAD/IBGE, 1998 (microdados). & & & & & &
\end{tabular}

O rendimento dos jovens varia de $41 \%$ a $70 \%$ do rendimento auferido pelos adultos. Os diferenciais de rendimento entre jovens e adultos aumentam com o nível de escolaridade, indicando que em postos de trabalho que exigem pouca ou nenhuma qualificação, os jovens, que geralmente ainda não completaram a sua escolarização básica, são remunerados com maior igualdade em relação aos adultos.

$\mathrm{O}$ aumento dos rendimentos para os trabalhadores jovens com o $2^{\circ}$ grau completo em comparação àqueles com apenas 8 a 10 anos de estudo pode atingir até $44 \%$. O aumento de rendimento para aqueles que terminam o curso superior em relação aos trabalhadores com $2^{\circ}$ grau completo chega a $75 \%$.

O Brasil é um país extenso e bastante heterogêneo no que diz respeito às características sócio-econômicas de suas regiões. A Tabela 17 permite observar diferenças entre os rendimentos dos trabalhadores residentes nas regiões industrializadas e modernas e daqueles trabalhadores residentes nas regiões menos desenvolvidas.

Observa-se que os rendimentos médios entre as regiões são bastante diferentes (é importante ressaltar que estes rendimentos não foram ajustados para refletir as diferenças que possam existir no custo de vida das regiões). Os rendimentos são notavelmente mais baixos nas regiões Norte e Nordeste para todos os grupos de 
trabalhadores. O rendimento dos jovens varia de 36\% (homens com domicílio urbano residentes na região Centro-Oeste) a 87\% (mulheres residentes na zona rural da região Norte) do rendimento auferido pelos adultos.

Tabela 17. Rendimento médio (por hora trabalhada) estratificado por regiões, situação de domicílio, sexo e grupos de idade, valores expressos em Reais.

\begin{tabular}{|c|c|c|c|c|c|c|c|c|}
\hline & \multicolumn{4}{|c|}{ Jovens de 15 a 24 anos } & \multicolumn{4}{|c|}{ Adultos de 25 a 64 anos } \\
\hline & \multicolumn{2}{|c|}{ Homens } & \multicolumn{2}{|c|}{ Mulheres } & \multicolumn{2}{|c|}{ Homens } & \multicolumn{2}{|c|}{ Mulheres } \\
\hline & Urbano & Rural & Urbano & Rural & Urbano & Rural & Urbano & Rural \\
\hline Sudeste & 2,19 & 1,25 & 2,00 & 1,12 & 5,23 & 1,94 & 3,89 & 1,71 \\
\hline Sul & 1,95 & 1,27 & 1,83 & 1,22 & 4,67 & 1,88 & 3,35 & 1,84 \\
\hline Centro-Oeste & 1,71 & 1,19 & 1,67 & 1,36 & 4,80 & 2,26 & 3,51 & 2,44 \\
\hline Norte & 1,40 & 0,98 & 1,38 & 1,18 & 3,47 & 1,31 & 2,85 & 1,36 \\
\hline Nordeste & 1,23 & 0,74 & 1,19 & 0,77 & 3,01 & 1,24 & 2,37 & 1,33 \\
\hline
\end{tabular}

Fonte: PNAD/IBGE, 1998 (microdados).

Os diferenciais de rendimentos entre jovens e adultos são maiores entre os trabalhadores urbanos comparativamente aos trabalhadores rurais. Parece existir uma relação entre baixos rendimentos e taxas de rendimento jovem/adulto mais elevada, indicando menor diferença entre os rendimentos entre jovens e adultos na zona rural. Estes resultados podem em parte ser explicados pelo fato de existir, na zona rural, uma maior concentração de trabalhadores nos extratos de renda mais baixos, de modo que tanto os jovens quanto os adultos auferem baixos rendimentos. Na zona rural, as oportunidades de se alcançar postos de trabalho mais elevados, de modo a elevar o rendimento médio, são escassos tanto para jovens como para adultos, não existindo assim, uma variabilidade muito grande entre os rendimentos dos jovens e dos adultos para a maior parte dos trabalhadores.

A Tabela 18 mostra a porcentagem de domicílios com jovens trabalhando cujos rendimentos contribuem para certa porcentagem da renda familiar. A contribuição dos rendimentos dos jovens na renda familiar é muito importante. Os jovens de 15 a 19 anos contribuem com mais de $30 \%$ da renda familiar em $44,5 \%$ dos domicílios urbanos e em 55\% dos domicílios rurais. Os jovens de 20 a 24 anos contribuem com mais de $30 \%$ da renda familiar em $67,8 \%$ dos domicílios urbanos e em $74,4 \%$ dos domicílios rurais. 
Os jovens de 15 a 19 anos contribuem com mais de $50 \%$ da renda familiar em $20 \%$ das famílias. Já a contribuição dos jovens de 20 a 24 anos com mais de $50 \%$ da renda familiar se dá em mais de $40 \%$ das família.

Tabela 18. Porcentagem de famílias em que os rendimentos dos jovens contribuem para certa porcentagem da renda familiar, estratificada por situação de domicílios e grupos de idade.

\begin{tabular}{ccccc}
\hline Contribuição (\%) dos & \multicolumn{4}{c}{ Porcentagem de domicílios } \\
\cline { 2 - 5 } rendimentos dos jovens na & \multicolumn{3}{c}{ Jovens de 15 a 19 anos } & Jovens de 20 a 24 anos \\
\cline { 2 - 5 } renda domiciliar & Urbano & Rural & Urbano & Rural \\
\hline$(0-10]$ & 12,9 & 7,7 & 5,5 & 2,8 \\
$(10-20]$ & 22,6 & 15,4 & 11,7 & 9,9 \\
$(20-30]$ & 20,1 & 21,8 & 15,0 & 12,9 \\
$(30-40]$ & 15,7 & 19,5 & 14,0 & 15,3 \\
$(40-50]$ & 10,6 & 14,7 & 11,7 & 11,0 \\
$(50-60]$ & 4,5 & 6,3 & 6,6 & 6,4 \\
$(60-70]$ & 2,8 & 4,1 & 5,4 & 4,1 \\
$(70-80]$ & 1,3 & 1,3 & 3,0 & 2,9 \\
$(80-90]$ & 0,4 & 0,3 & 1,4 & 0,7 \\
$(90-100]$ & 9,2 & 8,8 & 25,7 & 34,0 \\
\hline
\end{tabular}

Fonte: PNAD/IBGE, 1998 (microdados).

Os jovens de 15 a 19 anos são responsáveis por mais de $90 \%$ do rendimento familiar em quase $10 \%$ dos domićlios. Esse percentual alcança $26 \%$ e $34 \%$ dos domicílios, quando se considera a contribuição dos jovens de 20 a 24 anos, na zona urbana e rural, respectivamente. Para entender porque a contribuição destes jovens é tão elevada analisou-se separadamente a posição destes jovens no domicílio. Para este segmento populacional específico verificou-se que $99,4 \%$ dos jovens de 15 a 19 anos de idade eram chefes. Entre os jovens com idade entre 20 e 24 anos $95 \%$ e $88 \%$ eram chefes, na zona rural e urbana, respectivamente.

Observa-se que apesar do baixo rendimento dos jovens a sua contribuição na renda familiar é muito importante. Portanto pode-se dizer que a principal razão para os jovens trabalharem é a necessidade de complementar a renda familiar, ou seja, as famílias lançam seus jovens no mercado de trabalho na busca de uma sobrevivência 
digna, o que para muitas famílias brasileiras não se torna realidade mesmo contando com os rendimentos auferidos pelos seus jovens. Em 1998 existia no Brasil, segundo Canuto (2000), mais de 50 milhões de pessoas vivendo abaixo da linha de pobreza. Estão abaixo da linha de pobreza aquelas pessoas que não possuem renda suficiente para garantir o mínimo considerado indispensável para a sobrevivência digna, que inclui alimentação, vestuário, habitação e transportes. Para o Brasil como um todo, este mínimo é considerado por muitos autores como sendo meio salário mínimo, o que pode variar de região para região, visto que o Brasil é um país extenso e bastante heterogêneo no que diz respeito às sua condições sócio-econômicas.

Portanto, os jovens encontram-se numa situação bastante difícil. Por um lado precisam trabalhar para complementar a renda familiar ou até mesmo para auferir a única renda da familia, o que acontece em muitos lares brasileiros, onde a única fonte de renda é obtida pelos membros jovens. Por outro lado há fortes indícios de que o rabalho do jovem prejudica a sua escolarização, como já foi dito anteriormente, o que deverá impedi-lo de obter um melhor trabalho e, consequentemente, aumento de rendimentos, mesmo na fase adulta da vida. Este é um grave dilema enfrentado pelos jovens, ou seja, a necessidade de auferir alguma renda é tão grande que o trabalho passa a ser priorizado e o estudo torna-se atividade secundária e noturna, quando não abandonada.

\subsection{Características familiares}

A Tabela 19 mostra que o trabalho dos jovens de 15 a 19 anos de idade está relacionado com a renda per capita de suas famílias. Na zona urbana, $52 \%$ dos jovens que rabalham encontram-se em famílias em que a renda mensal per capita é no máximo 100 Reais, entre os jovens que não trabalham essa proporção decresce para $42 \%$. Na zona rural essas proporções são respectivamente 84 e $77 \%$. Para os jovens com idade entre 20 e 24 anos não se observa esta tendência, o que pode ser explicado pelo momento no ciclo de vida destes jovens. O principal motivo para estes jovens trabalharem não é para complementar a renda familiar, muitos dos homens jovens já são 
chefes de família (28,5\%), sendo que destes, $92 \%$ trabalham, e uma porcentagem significativa das mulheres já se tornou mãe $(46,1 \%)$, das quais $40 \%$ rabalham.

Tabela 19. Porcentagem de jovens trabalhando ou não, de acordo com a renda familiar per capita, excluindo os rendimentos dos jovens, estratificada pela situação do domicílio e grupos de idade.

\begin{tabular}{ccccccccc}
\hline Renda familiar & \multicolumn{3}{c}{ Jovens de 15 a 19 anos } & \multicolumn{3}{c}{ Jovens de 20 a 24 anos } \\
\cline { 2 - 8 } mensal & \multicolumn{2}{c}{ Trabalham } & Não trabalham & \multicolumn{2}{c}{ Trabalham } & Não trabalham \\
\cline { 2 - 8 } per capita (Reais) & Urbano & Rural & Urbano & Rural & Urbano & Rural & Urbano & Rural \\
\hline$(0-25]$ & 13,6 & 29,4 & 9,6 & 22,1 & 28,5 & 38,6 & 23,0 & 31,9 \\
$(25-50]$ & 13,9 & 30,6 & 11,1 & 25,5 & 9,8 & 20,9 & 10,6 & 23,3 \\
$(50-75]$ & 12,5 & 15,8 & 10,8 & 17,3 & 8,9 & 13,8 & 10,1 & 15,4 \\
$(75-100]$ & 11,7 & 8,2 & 10,9 & 12,6 & 8,8 & 8,5 & 9,2 & 11,3 \\
$(100-150]$ & 14,2 & 8,0 & 14,3 & 8,9 & 11,5 & 8,0 & 12,2 & 8,3 \\
$(150-200]$ & 10,4 & 3,3 & 10,1 & 4,6 & 8,2 & 3,7 & 8,1 & 3,2 \\
$(200-500]$ & 18,1 & 3,9 & 20,9 & 6,6 & 16,7 & 4,8 & 16,9 & 5,3 \\
$(500-1000]$ & 4,2 & 0,7 & 8,2 & 1,7 & 5,2 & 1,1 & 6,2 & 0,7 \\
$(1000-2000]$ & 1,3 & 0,1 & 3,2 & 0,6 & 1,8 & 0,2 & 2,9 & 0,3 \\
$(2000-4000]$ & 0,2 & 0,0 & 0,8 & 0,1 & 0,6 & 0,0 & 0,8 & 0,2 \\
$>4000$ & 0,0 & 0,0 & 0,1 & 0,0 & 0,1 & 0,0 & 0,2 & 0,0 \\
Média & 175,9 & 70,5 & 276,5 & 106,9 & 185,0 & 70,0 & 240,1 & 87,9 \\
\hline
\end{tabular}

Fonte: PNAD/LBGE, 1998 (microdados).

A última linha da Tabela 19 mostra que a renda média mensal per capita dos domicílios de jovens que não trabalham é superior à dos domicílios de jovens que trabalham. Para o grupo de jovens com idade entre 15 e 19 anos observa-se renda média mensal per capita das famílias onde os jovens não trabalham $57 \%$ e $51 \%$ maior do que nas famílias com jovens trabalhando, nas áreas urbana e rural, respectivamente. Entre os jovens de 20 a 24 anos de idade, a diferença de rendimentos entre as famílias com jovens trabalhando e não trabalhando é bem menor. A renda média mensal per capita das famílias com jovens que não trabalham é $30 \%$ e $25 \%$ maior do que nas famílias com jovens trabalhando, nas áreas urbana e rural, respectivamente. Observa-se, portanto, que a maior diferença de rendimentos encontra-se na zona urbana.

A principal parte da renda das famílias é, supostamente, auferida pelo seu chefe. A forma como o chefe se insere no mercado de trabalho é, portanto, uma variável 
importante para a análise da participação dos jovens na força de trabalho. A Tabela 20 mostra a porcentagem de jovens trabalhando, de acordo com o setor de ocupação do chefe de família. Os dados indicam que a inserção do chefe de família no setor primário resulta em maior proporção de jovens trabalhando. Tal resultado se dá devido ao caráter mais instável dos trabalhadores no setor primário, visto que estes são empregados nas atividades agropecuárias e extrativas (vegetais e minerais), bem como devido aos baixos níveis de remuneração vigentes neste setor, o que leva a uma maior necessidade dos jovens ingressarem no mercado de trabalho, com vistas a complementar a renda familiar. Outro ponto que deve ser considerado é a tendência de os filhos virem a trabalhar no mesmo setor de atividade de seus pais. De modo geral o setor primário exige pouca qualificação, o que leva a uma maior absorção dos jovens nestas atividades.

Tabela 20. Porcentagem de jovens trabalhando, de acordo com o setor de ocupação do chefe de família, estratificada por grupos de idade e pela situação do domicílio.

\begin{tabular}{lcccc}
\hline \multirow{2}{*}{$\begin{array}{l}\text { Setor de ocupação do } \\
\text { chefe de família }\end{array}$} & \multicolumn{2}{c}{ Jovens de 15 a 19 anos } & \multicolumn{2}{c}{ Jovens de 20 a 24 anos } \\
\cline { 2 - 5 } \multicolumn{1}{c}{ Urbano } & Rural & Urbano & Rural \\
\hline Primário & 52,1 & 70,1 & 67,5 & 78,8 \\
Secundário & 38,5 & 50,7 & 66,9 & 65,1 \\
terciário & 36,3 & 42,5 & 67,4 & 70,4 \\
\hline
\end{tabular}

Fonte: PNAD/IBGE, 1998 (microdados).

Da mesma forma, a Tabela 21 permite verificar que a porcentagem de jovens trabalhando, cujos chefes de família estão inseridos no mercado de trabalho informal, é significativamente superior que daqueles cujos chefes são empregadores ou possuem atividades no setor formal, sendo a diferença maior entre os setores formal e informal. Já foi verificado na seção 4.3 que os níveis de remuneração do mercado de trabalho informal é significativamente inferior ao do mercado de trabalho formal, sendo esta, portanto, uma das explicações para os jovens cujos chefes de família trabalham no mercado de trabalho informal estarem mais engajados no mercado de trabalho que os demais jovens. 
Tabela 21. Porcentagem de jovens trabalhando, de acordo com a inserção do chefe de família no mercado de trabalho, estratificada por grupos de idade e pela situação do domicílio.

\begin{tabular}{ccccc}
\hline Inserção do chefe de família & \multicolumn{2}{c}{ Jovens de 15 a 19 anos } & \multicolumn{2}{c}{ Jovens de 20 a 24 anos } \\
\cline { 2 - 5 } no mercado de trabalho & Urbano & Rural & Urbano & Rural \\
\hline Não trabalha & 29,9 & 39,8 & 49,9 & 48,8 \\
Setor formal & 32,3 & 44,6 & 65,7 & 64,8 \\
Setor informal & 43,5 & 67,9 & 68,8 & 78,3 \\
empregador & 39,9 & 58,5 & 67,0 & 73,5 \\
\hline
\end{tabular}

Fonte: PNAD/IBGE, 1998 (microdados).

Um resultado interessante é o fato de que o chefe de família não trabalhar leva a uma proporção relativamente baixa de jovens trabalhando, variando de 30\% (15 a 19 anos e idade) a 50\% (20 a 24 anos de idade) dos jovens. Procurando as causas desse fenômeno analisou-se estes indivíduos em separado, ou seja, os chefes de família que não tinham trabalho e tinham componentes jovens na família. Verificou-se que essa amostra era composta por 9.623 indivíduos, sendo $78 \%$ destes indivíduos inativos e os demais desempregados. Dentre os indivíduos inativos 50\% eram aposentados e/ou pensionistas. Estes resultados podem estar indicando que os beneficios dos chefes de família são suficientes para manter os jovens fora do mercado de trabalho ou que o incentivo para trabalhar dado aos jovens nessas famílias é menor que nas demais.

Corseuil et al. (2001) também verificaram que, no Brasil, Chile, Honduras e Peru os filhos de chefes desocupados trabalham menos do que os filhos de chefes ocupados.

Verificou-se assim que os filhos de pais inseridos no setor primário da economia e mercado de trabalho informal, possuem maior probabilidade de trabalharem que os demais jovens, o que deve-se ao caráter mais instável dessas ocupações e ao fato de que nestes setores, vigoram, em média, os mais baixos níveis de remuneração. Ademais, observou-se que à medida que a renda familiar se eleva as famílias evitam crescentemente utilizar seus membros mais jovens no mercado de trabalho. Desta forma, pode-se dizer que esta é uma indicação indireta de que, de fato, o trabalho precoce tem 
impactos negativos sobre o futuro dos jovens e que as famílias estão conscientes desta realidade, e, aquelas que podem, evitam que os jovens trabalhem. 


\subsection{Desemprego}

O desemprego é um dos mais graves problemas enfrentados pelos jovens no mercado de trabalho, principalmente para aqueles residentes na zona urbana, conforme mostrado na Figura 7.
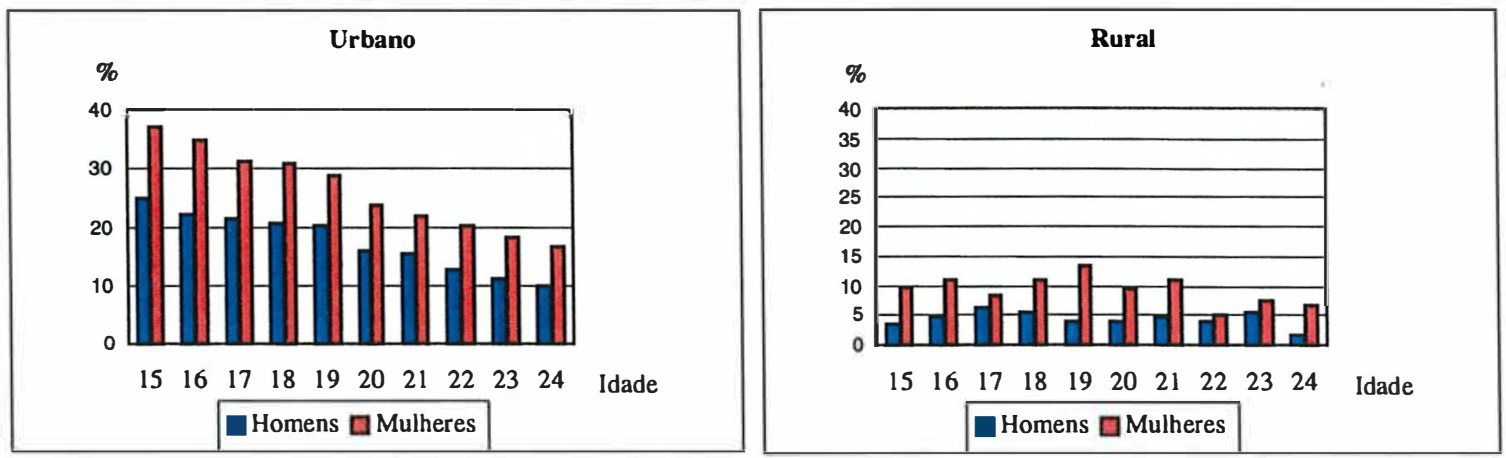

Figura 7 - Taxa de desemprego ${ }^{12}$ dos jovens estratificada por situação de domicílio, gênero e idade (Fonte: PNAD, 1998).

A taxa de desemprego é extremamente elevada para os jovens residentes na zona urbana, sendo esta de $10 \%$ a $37,3 \%$. Observa-se tendência decrescente da taxa de desemprego com a idade. A maior queda no desemprego ocorre na passagem dos 19 para os 20 anos de idade, onde a taxa de desemprego diminui em 4,4 pontos percentuais para os homens e 4,9 pontos percentuais para as mulheres. Ademais, observa-se que a taxa de desemprego feminina é cerca de 50\% superior à masculina.

Na zona rural a taxa de desemprego é significativamente inferior à taxa de desemprego urbana, varia de $1,7 \%$ a $13,4 \%$ e não apresenta comportamento monótono com a idade. A taxa de desemprego das mulheres é, em geral, mais que o dobro da taxa de desemprego dos homens.

A Tabela 22 descreve as taxas de desemprego da população brasileira em 1998, para jovens e adultos, estratificada por gênero, situação de domicílio (urbano e rural), regiões (Centro-Oeste, Nordeste, Norte, Sudeste e Sul), escolaridade (sem

12 A taxa de desemprego é a razão entre os desempregados e o total de indivíduos ocupados e desempregados. 
instrução e menos de um ano, 1 a 3 anos de estudo, 4 a 7 anos, 8 a 10 anos, 11 a 14 anos e 15 ou mais anos), cor (brancos, pardos e pretos) e posição no domicílio (chefe, cônjuge, filho e outro).

Tabela 22. Taxa de desemprego dos jovens e adultos, estratificada por gênero e por categorias (situação de domicílio, regiões, escolaridade, cor e posição no domicilio).

\begin{tabular}{lcccc}
\hline & \multicolumn{2}{c}{ Jovens de 15 a 24 anos } & \multicolumn{2}{c}{ Adultos de 25 a 64 anos } \\
\cline { 2 - 5 } & Homens & Mulheres & Homens & Mulheres \\
\hline Urbano & 16,8 & 25,2 & 5,8 & 9,3 \\
Rural & 4,4 & 9,4 & 1,4 & 2,7 \\
& & & & \\
Norte & 15,3 & 23,8 & 4,8 & 8,0 \\
Nordeste & 10,7 & 18,8 & 4,0 & 6,4 \\
Centro-Oeste & 13,3 & 20,6 & 3,9 & 8,3 \\
Sul & 11,6 & 19,4 & 3,9 & 6,6 \\
Sudeste & 16,9 & 25,7 & 5,8 & 9,5 \\
& & & & \\
Sem instrução e & & & & \\
menos de 1 ano & 7,4 & 16,1 & 3,7 & 4,9 \\
1 a 3 anos & 8,9 & 16,4 & 4,5 & 6,9 \\
4 a 7 anos & 15,1 & 22,8 & 5,6 & 8,7 \\
8 a 10 anos & 17,8 & 27,8 & 6,1 & 12,0 \\
11 a 14 anos & 12,6 & 19,6 & 4,8 & 8,7 \\
15 anos ou mais & 11,0 & 7,3 & 2,5 & 4,7 \\
& & & & \\
Brancos & 13,7 & 21,5 & 4,5 & 7,6 \\
Pardos & 13,3 & 22,5 & 5,1 & 8,4 \\
Pretos & 18,8 & 29,4 & 6,9 & 9,9 \\
& & & & \\
Chefe & 6,0 & 23,7 & 3,7 & 8,3 \\
Filho & 10,7 & 20,0 & 8,1 & 7,4 \\
Cônjuge & 16,0 & 23,8 & 10,9 & 11,4 \\
Outro & 13,8 & 18,0 & 9,6 & 8,3 \\
\hline Fonte: PNAD/BGE & & & &
\end{tabular}

Fonte: PNAD/IBGE, 1998 (microdados).

Observa-se que as taxas de desemprego são sempre mais elevadas para as mulheres do que para os homens (exceto para indivíduos classificados como filho e outro), e mais elevadas entre os jovens do que entre os adultos. Analisando cada categoria em separado, observa-se que a taxa de desemprego dos jovens é mais que o 
dobro da taxa de desemprego dos adultos em $88 \%$ dos casos, sendo três vezes a taxa de desemprego dos adultos em $25 \%$ dos casos. A taxa de desemprego das mulheres é, em muitos casos, o dobro da taxa de desemprego dos homens, sendo na maioria dos casos 60 a $80 \%$ maior que a dos homens.

O desemprego não se distribui de forma homogênea entre as regiões. As maiores taxas de desemprego encontram-se na região Sudeste, seguida da região Norte, para as duas faixas etárias. Sabe-se que as oportunidades de emprego prevalecentes são melhores na região Sudeste que nas demais regiões. Portanto, a maior disposição dos indivíduos residentes na região Sudeste para o trabalho e o maior incentivo à procura por trabalho poderia estar explicando as maiores taxas de desemprego desta região.

As maiores taxas de desemprego da região Norte em relação às três outras regiões (Centro-Oeste, Sul e Nordeste) deve-se principalmente à exclusão da área rural na pesquisa (PNAD). Conforme pode ser visto na Tabela 22 a taxa de desemprego na zona urbana é cerca de quatro e três vezes a taxa de desemprego da zona rural, para homens e mulheres, respectivamente.

A tabela 22 também mostra que a taxa de desemprego apresentou forma de "U" invertido em relação à escolaridade. A taxa de desemprego sobe até a categoria com educação de segundo grau incompleta (até 10 anos de estudo) e, a partir daí, declina. Observa-se, portanto, que um maior nível de escolaridade pode agravar a situação de desemprego ou minimizá-lo, o que depende do nível educacional que se esteja analisando. Pode-se então dizer que a educação elementar $\left(1^{\circ}\right.$ grau $)$ tende a elevar a exposição de um trabalhador ao desemprego, enquanto a educação secundária e, em particular, a educação superior, tende a reduzir a probabilidade de um trabalhador ficar desempregado. Resultado semelhante foi constatado por Barros et al. (1997), cujo estudo centrou-se na análise da estrutura do desemprego da região metropolitana de São Paulo, tendo como base de dados a PME (Pesquisa Mensal do Emprego) para o período de 1982 a 1993. 
A maior taxa de desemprego nos níveis medianos de escolaridade poderia ser explicada pela maior oferta de indivíduos com esse nível de escolaridade em relação aos níveis mais avançados. Por outro lado, a seletividade na busca por trabalho dos indivíduos com nível mediano de escolaridade, em relação aos grupos com menos escolaridade, seria maior, o que pode elevar a duração do desemprego para esse grupo de indivíduos. Os trabalhadores menos qualificados geralmente aceitam a primeira oferta de trabalho; já os indivíduos com um pouco de qualificação podem estar buscando melhores vagas, o que pode explicar o fato dos jovens com nível de escolaridade média apresentar taxa de desemprego mais elevada que os menos escolarizados.

A taxa de desemprego é mais elevada para os indivíduos não brancos em relação aos brancos (exceto para homens jovens, para os quais os brancos possuem taxa de desemprego ligeiramente superior à dos pardos), sendo a taxa de desemprego mais elevada para os pretos que para os pardos. Os diferenciais de taxa de desemprego entre brancos e pretos é significativamente mais elevada entre os jovens que entre os adultos. Entre os jovens a taxa de desemprego dos pretos é 40 e $30 \%$ mais elevada em relação à taxa de desemprego dos brancos, para homens e mulheres, respectivamente. Entre os adultos esses mesmos diferenciais alcançam 35 e $18 \%$. Tal fato pode demonstrar que o mercado passa a oferecer mais vagas para os negros adultos ou que estes, por necessidade, passam a aceitar qualquer trabalho que lhes seja oferecido (Tabela 22).

A taxa de desemprego mais alta para indivíduos não brancos reflete a desigualdade racial existente no Brasil. Por um lado existe a discriminação racial contra os indivíduos não brancos no mercado de trabalho. Por outro lado suas elevadas taxas de desemprego são resultado de um sistema de ensino mais acessível aos brancos, os quais são os mais escolarizados, o que facilita sua inserção no mercado de trabalho. Segundo Gois (2001) os negros, apesar de representarem 5,7\% da população brasileira, são apenas 2,2\% dos formandos de 18 cursos de nível superior avaliados pelo MEC no provão de 2000 . Quando se junta o número de negros e pardos esse grupo representa $45,2 \%$ da população e apenas $15,7 \%$ dos formandos. 
De acordo com Freeman e Holzer (1985) historicamente os jovens negros encontraram sérias dificuldades no mercado de trabalho americano, sendo que seus rendimentos são significativamente inferiores aos rendimentos dos brancos, bem como os retornos obtidos dos investimentos realizados em escolaridade. Entretanto, a pior constatação dos autores é relativa ao nível de emprego dos jovens negros, pois estes se deparam com taxas de desemprego bastante superiores àquelas encontradas pelos brancos. Em 1983, 45\% dos homens negros com idade entre 16 e 21 anos estavam empregados, contra $73 \%$ dos homens brancos.

Como pode ser visto na Tabela 22, a taxa de desemprego masculina é menor para os chefes de família, seguidos dos filhos, enquanto para as mulheres é menor entre as filhas, seguidas das chefes. O cônjuge possui salário reserva alto, visto que este tem maiores responsabilidades com os filhos e com os afazeres domésticos, exigindo, portanto, salário maior para aceitar uma oferta de trabalho, o que explica suas maiores taxas de desemprego. O grupo "outros" é de difícil interpretação, uma vez que inclui desde outros parentes e agregados até empregados domésticos.

Historicamente, no Brasil, os chefes de família são responsáveis pela maior parte do orçamento familiar. Portanto, o desemprego para esta categoria de trabalhadores tem conseqüências negativas não apenas para o indivíduo desempregado como também para sua família. Neste sentido, as baixas taxas de desemprego para os chefes de família, em relação aos demais indivíduos, pode se dar em razão da sua baixa seletividade na escolha de ofertas de trabalho, motivados por elevados custo de busca, ou seja, pelo custo de se manter desempregado e os prejuízos daí decorrentes para sua família.

Verificou-se assim que os jovens brasileiros enfrentam altas taxas de desemprego, as quais são significativamente mais elevadas nas áreas urbanas e para as mulheres. Verificou-se ainda que a situação de desemprego entre os jovens é mais grave na região Sudeste, para os jovens com nível mediano de escolaridade (4 a 10 anos de 
estudo), para jovens de cor preta e para os indivíduos cuja posição no domicílio é de cônjuge.

Em um país onde 50 milhões de pessoas vivem abaixo da linha de pobreza, o desemprego não pode ser considerado a principal causa da pobreza que assola o país. Entretanto isso não significa que o combate ao desemprego não seja relevante para a redução da pobreza, visto que nos últimos anos o desemprego vem afetando mais duramente os trabalhadores menos qualificados (com até quatro anos de estudo), os quais, de modo geral, se concentram nas camadas mais pobres da população. Segundo Rocha (2000), de julho de 1994 a maio de 1999, os trabalhadores menos qualificados perderam mais de 1,2 milhões de postos de trabalho. Manteve-se praticamente inalterado o número de postos ocupados por trabalhadores com quatro a oito anos de estudo e aumentou o número de postos para trabalhadores com mais de oito anos de escolaridade formal. Sendo assim, o combate ao desemprego deverá surtir mais efeito sobre as camadas mais pobres da população o que deve reduzir o grau de pobreza da população.

A crise de desemprego por que passa o Brasil é grave e complexa, sendo que não existe consenso entre os especialistas sobre suas causas. Independente disso há algumas questões quase que consensuais entre os especialistas sobre as quais deveriam ser tomadas algumas medidas corretivas. Trata-se do predomínio de baixas taxas de expansão da economia nas últimas duas décadas e a condução da economia a partir de 1990. Dentre os fatos econômicos relevantes da década de 90 , destacam-se a maior abertura da economia e a estabilização dos preços alcançada com a implementação do Plano Real em 1994. A abertura da economia rompeu com o modelo de desenvolvimento econômico via proteção da indústria nacional, o que provocou uma série de transformações na base produtiva nacional. O setor produtivo nacional foi obrigado a realizar investimentos maciços em modernização organizacional e tecnológica para alcançar produtividade e competitividade. Um dos mais perversos produtos desse processo foi a elevação da taxa de desemprego, principalmente no setor industrial. Esses dois pontos explicam, em grande parte, a grave crise de desemprego 
enfrentada pelo país nos últimos anos. É necessário, portanto, enfrentar os aspectos estruturais do problema. Além de ser uma tarefa muito difícil não é objetivo deste trabalho enumerar as políticas necessárias para equacionar este problema. Serão feitas apenas algumas considerações.

A principal causa da pobreza de grande parte da população brasileira é a alta concentração de renda que existe no país. O Brasil tem uma das piores distribuições de renda do mundo. Segundo Rocha (2000), em 1997 o 1\% mais rico da população detinha $13,7 \%$ da renda nacional, enquanto os $50 \%$ mais pobres se apropriavam de apenas $13 \%$ dos rendimentos. Devido à alta concentração de renda existe no país $34 \%$ da população abaixo da linha de pobreza, sendo este um importante fator que contribui para as altas taxas de desemprego observadas. Cada vez mais pobres entram em massa no mercado de trabalho em busca de complementação de renda familiar. Aposentados, jovens, crianças e pessoas que já tem um emprego procuram trabalho ou fazem horas extras em busca de aumento de renda. Segundo Pochmann (1999) o Brasil queima 13 milhões de empregos por causa da necessidade dos trabalhadores de complementar sua renda para sobreviver. Cerca de 3,2 milhões de brasileiros precisam ter duplo emprego para manter-se, outros 5,2 milhões de aposentados estão no mercado pela mesma razão, 2,8 milhões de menores de 14 anos que deveriam estar estudando, precisam ajudar a família e também saem em busca de ocupação, outras 26 milhões de pessoas trabalham acima da jornada legal de trabalho, cujas horas extras representariam 2,4 milhões de postos de trabalho. De modo geral são as famílias mais pobres que lançam suas crianças, jovens e aposentados no mercado de trabalho e cujos membros procuram mais de um emprego em busca da complementação da renda familiar. Desta forma pode-se dizer que o desemprego é um dos agravantes da pobreza e que a pobreza da população brasileira é, sob a ótica vista acima, uma das causas das elevadas taxas de desemprego observadas na década de 90 .

Políticas de combate à pobreza seria, no Brasil, também eficaz no combate ao desemprego, visto que tiraria do mercado aquelas pessoas que só estão trabalhando 
para complementar a renda familiar, que seriam principalmente jovens e crianças. São políticas que se centram no crescimento econômico e/ou no declínio do grau de desigualdade.

As duas últimas décadas do século 20 apresentaram estagnação da renda per capta o que, segundo Pochmann (2000), refletiu em aumento nas taxas de desemprego a partir da década de 90 visto que, a cada ano, 1,5 milhão de pessoas ingressam potencialmente no mercado de trabalho. Segundo o autor, para poder gerar o número de empregos necessários a economia do Brasil deveria estar crescendo a taxas superiores a 5\% ao ano. De acordo com Pochmann (2000) a situação de desemprego não encontrará forma de enfrentamento sem altas taxas de crescimento econômico, pois até 2010 estima-se que a população economicamente ativa continuará fortemente pressionando o mercado de trabalho.

Segundo Barros e Mendonça (1997), dado o elevado grau de desigualdade no Brasil, é possível reduzir dramaticamente a pobreza sem crescimento econômico, simplesmente fazendo com que o grau de desigualdade no Brasil seja próximo daquele observado para um país latino-americano típico. Segundo os autores se o grau de desigualdade do Brasil fosse reduzido ao da Venezuela, a pobreza no Brasil seria 18 pontos percentuais menor, declinando de $35 \%$ para $15 \%$. Tal declínio no grau de pobreza somente seria alcançado via crescimento econômico com uma década de crescimento contínuo de cerca de $7 \%$ ao ano.

Em relação aos jovens pode-se dizer que as altas taxas de desemprego por eles enfrentadas traz consequiências muito mais sérias do que a própria pobreza. Milhões de jovens brasileiros estão cercados por um ambiente desanimador, sem perspectivas de uma boa escolaridade e muito menos de um bom emprego e consequentemente de melhora de vida. A perpetuação do ciclo de pobreza, ou seja, a reprodução das condições sociais vigentes, onde os mais pobres têm menos escolaridade, trabalham mais e auferem os menores rendimentos é vista como certa. Essa visão é prejudicial à grande 
maioria de jovens, principalmente aos mais pobres e carentes de formação, levando-os muitas vezes à criminalidade e prostituição. Faz-se necessário que se crie no país uma política voltada especificamente para a juventude para amenizar os efeitos perversos da exclusão de uma grande parte de seus jovens das escolas e/ou do mercado de trabalho. 


\section{METODOLOGIA}

Algumas variáveis utilizadas em pesquisas sócio-econômicas não são observadas na forma contínua. Estas, geralmente, representam respostas qualitativas dos indivíduos. É difícil, por exemplo, observar a propensão de um indivíduo a escolher entre trabalhar e estudar. O que se observa empiricamente é a decisão de trabalhar e/ou estudar ou não realizar nenhuma dessas atividades. Nesse caso, a resposta do evento "escolha da forma de alocação do tempo" é qualitativa, onde existem várias alternativas e o indivíduo escolhe uma delas. Esse trabalho fará uso deste tipo de modelo em sua análise econométrica.

\subsection{Modelos de resposta qualitativa}

Esses modelos têm em comum o fato de que a variável dependente apresenta-se na forma discreta. Aplicações desses modelos na determinação da participação dos indivíduos na força de trabalho, para o Brasil, foram abordadas por Kassouf (1999, 1998), Fernandes e Picchetti (1999), Fernandes (1996), Silva (1997) e Tiefenthaler (1989).

Segundo MacFaden (1974), é possível deduzir de um modelo de escolha individual, propriedades do comportamento de escolha da população. Em seu trabalho, esse autor procura formular modelos econométricos do comportamento da escolha da população, a partir de distribuições de escolhas individuais.

Para esse autor, o estudo do comportamento da escolha deve ser composto por: 
1. Objetos de escolha e o conjunto de alternativas disponíveis aos tomadores de decisão;

2. Atributos observáveis dos tomadores de decisão;

3. Modelo de escolha e comportamento individual, e a distribuição das características da escolha na população.

\subsubsection{Equações de trabalho e freqüência à escola}

O modelo proposto para se investigar as formas de alocação de tempo dos jovens será o de estimar um modelo lógite multinomial para a probabilidade de o jovem só estudar, só trabalhar, estudar e cuidar de afazeres domésticos, trabalhar e estudar, só cuidar de afazeres domésticos ou não realizar nenhuma dessas atividades

Os modelos lógite multinomiais são aqueles em que a variável dependente assume mais de dois valores, sendo esses de natureza discreta. Assim, a variável dependente tomará o valor 0 se o indivíduo só estuda, 1 se o indivíduo só trabalha, 2 se o indivíduo estuda e cuida de afazeres domésticos, 3 se o indivíduo estuda e trabalha, 4 se o indivíduo só cuida de afazeres domésticos e 5 se o indivíduo não trabalha nem estuda.

Modelos deste tipo foram usados por Grootaert e Patrinos (1998) para analisar os determinantes da decisão de alocação do tempo das crianças, com idade entre 5 e 14 anos, entre o trabalho e a escola na Costa do Marfim (1988), Colômbia (1993), Bolívia (1993) e Filipinas (1992). Leme e Wajnman (2000) realizaram trabalho semelhante para os adolescentes brasileiros (10 a 19 anos de idade) usando dados de 1998. Kassouf (1999) estimou este modelo com as categorias estuda e/ou trabalha para crianças brasileiras de 7 a 14 anos de idade, com base na PNAD de 1995. Courseuil et al. (2001) investigaram os determinantes da alocação do tempo dos jovens de 12 a 17 anos em 4 países latino-americanos: Brasil, Chile, Honduras e Peru. Menezes-Filho et al. (2000) analisaram os determinantes da alocação do tempo dos jovens entre trabalho e estudo para 17 países da América Latina. 
A estrutura geral desses modelos é baseada na análise de probabilidades. Partindo-se de uma representação adotada por Greene (1997), pode-se ilustrar a idéia do modelo que será adotado da seguinte maneira:

$\operatorname{Prob}($ evento $j$ ocorrer $)=\operatorname{Prob}(Y=j)=F\left[\beta^{\prime} x\right]$

onde $j$ são as seis opções de que dispõe o jovem (só estudar, só trabalhar, estudar e cuidar de afazeres domésticos, trabalhar e estudar, só cuidar de afazeres domésticos e não realizar nenhuma dessas atividades), portanto, como dito acima, $j$ pode assumir os valores $0,1,2,3,4$ e 5 . O conjunto de parâmetros $\beta$ reflete o impacto das mudanças em $x$ (matriz de atributos observáveis para os indivíduos) na probabilidade de um determinado indivíduo escolher uma das seis opções.

A especificação do modelo lógite multinomial a ser usada é

$$
\mathrm{P}_{j}=\operatorname{Prob}\left(Y_{i}=j\right)=\frac{e^{\beta_{j}{ }^{\prime} x_{i}}}{\sum_{k=0}^{J} e^{\beta_{k}{ }^{\prime} x_{i}}}
$$

sendo: $Y_{i}=$ variável aleatória que indica a escolha feita,

$$
\begin{aligned}
& \mathrm{P}_{j}=\operatorname{Prob}\left(Y_{i}=j\right)=\text { probabilidade de um indivíduo } i \text { optar pela escolha } j, \\
& x=\text { matriz de atributos observáveis para os indivíduos, } \\
& \beta=\text { vetor de parâmetros a ser estimado. }
\end{aligned}
$$

A probabilidade de ocorrência de cada resposta, de acordo com este modelo, varia entre os indivíduos com diferentes características de idade, gênero e cor do jovem, escolaridade, idade e sexo do chefe de família, número de componentes na familia por faixa etária, região de residência e renda familiar per capita. O método de máxima verossimilhança é o mais indicado para a estimação desse tipo de modelo. 
Diferenciando a função de verossimilhança e usando o método de Newton será encontrado um conjunto de coeficientes que não são, entretanto, fáceis de interpretar, pois não representam diretamente as respostas marginais como no método dos Mínimos Quadrados Ordinários. Desta forma, serão calculados os efeitos marginais para facilitar a análise dos resultados. Para obter os efeitos marginais primeiramente pressupõe-se que $\beta_{0}=0$. As probabilidades são, então,

$$
\mathrm{P}_{j}=\operatorname{Prob}\left(Y_{i}=j\right)=\frac{e^{\beta_{j}{ }^{\prime} x_{i}}}{1+\sum_{k=1}^{J} e^{\beta_{k}{ }^{\prime} x_{i}}} \quad \quad \operatorname{para} j=1,2, \ldots, J
$$

e

$$
\mathrm{P}_{j}=\operatorname{Prob}\left(Y_{i}=0\right)=\frac{1}{1+\sum_{k=1}^{J} e^{\beta_{k} x_{i}}}
$$

Diferenciando as equações acima se encontram os efeitos marginais que são:

$$
\frac{\partial P_{j}}{\partial X_{i}}=P_{j}\left[\beta_{j}-\sum_{k=0}^{J} P_{k} \beta_{k}\right]=P_{j}\left[\beta_{j}-\bar{\beta}\right]
$$

Note que os sinais dos efeitos marginais podem ser diferentes dos sinais dos coeficientes estimados ${ }^{13}$.

\footnotetext{
${ }^{13}$ Para maiores detalhes sobre a interpretação dos efeitos marginais no modelo lógite multinomial, ver Greene (1997), cap. 19, pág. 914.
} 


\subsubsection{Equações de inatividade, emprego e desemprego}

$\mathrm{Na}$ estimação das equações inatividade, emprego e desemprego será usado o mesmo modelo proposto para análise das formas de alocação do tempo dos jovens. Será estimado um modelo lógite multinomial onde a variável dependente tomará o valor 0 se o indivíduo é inativo, 1 se o indivíduo é ativo e empregado e 2 se o indivíduo é ativo e desempregado. Fernandes e Picchetti (1999), utilizando dados da PNAD de 1995, utilizaram este modelo. A pesquisa buscava entender as características que afetam a probabilidade de um determinado indivíduo se encontrar desempregado em um determinado instante do tempo. Sua amostra restringiu-se a indivíduos com 10 anos ou mais de idade residentes em áreas metropolitanas.

O software a ser utilizado para estimar os modelos será o LIMDEP versão 7.0, desenvolvido por Greene (1995).

\subsection{Descrição das variáveis exógenas}

\subsubsection{Características dos jovens}

As características individuais incluídas são: experiência e escolaridade (variáveis essas representando o capital humano), idade, gênero e raça. A variável experiência foi construída a partir da idade do indivíduo e da idade em que começou a trabalhar, ou seja:

$\exp _{i}=$ idade $_{i}$ - idade em que o individuo $i$ começou a trabalhar

onde o índice $i$ refere-se a cada indivíduo.

Acredita-se que a experiência tem efeito positivo e importante na produtividade e, portanto, na inserção do jovem no mercado de trabalho e também nos seus rendimentos (o aumento da experiência aumenta o estoque de capital humano, o 
que deve aumentar o nível salarial). O aumento salarial, tudo mais constante, deverá aumentar a atratividade do mercado de trabalho para os jovens.

Na coleta de dados o IBGE considera como sendo anos de estudo apenas aqueles em que o indivíduo freqüentou escola e obteve aprovação em todas as disciplinas cursadas. Anos de estudo é uma variável proxy para educação.

Conforme mencionado por Fernandes e Picchetti (1999), as variáveis experiência e escolaridade são associadas à produtividade do trabalhador e, portanto, fornecem uma indicação da perda de renda monetária pela unidade familiar, caso o indivíduo não esteja empregado, o que pode afetar tanto a sua decisão de se inserir no mercado de trabalho como sua estratégia de busca por um emprego. Por outro lado, o grau de qualificação de um trabalhador pode, por aspectos relacionados à demanda por trabalho, afetar sua chance de conseguir emprego. A variável experiência, construída a partir da idade do indivíduo, pode influenciar a prioridade que o indivíduo dá ao trabalho em relação ao estudo, uma vez que os mais jovens conseguem auferir por mais tempo os benefícios associados aos seus investimentos em capital humano.

Serão construídas variáveis binárias para os grupos de cor existentes no Brasil, onde os indivíduos de cor branca e amarela foram agrupados, principalmente devido ao fato de o grupo de indivíduos de cor amarela ser pouco representativo numericamente (representando apenas $0,3 \%$ da amostra total). Estas variáveis serão incluídas para verificar se distintos grupos raciais apresentam diferentes formas de inserção no mercado de trabalho, o que pode ocorrer em virtude da existência de discriminação no mesmo.

\subsubsection{Características da família}

A inclusão da variável renda familiar líquida proveniente do trabalho dos indivíduos visa proporcionar uma medida do suporte financeiro que a família teria, caso o indivíduo em questão não estivesse empregado. Essa variável inclui a renda que o 
indivíduo possui proveniente de outras fontes que não seja o seu trabalho (aposentadoria e pensão, abono de permanência, aluguel, doação de não moradores do domicílio, juros, dividendos, etc.), mais a renda proveniente de todas as fontes auferidas pelos demais membros da família. Acredita-se que tal variável afete positivamente o salário reserva do indivíduo.

Postula-se que o tamanho da família afeta negativamente o salário reserva dos indivíduos, ou seja, quanto maior o número de elementos na família menor o salário reserva dos indivíduos. Entretanto, não apenas o tamanho da família pode ser importante, como também a distribuição etária dos seus membros. Desse modo, serão incluídas variáveis associadas ao número de indivíduos residentes no domicílio, sendo feita desagregação do número de indivíduos em dois grupos: indivíduos com 7 anos ou menos de idade e indivíduos com 8 ou mais anos de idade. A presença de muitas crianças na família deverá aumentar a participação dos jovens no mercado de trabalho, para ajudar no orçamento familiar. Por outro lado, a presença de indivíduos mais velhos deverá diminuir a participação do jovem no mercado de trabalho, visto que é maior a probabilidade de existir suporte financeiro por parte destes, levando os indivíduos mais jovens a permanecerem na escola. Portanto, acredita-se que há uma ordem cronológica na entrada dos membros da família, ocorrendo a entrada primeiro dos mais velhos para só então entrar os mais novos.

Serão incluídas variáveis binárias para a posição do indivíduo na família, pois, independentemente das demais características, a posição do indivíduo na família pode exercer influência nas motivações individuais de inserção no mercado de trabalho e nas estratégias de pesquisa por um emprego. A posição que o indivíduo ocupa na família pode afetar a preferência por um emprego que está além dos retornos pecuniários que este proporciona. 
Além das variáveis já listadas serão incluídas nas equações de trabalho e frequiência à escola as variáveis representando características do chefe de família, quais sejam, sua escolaridade, seu sexo e sua idade.

Acredita-se que quanto maior é a escolaridade dos responsáveis pelos jovens maior é a sua probabilidade de estudar e menor é sua probabilidade de somente trabalhar. $\mathrm{O}$ que se deve ao fato de que pais mais escolarizados possuem, geralmente, melhores salários, portanto, o aumento do grau de escolaridade do chefe de família deve diminuir a oferta de trabalho por parte de seus jovens. Por outro lado, uma família que possui como chefe de família uma pessoa com um bom nível de escolaridade, tradicionalmente, tende a incentivar seus jovens a estudar mais.

O gênero do chefe da família em que vive o jovem pode afetar suas decisões quanto à alocação de seu tempo entre trabalho e estudo, pois sabe-se que os homens auferem rendimentos substancialmente superiores aos das mulheres (ver, entre outros, Kassouf, 1998; Silva, 1997; Fernandes, 1996; Tiefenthaler, 1994). Portanto, chefe do sexo masculino pode indicar probabilidade menor do jovem ter que trabalhar visto que, no geral, o chefe homem possui mais condições de dar suporte financeiro a toda a família que a chefe mulher, além do fato de que as mulheres muitas vezes precisam cuidar dos filhos, ficando impossibilitadas de trabalhar. A idade do chefe, como o gênero, deve influir na forma de alocação do tempo do jovem no que diz respeito ao suporte financeiro dado aos jovens pelo chefe de sua família. Acredita-se que a idade do chefe afete negativamente a inserção dos jovens no mercado de trabalho.

\subsubsection{Proxy para fator demanda}

Como proxy para o fator demanda por trabalho serão incluídas variáveis binárias para as regiões brasileiras (Sudeste, Sul, Centro-Oeste, Norte e Nordeste). Trata-se de uma proxy fraca como fator demanda por trabalho, entretanto esta variável será testada como tal. Variáveis de região de residência podem captar diferenças sócioeconômicas entre as regiões, as quais podem afetar tanto a disposição individual de 
participar do mercado de trabalho como as oportunidades de emprego prevalecentes. Esta variável também pode refletir a atratividade do mercado de trabalho, a qual deve aumentar em regiões mais ricas e desenvolvidas. Nas regiões onde os salários ofertados são maiores e as chances de se obter emprego com carteira de trabalho assinada são mais elevadas, as taxas de participação do jovem no mercado de trabalho deverão ser mais elevadas.

A média, desvios padrões e a descrição das variáveis para 26.436 homens e 27.576 mulheres das áreas urbanas e 5.922 homens e 5.266 mulheres das áreas rurais, utilizadas para estimar as equações de trabalho e freqüiencia à escola e as equações de inatividade, emprego e desemprego são apresentadas nas Tabelas 23 e 24, respectivamente. 


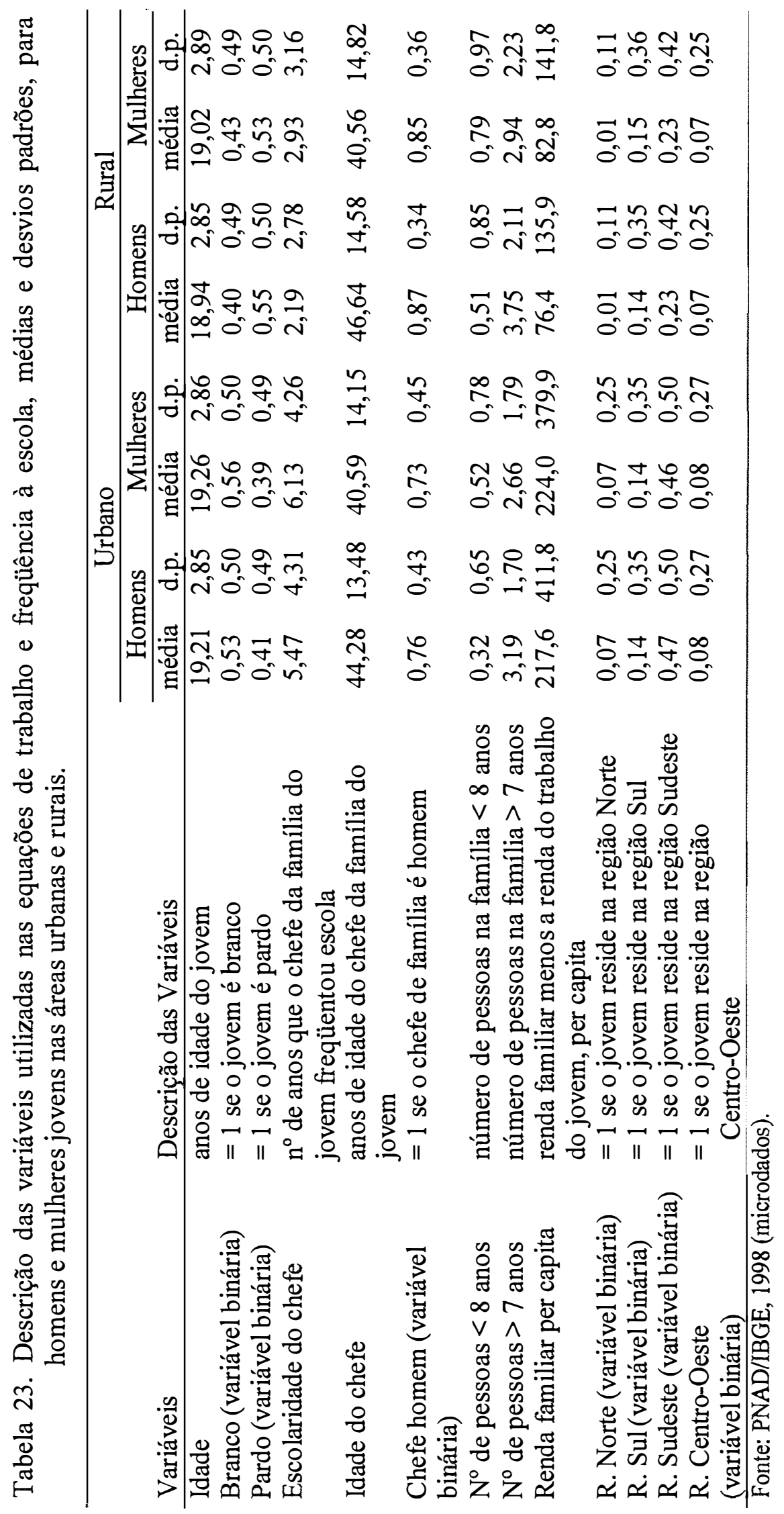




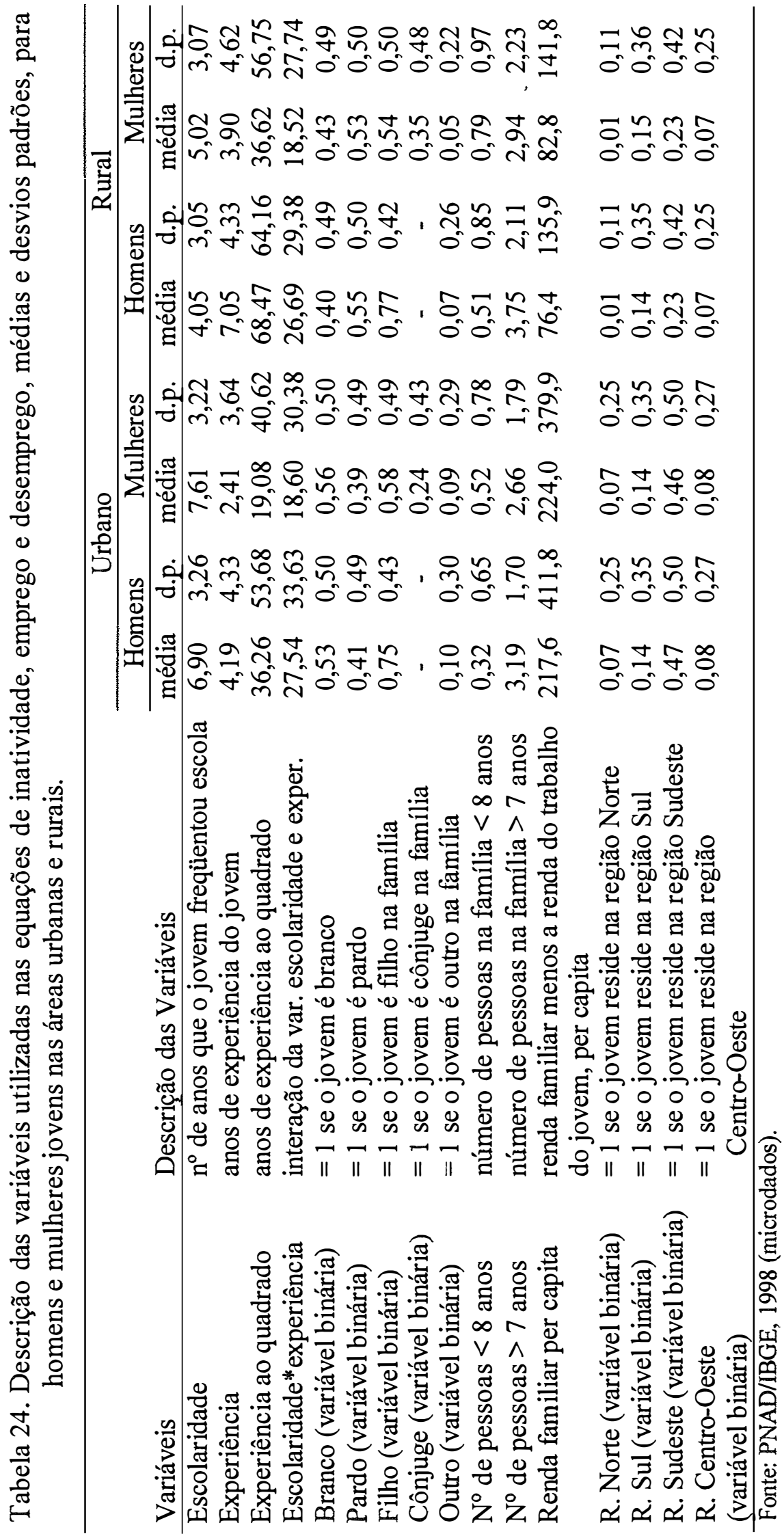




\section{RESULTADOS DOS MODELOS ECONOMÉTRICOS}

Neste capítulo são apresentados os resultados dos modelos econométricos para as equações de trabalho e frequiência à escola na primeira seção e, na segunda, as equações de inatividade, emprego e desemprego. O modelo usado é o lógite multinomial estimado por máxima verossimilhança e ponderado pelo fator de expansão da amostra.

\subsection{Equações de trabalho e frequiência à escola}

A Tabela 25 mostra a porcentagem de jovens na amostra em cada uma das alternativas estabelecidas. Observe que a maioria dos homens trabalha, independentemente de estudarem ou não, representando $60,1 \%$ e $83,3 \%$ do total, na zona urbana e rural, respectivamente. A maior parte das mulheres jovens cuida de afazeres domésticos, combinando esta atividade com estudo ou não, somando 50,9\% do total de jovens na área rural e 55,6\% na urbana. Uma pequena porcentagem de jovens só estuda, sendo que a maior porcentagem para essa categoria para os homens urbanos $(14,3 \%)$ e a menor para as mulheres das áreas rurais $(1,5 \%)$. Tal fato ocorre visto que uma grande porcentagem de mulheres jovens concilia o trabalho doméstico com o estudo.

Tabela 25. porcentagem de jovens de 15 a 24 anos em seis categorias mutuamente exclusivas.

\begin{tabular}{lcccc}
\hline & \multicolumn{2}{c}{ Urbano } & \multicolumn{2}{c}{ Rural } \\
\cline { 2 - 5 } & Homens & Mulheres & Homens & Mulheres \\
\hline Só estuda & 14,3 & 4,8 & 4,7 & 1,5 \\
Só trabalha & 39,2 & 22,9 & 55,6 & 31,1 \\
Só afaz. Dom. & 6,1 & 26,4 & 2,8 & 28,8 \\
Estuda e trabalha & 20,9 & 14,8 & 27,7 & 15,0 \\
Estuda e afaz. Dom. & 13,3 & 29,2 & 5,7 & 22,1 \\
Não estuda nem & 6,3 & 1,8 & 3,6 & 1,5 \\
trabalha & & & & \\
\hline
\end{tabular}

Fonte: PNAD/MGE, 1998 (microdados). 


\subsubsection{Equações de trabalho e freqüência à escola para jovens das áreas urbanas}

Os resultados do modelo lógite multinomial para homens e mulheres das áreas urbanas, encontram-se, respectivamente, nas Tabelas 26 e 27. Nelas estão apresentados os efeitos marginais e os testes-t entre parênteses.

Tabela 26. Equações de trabalho e freqüência à escola para homens jovens, com residência urbana.

\begin{tabular}{|c|c|c|c|c|c|c|}
\hline Variáveis & $\begin{array}{l}\text { Só estuda } \\
\text { (referência) }\end{array}$ & Só trabalha & $\begin{array}{l}\text { Estuda e cuida } \\
\text { de afazeres } \\
\text { domésticos }\end{array}$ & $\begin{array}{l}\text { Estuda e } \\
\text { Trabalha }\end{array}$ & $\begin{array}{l}\text { Só cuida de } \\
\text { afazeres } \\
\text { domésticos }\end{array}$ & $\begin{array}{c}\text { Não estuda } \\
\text { nem trabalha }\end{array}$ \\
\hline Constante & 0,492 & $\begin{array}{c}-1,180 \\
(-33,07)^{* * *}\end{array}$ & $\begin{array}{c}0,605 \\
(3,34)^{* * *}\end{array}$ & $\begin{array}{c}0,425 \\
(-14,59)^{* * *}\end{array}$ & $\begin{array}{c}-0,151 \\
(-21,88)^{* * *}\end{array}$ & $\begin{array}{c}-0,192 \\
(-23,97)^{* * *}\end{array}$ \\
\hline Idade & $-0,0397$ & $\begin{array}{c}0,0969 \\
(61,28)^{* * *}\end{array}$ & $\begin{array}{c}-0,0415 \\
(0,04)\end{array}$ & $\begin{array}{c}-0,0278 \\
(29,66)^{* * *}\end{array}$ & $\begin{array}{l}0,00635 \\
(36,61)^{* * *}\end{array}$ & $\begin{array}{c}0,00579 \\
(36,43)\end{array}$ \\
\hline Branco & $-0,00145$ & $\begin{array}{l}0,0256 \\
(0,80)\end{array}$ & $\begin{array}{c}-0,0164 \\
(-1,33)\end{array}$ & $\begin{array}{c}0,0372 \\
(1,51)\end{array}$ & $\begin{array}{l}-0,0273 \\
(-2,74)^{* *}\end{array}$ & $\begin{array}{l}-0,0176 \\
(-1,80)^{*}\end{array}$ \\
\hline Pardo & $-0,00307$ & $\begin{array}{c}0,0243 \\
(0,92)\end{array}$ & $\begin{array}{c}0,00363 \\
(0,61)\end{array}$ & $\begin{array}{c}0,00912 \\
(0,64)\end{array}$ & $\begin{array}{c}-0,00746 \\
(-0,54)\end{array}$ & $\begin{array}{l}-0,0266 \\
(-2,61)^{* *}\end{array}$ \\
\hline $\begin{array}{l}\text { Escolaridade do } \\
\text { chefe }\end{array}$ & 0,0128 & $\begin{array}{c}-0,0241 \\
(-29,69)^{* * *}\end{array}$ & $\begin{array}{c}0,0110 \\
(-3,87)^{* * *}\end{array}$ & $\begin{array}{c}0,00521 \\
(-19,06)^{* * *}\end{array}$ & $\begin{array}{l}-0,00262 \\
(-17,47)^{* * *}\end{array}$ & $\begin{array}{c}-0,00238 \\
(-17,45)^{* * *}\end{array}$ \\
\hline Idade do chefe & 0,00239 & $\begin{array}{c}-0,00661 \\
(-18,69)^{* * *}\end{array}$ & $\begin{array}{c}0,00178 \\
(-2,96)^{* * *}\end{array}$ & $\begin{array}{l}0,00126 \\
(-9,08)^{* * *}\end{array}$ & $\begin{array}{l}0,000284 \\
(-7,09)^{* *}\end{array}$ & $\begin{array}{l}0,000897 \\
(-4,31)^{* * *}\end{array}$ \\
\hline Chefe homem & 0,00345 & $\begin{array}{c}0,00147 \\
(0,04)\end{array}$ & $\begin{array}{c}-0,00361 \\
(-1,23)\end{array}$ & $\begin{array}{c}0,0220 \\
(0,87)\end{array}$ & $\begin{array}{l}-0,0205 \\
(-4,32)^{* *}\end{array}$ & $\begin{array}{l}-0,0161 \\
(-3,48)^{* * *}\end{array}$ \\
\hline $\begin{array}{l}N^{\circ} \text { de pessoas na } \\
\text { família }<8 \text { anos }\end{array}$ & $-0,00177$ & $\begin{array}{c}0,0559 \\
(7,83)^{* * *}\end{array}$ & $\begin{array}{c}-0,0185 \\
(0,02)\end{array}$ & $\begin{array}{c}-0,0348 \\
(1,21)\end{array}$ & $\begin{array}{l}0,00550 \\
(4,72)^{* * *}\end{array}$ & $\begin{array}{l}0,00952 \\
(5,85)^{* * *}\end{array}$ \\
\hline $\begin{array}{l}N^{\circ} \text { de pessoas na } \\
\text { família }>7 \text { anos }\end{array}$ & 0,00815 & $\begin{array}{l}-0,0192 \\
(-8,62)^{* * *}\end{array}$ & $\begin{array}{l}-0,000137 \\
(-5,09)\end{array}$ & $\begin{array}{c}0,0105 \\
(-2,92)^{* *}\end{array}$ & $\begin{array}{l}-0,00485 \\
(-7,10)\end{array}$ & $\begin{array}{c}0,00554 \\
(-0,48)\end{array}$ \\
\hline Renda per capita & 0,0000778 & $\begin{array}{l}-0,000214 \\
(-14,92)\end{array}$ & $\begin{array}{l}0,0000575 \\
(-3,94)^{* * *}\end{array}$ & $\begin{array}{l}0,000149 \\
(-4,42)^{* * *}\end{array}$ & $\begin{array}{l}-0,0000426 \\
(-8,11)^{* * *}\end{array}$ & $\begin{array}{l}-0,0000271 \\
(-7,66)^{* * *}\end{array}$ \\
\hline Região Norte & $-0,0189$ & $\begin{array}{c}0,000181 \\
(1,93)^{*}\end{array}$ & $\begin{array}{c}0,0202 \\
(3,92)^{* * *}\end{array}$ & $\begin{array}{l}0,00570 \\
(2,20)^{* *}\end{array}$ & $\begin{array}{c}0,0239 \\
(3,92)^{* * *}\end{array}$ & $\begin{array}{c}-0,0309 \\
(-1,53)\end{array}$ \\
\hline Região Sul & $-0,0776$ & $\begin{array}{c}0,140 \\
(13,45)^{* * *}\end{array}$ & $\begin{array}{l}-0,0197 \\
(6,82)^{* * *}\end{array}$ & $\begin{array}{l}-0,0347 \\
(7,93)^{* * *}\end{array}$ & $\begin{array}{c}0,0325 \\
(10,78)\end{array}$ & $\begin{array}{l}-0,0407 \\
(2,02)^{* *}\end{array}$ \\
\hline Região Sudeste & $-0,0200$ & $\begin{array}{c}0,0668 \\
(6,35)^{* * *}\end{array}$ & $\begin{array}{c}-0,0282 \\
(-1,15)\end{array}$ & $\begin{array}{c}-0,0309 \\
(1,56)\end{array}$ & $\begin{array}{c}0,0152 \\
(4,93)^{* * *}\end{array}$ & $\begin{array}{c}-0,00293 \\
(2,12)^{*}\end{array}$ \\
\hline $\begin{array}{l}\text { Região Centro- } \\
\text { Oeste }\end{array}$ & $-0,0604$ & $\begin{array}{c}0,0715 \\
(7,90)^{* * *}\end{array}$ & $\begin{array}{l}-0,0166 \\
(4,39)^{* * *}\end{array}$ & $\begin{array}{l}-0,00384 \\
(6,16)^{* * *}\end{array}$ & $\begin{array}{c}0,0192 \\
(6,55)^{* * *}\end{array}$ & $\begin{array}{l}-0,00984 \\
(3,61)^{* * *}\end{array}$ \\
\hline $\begin{array}{l}\text { Observações } \\
\text { Teste mult. } \\
\text { Lagrange }\end{array}$ & $\begin{array}{c}26.436 \\
13.200,24^{* * *}\end{array}$ & & & & & \\
\hline
\end{tabular}


Tabela 27. Equações de trabalho e freqüência à escola para mulheres jovens, com residência urbana.

\begin{tabular}{|c|c|c|c|c|c|c|}
\hline Variáveis & $\begin{array}{l}\text { Só estuda } \\
\text { (referência) }\end{array}$ & Só trabalha & $\begin{array}{c}\text { Estuda e cuida } \\
\text { de afazeres } \\
\text { domésticos }\end{array}$ & $\begin{array}{l}\text { Estuda e } \\
\text { Trabalha }\end{array}$ & $\begin{array}{l}\text { Só cuida de } \\
\text { afazeres } \\
\text { domésticos }\end{array}$ & $\begin{array}{l}\text { Não estuda } \\
\text { nem trabalha }\end{array}$ \\
\hline Constante & 0,0625 & $\begin{array}{c}-1,110 \\
(-19,63)^{* * *}\end{array}$ & $\begin{array}{c}1,376 \\
(8,05)^{* * *}\end{array}$ & $\begin{array}{c}-0,0754 \\
(-8,16)^{* * *}\end{array}$ & $\begin{array}{c}-0,165 \\
(-8,73)^{* * *}\end{array}$ & $\begin{array}{c}-0,0895 \\
(-11,50)^{* * *}\end{array}$ \\
\hline Idade & $-0,00951$ & $\begin{array}{c}0,0659 \\
(41,97)^{* * *}\end{array}$ & $\begin{array}{l}-0,0840 \\
(4,30)^{* * *}\end{array}$ & $\begin{array}{l}-0,00696 \\
(22,53)^{* * *}\end{array}$ & $\begin{array}{c}0,0329 \\
(32,56)^{* * *}\end{array}$ & $\begin{array}{l}0,00180 \\
(20,43)^{* * *}\end{array}$ \\
\hline Branco & 0,00980 & $\begin{array}{l}-0,00991 \\
(-2,53)^{* *}\end{array}$ & $\begin{array}{l}-0,0194 \\
(-2,88)^{* * *}\end{array}$ & $\begin{array}{l}0,0358 \\
(-1,14)\end{array}$ & $\begin{array}{l}-0,0216 \\
(-2,76)^{* * *}\end{array}$ & $\begin{array}{c}0,00542 \\
(-0,63)\end{array}$ \\
\hline Pardo & $-0,0000655$ & $\begin{array}{c}0,00382 \\
(0,10)\end{array}$ & $\begin{array}{c}-0,0208 \\
(-0,45)\end{array}$ & $\begin{array}{c}0,0168 \\
(0,52)\end{array}$ & $\begin{array}{c}-0,00463 \\
(-0,08)\end{array}$ & $\begin{array}{c}0,00493 \\
(0,79)\end{array}$ \\
\hline $\begin{array}{l}\text { Escolaridade do } \\
\text { chefe }\end{array}$ & 0,00382 & $\begin{array}{l}-0,00516 \\
(-20,11)^{* * *}\end{array}$ & $\begin{array}{c}0,0160 \\
(-12,17)^{* * *}\end{array}$ & $\begin{array}{c}0,00770 \\
(-13,27)^{* * *}\end{array}$ & $\begin{array}{c}-0,0208 \\
(-26,23)^{* * *}\end{array}$ & $\begin{array}{l}-0,00155 \\
(-14,50)^{* * *}\end{array}$ \\
\hline Idade do chefe & 0,000802 & $\begin{array}{l}-0,00212 \\
(-12,52)^{* * *}\end{array}$ & $\begin{array}{c}0,00508 \\
(-4,25)^{* * *}\end{array}$ & $\begin{array}{l}0,00228 \\
(-6,09)^{* * *}\end{array}$ & $\begin{array}{l}-0,00617 \\
(-16,68)^{* * *}\end{array}$ & $\begin{array}{l}0,000129 \\
(-5,40)^{* * *}\end{array}$ \\
\hline Chefe homem & $-0,00350$ & $\begin{array}{c}-0,0332 \\
(0,03)\end{array}$ & $\begin{array}{c}-0,0161 \\
(1,05)\end{array}$ & $\begin{array}{l}-0,0612 \\
(-2,41)^{* *}\end{array}$ & $\begin{array}{c}0,117 \\
(7,01)^{* * *}\end{array}$ & $\begin{array}{c}-0,00309 \\
(0,07)\end{array}$ \\
\hline $\begin{array}{l}\mathrm{N}^{\circ} \text { de pessoas na } \\
\text { familia }<8 \text { anos }\end{array}$ & $-0,00613$ & $\begin{array}{l}-0,00786 \\
(3,19)^{* *}\end{array}$ & $\begin{array}{c}-0,0430 \\
(1,28)\end{array}$ & $\begin{array}{c}-0,0416 \\
(0,28)\end{array}$ & $\begin{array}{c}0,0903 \\
(8,82)^{* *}\end{array}$ & $\begin{array}{l}0,00839 \\
(7,15)^{* * *}\end{array}$ \\
\hline $\begin{array}{l}N^{\circ} \text { de pessoas na } \\
\text { família }>7 \text { anos }\end{array}$ & 0,00369 & $\begin{array}{l}-0,00107 \\
(-6,35)^{* *}\end{array}$ & $\begin{array}{c}0,0212 \\
(-3,06)^{* * *}\end{array}$ & $\begin{array}{l}0,0250 \\
(-0,48)\end{array}$ & $\begin{array}{c}-0,0484 \\
(-13,34)^{* * *}\end{array}$ & $\begin{array}{l}-0,000440 \\
(-4,45)^{* * *}\end{array}$ \\
\hline Renda per capita & 0,0000241 & $\begin{array}{l}-0,000129 \\
(-15,75)^{* * *}\end{array}$ & $\begin{array}{l}0,000113 \\
(-9,52)^{* * *}\end{array}$ & $\begin{array}{l}0,0000241 \\
(-11,25)^{* * *}\end{array}$ & $\begin{array}{l}-0,0000470 \\
(-11,83)^{* * *}\end{array}$ & $\begin{array}{c}0,0000147 \\
(-2,52)^{* *}\end{array}$ \\
\hline Região Norte & 0,00296 & $\begin{array}{c}-0,0197 \\
(-1,29)\end{array}$ & $\begin{array}{c}0,0424 \\
(0,30)\end{array}$ & $\begin{array}{l}0,0185 \\
(-0,12)\end{array}$ & $\begin{array}{c}-0,0359 \\
(-1,66)\end{array}$ & $\begin{array}{c}-0,00829 \\
(-1,86)^{*}\end{array}$ \\
\hline Região Sul & $-0,0175$ & $\begin{array}{c}0,0869 \\
(8,20)^{* * *}\end{array}$ & $\begin{array}{l}-0,0667 \\
(3,73)^{* * *}\end{array}$ & $\begin{array}{c}0,0318 \\
(6,85)^{* * *}\end{array}$ & $\begin{array}{l}-0,0222 \\
(4,81)^{* * *}\end{array}$ & $\begin{array}{c}-0,0122 \\
(0,87)\end{array}$ \\
\hline Região Sudeste & $-0,00205$ & $\begin{array}{c}0,0712 \\
(4,26)^{* * *}\end{array}$ & $\begin{array}{l}-0,0610 \\
(-1,85)^{*}\end{array}$ & $\begin{array}{c}-0,00484 \\
(0,64)\end{array}$ & $\begin{array}{c}-0,00414 \\
(0,76)\end{array}$ & $\begin{array}{c}0,000863 \\
(0,87)\end{array}$ \\
\hline $\begin{array}{l}\text { Região Centro- } \\
\text { Oeste }\end{array}$ & $-0,00730$ & $\begin{array}{c}0,0466 \\
(3,29)^{* * *}\end{array}$ & $\begin{array}{c}-0,0420 \\
(0,98)\end{array}$ & $\begin{array}{c}0,0452 \\
(3,72)^{* * *}\end{array}$ & $\begin{array}{c}-0,0402 \\
(0,98)\end{array}$ & $\begin{array}{c}-0,00227 \\
(0,86)\end{array}$ \\
\hline $\begin{array}{l}\text { Observações } \\
\text { Teste mult. } \\
\text { Lagrange }\end{array}$ & $\begin{array}{c}27.576 \\
15.506,31^{* * *}\end{array}$ & & & & & \\
\hline
\end{tabular}


O vetor de variáveis exógenas incluídas nesta análise, para estimar a equação de trabalho e freqüência à escola é: idade, variáveis binárias para grupos de cor (branca, parda e preta - variável omitida), escolaridade e idade do chefe de família, variável binária representando o sexo do chefe (chefe homem, chefe mulher - variável omitida), número de membros na família com 7 ou menos anos de idade, número de membros na família com mais 8 ou mais anos de idade, renda familiar per capita e variáveis binárias para a região de residência do jovem (Região Norte, Região Sul, Região Sudeste, Região Centro-Oeste e Região Nordeste - variável omitida).

No modelo lógite multinomial a análise do impacto de cada variável explanatória na probabilidade de o jovem só trabalhar, estudar e cuidar de afazeres domésticos, combinar trabalho e escola, só cuidar de afazeres domésticos e não realizar nenhuma dessas atividades é feita relativamente ao impacto na probabilidade que o jovem possui de só estudar (categoria de referência).

Os resultados obtidos indicam que quanto mais velho o jovem, maior é a probabilidade de ele apenas trabalhar, só cuidar de afazeres domésticos ou não fazer nenhuma atividade, sendo que o maior efeito é na probabilidade de só trabalhar. Por outro lado, observa-se que quanto mais avançada é a idade do jovem menor é a probabilidade de ele estudar, independente de estar trabalhando ou não. Ademais, observa-se que o efeito negativo da idade sobre a probabilidade de estudar e cuidar de afazeres domésticos é significativo apenas para as mulheres.

Leme e Wajnman (2000), a partir de dados da PNAD de 1981 a 1998, estimaram um modelo de alocação de tempo para jovens de 10 a 19 anos de idade. As autoras optaram por não dividir a amostra entre homens e mulheres e indivíduos residentes na zona rural e urbana. Trabalharam com variáveis binárias para identificar o sexo do indivíduo e representar a área de residência do indivíduo. As autoras trabalharam com quatro formas de alocação de tempo: a) só estudar, b) só trabalhar, c) estudar e trabalhar e d) não estudar nem trabalhar. Verificaram que a idade diminui fortemente a probabilidade de só estudar e aumenta a probabilidade de só trabalhar. 
De acordo com Jensen e Nielsen (1997) desde que a idade é associada com mais experiência e mais capital humano, crianças e jovens com mais idade deverá ter, potencialmente, maiores salários que aqueles de menos idade, aumentando assim, sua participação no mercado de trabalho.

Barros e Mendonça (1991) analisaram a frequência à escola e a participação no mercado de trabalho de jovens em três áreas metropolitanas do Brasil, usando dados de 1987. Somente as variáveis representando a renda, região, gênero e idade foram incluídas no modelo. Eles também observaram que a idade tem efeito muito forte em aumentar a probabilidade de os jovens trabalharem e diminuir a probabilidade de freqüentarem a escola.

Os resultados obtidos para as variáveis binárias representando a cor dos jovens indicaram que a mulher jovem ser de cor branca aumenta sua probabilidade de só estudar e diminui a probabilidade das demais alternativas em relação às jovens de cor preta. Tais resultados podem estar indicando que as jovens da raça negra não possuem $o$ mesmo grau de acessibilidade no sistema de ensino formal. As causas de tal fenômeno devem estar nas condições sócio-econômicas deste segmento populacional, o qual possui rendimento médio inferior à população branca, o que por sua vez, se dá em grande parte devido à pior qualificação da população negra [ver, entre outros, Silva (1997)]. Percebese, portanto, o ciclo vicioso que existe para este segmento populacional na sua formação e inserção no mercado de trabalho.

A escolaridade do chefe de familia contribui para aumentar a probabilidade de o jovem estudar, independente de ele estar trabalhando ou não. Por outro lado a escolaridade do chefe diminui a probabilidade de o jovem só trabalhar, só cuidar de afazeres domésticos e não ter nenhuma atividade.

Leme e Wajnman (2000) e Courseil et al. (2001) verificaram que a escolaridade dos pais tem forte relação positiva com só estudar e negativa com as demais formas de alocação do tempo. 
Menezes-Filho et al. (2000), analisando 17 países da América Latina, verificaram que a probabilidade de os jovens de 16 e 17 anos, somente estudar varia de $30 \%$ para aqueles que têm pais analfabetos para cerca de $85 \%$ para jovens cujos pais possuem nível universitário.

A maioria dos coeficientes para a variável representando o sexo do chefe de família não foi estatisticamente significativo, exceto o efeito negativo na probabilidade de os homens jovens só realizarem atividades domésticas e efeito positivo para as mulheres jovens. Além do mais, diminui a probabilidade de os homens não realizarem nenhuma atividade e das mulheres não estudar e trabalhar.

A idade do chefe da família é um importante fator explicativo das decisões de alocação de tempo dos jovens. Na equação dos homens a idade do chefe diminui a probabilidade de o jovem só trabalhar e aumenta a probabilidade das demais alternativas. Já na equação das mulheres a idade do chefe de família diminui a probabilidade de as jovens só trabalharem e de apenas realizarem atividades domésticas e aumenta a probabilidade das demais alternativas.

Na equação dos homens (Tabela 26) o aumento de pessoas na família com sete anos ou menos de idade causou um aumento estatisticamente significativo nas probabilidades de só trabalhar, só cuidar de afazeres domésticos e não estudar nem trabalhar e diminuiu a probabilidade de os jovens estudarem, independente de exercerem outra atividade ou não. $\mathrm{O}$ aumento na probabilidade de os jovens só trabalharem deve-se à necessidade de busca de mais renda para suprir as necessidades dos membros mais jovens da familia, enquanto o aumento na probabilidade de só cuidar de afazeres domésticos deve-se dar em razão de os jovens substituírem seus pais nos cuidados com as crianças, liberando-os para o trabalho. $\mathrm{Na}$ equação das mulheres (Tabela 27) o aumento de crianças na família diminui a probabilidade de as jovens só trabalharem e aumenta sua probabilidade de só cuidar de afazeres domésticos, mostrando que as mulheres jovens ajudam ou substituem seus pais no cuidado com as crianças. 
O número de componentes na família com oito ou mais anos de idade aumenta a probabilidade de as mulheres jovens só estudar e estudar e cuidar de afazeres domésticos e diminui a probabilidade das demais alternativas. Para os homens jovens essa variável afeta positivamente a probabilidade de só estudar e estudar e trabalhar e negativamente as demais alternativas. A existência de um maior número de membros mais velhos na família deve substituir aqueles mais jovens no mercado de trabalho, possibilitando a estes o acesso ao estudo.

Um estudo realizado nas Filipinas mostrou que a probabilidade de participação das crianças no mercado de trabalho decresce na presença de irmãos mais velhos, indicando substituição das crianças no mercado de trabalho pelos membros mais velhos da família [De Graff et al. citado por Grootaert e Kanbur (1995)].

Menezes-Filho et al. (2000) verificou que a probabilidade de os jovens de 16 e 17 anos somente estudar diminui de $60 \%$ para $20 \%$ quando o número de irmãos mais novos aumenta de 1 para 9. Para o grupo de jovens com 12 e 13 anos a probabilidade cai de $85 \%$ para $70 \%$.

A renda familiar per capita foi altamente significativa em aumentar a probabilidade de o jovem estudar, independentemente se ele combina o estudo com outra atividade ou não, e de diminuir a probabilidade de somente trabalhar, de somente cuidar de afazeres domésticos. Tal resultado era esperado, visto que, entre os pesquisadores da área, é consenso que a taxa de escolarização é crescente com o nível de renda familiar per capita. Portanto, os resultados obtidos confirmam a relação direta entre o nível de rendimento familiar per capita e escolaridade.

Leme e Wajnman (2000) verificaram que a renda familiar afeta positivamente a probabilidade de o jovem estudar (principalmente sem trabalhar) e negativamente a de trabalhar sem estudar e também de não ter nenhuma atividade. 


\subsubsection{Equações de trabalho e freqüência à escola para jovens das áreas rurais}

Os resultados do modelo lógite multinomial estimados por máxima verossimilhança e ponderadas pelo fator de expansão da amostra, para homens e mulheres, nas áreas rurais estão apresentados, nas Tabelas 28 e 29, respectivamente. Os sinais dos efeitos marginais são semelhantes àqueles obtidos na área urbana. Algumas diferenças são apresentadas abaixo.

A idade do chefe de família que foi significativa em aumentar a probabilidade de os jovens estudarem, estando o estudo combinado com outra atividade ou não nas áreas urbanas, deixou de ser significativa nas áreas rurais, indicando que nessas áreas o trabalho é mais valorizado do que o estudo. Ademais, observa-se que o efeito da escolaridade do chefe de família em aumentar a probabilidade de o jovem só estudar é maior nas áreas urbanas do que nas áreas rurais.

Na equação dos homens (Tabela 28), o fato de o chefe da família do jovem ser do sexo masculino aumenta a probabilidade de o jovem trabalhar, independente de estudar ou não, em relação à chefe mulher. Tal resultado parece contraditório, uma vez que se sabe que o chefe é responsável pela maior parte do orçamento familiar e que os rendimentos auferidos pelas mulheres é substancialmente inferior ao dos homens. Considerando estas questōes, seria natural deduzir que os jovens, cujos chefes de família são mulheres, teriam que ofertar mais seu trabalho, comparativamente aos demais jovens, buscando complementação da renda familiar. Portanto, o resultado, também observado por Kassouf (1999), mostra que a mulher prioriza a formação dos jovens. Outros pesquisadores mostraram que a renda auferida pelas mães surte maior efeito positivo sobre o estado nutricional dos filhos e na distribuição da alimentação dentro do domicílio em relação aos pais [Senauer, Garcia e Jacinto (1988)]. 
Tabela 28. Equações de trabalho e frequiência à escola para homens jovens, com residência rural.

\begin{tabular}{|c|c|c|c|c|c|c|}
\hline Variáveis & $\begin{array}{l}\text { Só estuda } \\
\text { (referência) }\end{array}$ & Só trabalha & $\begin{array}{l}\text { Estuda e cuida } \\
\text { de afazeres } \\
\text { domésticos }\end{array}$ & $\begin{array}{l}\text { Estuda e } \\
\text { Trabalha }\end{array}$ & $\begin{array}{l}\text { Só cuida de } \\
\text { afazeres } \\
\text { domésticos }\end{array}$ & $\begin{array}{c}\text { Não estuda } \\
\text { nem trabalha }\end{array}$ \\
\hline Constante & 0,108 & $\frac{-1,004}{(-6,52)^{* * *}}$ & $\begin{array}{c}0,177 \\
(1,77)^{*}\end{array}$ & $\begin{array}{l}0,891 \\
(0,20)\end{array}$ & $\begin{array}{l}-0,0494 \\
(-4,86)^{* * *}\end{array}$ & $\begin{array}{c}-0,123 \\
(-6,81)^{* * *}\end{array}$ \\
\hline Idade & $-0,0117$ & $\begin{array}{c}0,0851 \\
(15,93)^{* * *}\end{array}$ & $\begin{array}{c}-0,0139 \\
(-0,59)\end{array}$ & $\begin{array}{c}-0,0613 \\
(4,57)^{* * *}\end{array}$ & $\begin{array}{l}0,000801 \\
(9,50)^{* * *}\end{array}$ & $\begin{array}{l}0,000985 \\
(10,00)^{* * *}\end{array}$ \\
\hline Branco & 0,0214 & $\begin{array}{l}-0,0451 \\
(-1,92)^{*}\end{array}$ & $\begin{array}{c}-0,00397 \\
(-1,80)^{*}\end{array}$ & $\begin{array}{l}0,0481 \\
(-1,27)\end{array}$ & $\begin{array}{c}-0,00434 \\
(-1,69)^{*}\end{array}$ & $\begin{array}{l}-0,0160 \\
(-2,36)^{* *}\end{array}$ \\
\hline Pardo & 0,0247 & $\begin{array}{l}-0,0339 \\
(-2,18)^{* *}\end{array}$ & $\begin{array}{l}-0,0119 \\
(-2,60)^{* *}\end{array}$ & $\begin{array}{l}0,0418 \\
(-1,62)\end{array}$ & $\begin{array}{l}-0,0138 \\
(-2,57)^{* *}\end{array}$ & $\begin{array}{l}-0,00703 \\
(-2,14)^{* *}\end{array}$ \\
\hline $\begin{array}{l}\text { Escolaridade do } \\
\text { chefe }\end{array}$ & 0,00402 & $\begin{array}{l}-0,0279 \\
(-6,79)^{* * *}\end{array}$ & $\begin{array}{l}0,00692 \\
(2,48)\end{array}$ & $\begin{array}{c}0,00965 \\
(-3,73))^{* * *}\end{array}$ & $\begin{array}{c}0,00293 \\
(-0,89)\end{array}$ & $\begin{array}{c}0,00439 \\
(-0,30)\end{array}$ \\
\hline Idade do chefe & 0,000367 & $\begin{array}{l}-0,00402 \\
(-3,05)^{* * *}\end{array}$ & $\begin{array}{c}0,000668 \\
(1,00)\end{array}$ & $\begin{array}{c}0,00227 \\
(-0,56)\end{array}$ & $\begin{array}{l}-0,000184 \\
(-1,99)^{* *}\end{array}$ & $\begin{array}{c}0,000897 \\
(1,51)\end{array}$ \\
\hline Chefe homem & $-0,00963$ & $\begin{array}{l}0,0745 \\
(2,27)^{* *}\end{array}$ & $\begin{array}{c}-0,0195 \\
(-1,16)\end{array}$ & $\begin{array}{c}0,00927 \\
(1,81)^{*}\end{array}$ & $\begin{array}{l}-0,0288 \\
(-2,48)^{* *}\end{array}$ & $\begin{array}{r}-0,0257 \\
(-1,57)\end{array}$ \\
\hline $\begin{array}{l}N^{\circ} \text { de pessoas na } \\
\text { familia }<8 \text { anos }\end{array}$ & $-0,00570$ & $\begin{array}{l}0,0290 \\
(2,51)^{* *}\end{array}$ & $\begin{array}{l}-0,00891 \\
(-0,61)^{* *}\end{array}$ & $\begin{array}{c}-0,0149 \\
(1,40)\end{array}$ & $\begin{array}{c}-0,00225 \\
(0,79)\end{array}$ & $\begin{array}{l}0,00276 \\
(2,14)^{* *}\end{array}$ \\
\hline $\begin{array}{l}N^{\circ} \text { de pessoas na } \\
\text { famillia }>7 \text { anos }\end{array}$ & 0,00125 & $\begin{array}{l}-0,0203 \\
(-2,02)^{* *}\end{array}$ & $\begin{array}{c}-0,00137 \\
(-1,70)^{*}\end{array}$ & $\begin{array}{c}0,0168 \\
(0,62)\end{array}$ & $\begin{array}{c}0,000745 \\
(-0,29)\end{array}$ & $\begin{array}{c}0,00285 \\
(-0,77)\end{array}$ \\
\hline Renda per capita & 0,0000461 & $\begin{array}{l}-0,000192 \\
(-4,40)^{* * *}\end{array}$ & $\begin{array}{c}0,0000165 \\
(-2,55)^{* *}\end{array}$ & $\begin{array}{l}0,000211 \\
(-2,16)^{* *}\end{array}$ & $\begin{array}{c}-0,00000941 \\
(-2,17)^{* *}\end{array}$ & $\begin{array}{c}-0,0000721 \\
(-3,16)^{* * *}\end{array}$ \\
\hline Região Norte & 0,00901 & $\begin{array}{l}0,0725 \\
(-0,30)\end{array}$ & $\begin{array}{l}0,0132 \\
(0,13)\end{array}$ & $\begin{array}{c}-0,0250 \\
(-0,65)\end{array}$ & $\begin{array}{l}0,0123 \\
(0,14)\end{array}$ & $\begin{array}{c}-0,0821 \\
(-1,23)\end{array}$ \\
\hline Região Sul & $-0,0344$ & $\begin{array}{c}0,133 \\
(4,69)^{* * *}\end{array}$ & $\begin{array}{c}-0,0221 \\
(1,44)\end{array}$ & $\begin{array}{l}-0,0417 \\
(3,39)^{* * *}\end{array}$ & $\begin{array}{c}-0,0176 \\
(1,36)\end{array}$ & $\begin{array}{l}-0,0170 \\
(1,68)^{*}\end{array}$ \\
\hline Região Sudeste & 0,00671 & $\begin{array}{c}0,111 \\
(-0,23)\end{array}$ & $\begin{array}{c}0,00341 \\
(-0,62)\end{array}$ & $\begin{array}{c}-0,130 \\
(-4,46)^{* * *}\end{array}$ & $\begin{array}{c}0,00124 \\
(-0,73)\end{array}$ & $\begin{array}{c}0,00704 \\
(-0,12)\end{array}$ \\
\hline $\begin{array}{l}\text { Região Centro- } \\
\text { Oeste }\end{array}$ & $-0,00262$ & $\begin{array}{l}0,0915 \\
(0,85)\end{array}$ & $\begin{array}{l}-0,0284 \\
(-1,88)^{*}\end{array}$ & $\begin{array}{c}-0,0598 \\
(-0,50)\end{array}$ & $\begin{array}{c}-0,0000809 \\
(0,20)\end{array}$ & $\begin{array}{c}-0,000590 \\
(0,17)\end{array}$ \\
\hline $\begin{array}{l}\text { Observações } \\
\text { Teste mult. } \\
\text { Lagrange }\end{array}$ & $\begin{array}{c}5.922 \\
2.012,09^{* * *}\end{array}$ & & & & & \\
\hline
\end{tabular}


Tabela 29. Equações de trabalho e freqüência à escola para mulheres jovens, com residência rural.

\begin{tabular}{|c|c|c|c|c|c|c|}
\hline Variáveis & $\begin{array}{l}\text { Só estuda } \\
\text { (referência) }\end{array}$ & Só trabalha & $\begin{array}{l}\text { Estuda e cuida } \\
\text { de afazeres } \\
\text { domésticos }\end{array}$ & $\begin{array}{l}\text { Estuda e } \\
\text { Trabalha }\end{array}$ & $\begin{array}{l}\text { Só cuida de } \\
\text { afazeres } \\
\text { domésticos }\end{array}$ & $\begin{array}{c}\text { Não estuda } \\
\text { nem trabalha }\end{array}$ \\
\hline Constante & 0,00768 & $\begin{array}{l}-0,672 \\
(-2,13)^{* *}\end{array}$ & $\begin{array}{c}0,705 \\
(2,55)^{* * *}\end{array}$ & $\begin{array}{l}0,145 \\
(0,16)\end{array}$ & $\begin{array}{l}-0,170 \\
(-1,10)\end{array}$ & $\begin{array}{l}-0,0161 \\
(-1,10)\end{array}$ \\
\hline Idade & $-0,00261$ & $\begin{array}{c}0,0516 \\
(8,05)^{* * *}\end{array}$ & $\begin{array}{c}-0,0493 \\
(0,17)\end{array}$ & $\begin{array}{l}-0,0220 \\
(2,43)^{* *}\end{array}$ & $\begin{array}{l}0,0230 \\
(6,78)^{* * *}\end{array}$ & $\begin{array}{l}-0,000700 \\
(3,78)^{* * *}\end{array}$ \\
\hline Branco & 0,00344 & $\begin{array}{c}-0,0119 \\
(-0,66)\end{array}$ & $\begin{array}{c}-0,0423 \\
(-1,01)\end{array}$ & $\begin{array}{l}0,0206 \\
(-0,37)\end{array}$ & $\begin{array}{l}0,0414 \\
(-0,40)\end{array}$ & $\begin{array}{c}-0,0111 \\
(-1,34)\end{array}$ \\
\hline Pardo & 0,00183 & $\begin{array}{c}-0,00928 \\
(-0,37)\end{array}$ & $\begin{array}{r}-0,0344 \\
(-0,66)\end{array}$ & $\begin{array}{c}0,00200 \\
(-0,30)\end{array}$ & $\begin{array}{c}0,0483 \\
(0,08)\end{array}$ & $\begin{array}{c}-0,00849 \\
(-0,92)\end{array}$ \\
\hline $\begin{array}{l}\text { Escolaridade do } \\
\text { chefe }\end{array}$ & 0,00128 & $\begin{array}{l}-0,00970 \\
(-4,76)^{* * *}\end{array}$ & $\begin{array}{c}0,0133 \\
(-1,93)^{*}\end{array}$ & $\begin{array}{c}0,00417 \\
(-3,11)^{* * *}\end{array}$ & $\begin{array}{l}-0,00890 \\
(-4,79)^{* * *}\end{array}$ & $\begin{array}{l}-0,000225 \\
(-2,81)^{* * *}\end{array}$ \\
\hline Idade do chefe & 0,000187 & $\begin{array}{l}-0,00393 \\
(-3,02)^{* * *}\end{array}$ & $\begin{array}{c}0,00451 \\
(0,49)\end{array}$ & $\begin{array}{c}0,00340 \\
(0,38)\end{array}$ & $\begin{array}{l}-0,00423 \\
(-3,26)^{* * *}\end{array}$ & $\begin{array}{l}0,0000618 \\
(-1,25)^{* *}\end{array}$ \\
\hline Chefe homem & $-0,00225$ & $\begin{array}{c}0,0235 \\
(0,93)\end{array}$ & $\begin{array}{c}-0,0537 \\
(-0,17)\end{array}$ & $\begin{array}{c}-0,0421 \\
(-0,16)\end{array}$ & $\begin{array}{c}0,0778 \\
(1,46)\end{array}$ & $\begin{array}{c}-0,00319 \\
(0,18)\end{array}$ \\
\hline $\begin{array}{l}N^{\circ} \text { de pessoas na } \\
\text { familia }<8 \text { anos }\end{array}$ & $-0,00126$ & $\begin{array}{r}0,0129 \\
(1,23)\end{array}$ & $\begin{array}{c}-0,0379 \\
(-0,54)\end{array}$ & $\begin{array}{c}-0,0183 \\
(0,05)\end{array}$ & $\begin{array}{l}0,0480 \\
(2,03)^{* *}\end{array}$ & $\begin{array}{l}-0,00343 \\
(-0,23)^{* *}\end{array}$ \\
\hline $\begin{array}{l}N^{\circ} \text { de pessoas na } \\
\text { familia }>7 \text { anos }\end{array}$ & 0,00184 & $\begin{array}{l}-0,00203 \\
(-3,64)^{* * *}\end{array}$ & $\begin{array}{l}0,0221 \\
(-1,40)\end{array}$ & $\begin{array}{l}0,0274 \\
(-0,12)\end{array}$ & $\begin{array}{l}-0,0481 \\
(-5,98)^{* * *}\end{array}$ & $\begin{array}{l}-0,00109 \\
(-3,01)^{* * *}\end{array}$ \\
\hline RFM-RTBR & 0,0000148 & $\begin{array}{l}-0,000229 \\
(-3,80)^{* * *}\end{array}$ & $\begin{array}{c}0,000159 \\
(-1,54)\end{array}$ & $\begin{array}{l}0,0000272 \\
(-2,52)^{* *}\end{array}$ & $\begin{array}{l}0,0000667 \\
(-2,55)^{* * *}\end{array}$ & $\begin{array}{l}-0,0000380 \\
(-2,08)^{* * *}\end{array}$ \\
\hline Região Norte & $-0,108$ & $\begin{array}{r}0,0191 \\
(0,06)\end{array}$ & $\begin{array}{c}0,0432 \\
(0,06)\end{array}$ & $\begin{array}{c}0,0831 \\
(0,06)\end{array}$ & $\begin{array}{c}-0,0402 \\
(0,06)\end{array}$ & $\begin{array}{c}0,00305 \\
(0,06)\end{array}$ \\
\hline Região Sul & $-0,00994$ & $\begin{array}{c}0,133 \\
(3,33)^{* * *}\end{array}$ & $\begin{array}{c}-0,0690 \\
(1,63)\end{array}$ & $\begin{array}{c}0,0460 \\
(3,27)^{* * *}\end{array}$ & $\begin{array}{l}-0,0946 \\
(1,84)^{* *}\end{array}$ & $\begin{array}{c}-0,00502 \\
(1,38)\end{array}$ \\
\hline Região Sudeste & $-0,00444$ & $\begin{array}{c}-0,00564 \\
(1,70)^{*}\end{array}$ & $\begin{array}{c}-0,0228 \\
(1,27)\end{array}$ & $\begin{array}{c}-0,0276 \\
(1,00)\end{array}$ & $\begin{array}{l}0,0451 \\
(2,19)^{* *}\end{array}$ & $\begin{array}{c}0,0103 \\
(2,80)^{* * *}\end{array}$ \\
\hline $\begin{array}{l}\text { Região Centro- } \\
\text { Oeste }\end{array}$ & $-0,00849$ & $\begin{array}{l}0,0628 \\
(1,90)^{*}\end{array}$ & $\begin{array}{c}-0,0299 \\
(1,33)\end{array}$ & $\begin{array}{c}-0,0231 \\
(1,30)\end{array}$ & $\begin{array}{c}-0,00474 \\
(1,58)\end{array}$ & $\begin{array}{c}0,00344 \\
(1,56)\end{array}$ \\
\hline $\begin{array}{l}\text { Observações } \\
\text { Teste mult. } \\
\text { Lagrange }\end{array}$ & $\begin{array}{c}5.266 \\
2.265,48^{* * *}\end{array}$ & & & & & \\
\hline
\end{tabular}

Obs: Testes t estão entre parênteses abaixo dos efeitos marginais.

${ }^{* * *}$ Denota significância ao nível de $1 \%$

** Denota significância ao nível de $5 \%$

* Denota significância ao nível de $10 \%$ 


\subsection{Equações de inatividade, emprego e desemprego para jovens}

Esta seção analisa o modelo lógite multinomial para as probabilidades de o jovem se encontrar em uma das três condições: inativo, empregado ou desempregado. No modelo lógite multinomial considera-se todas as alternativas simultaneamente. A análise do impacto de cada variável explanatória na probabilidade de o indivíduo encontrar-se empregado e desempregado é realizada relativamente ao impacto na probabilidade de o jovem encontrar-se inativo, cuja alternativa é a referência. Vale lembrar que indivíduos inativos são todos aqueles que não tinham trabalho e não tinham procurado pelo mesmo na semana de referência (exemplos: dona de casa que possui como atividade exclusiva os afazeres domésticos e cuidados com os filhos, estudantes que se dedicam exclusivamente ao estudo, deficientes físicos e mentais incapazes de exercer qualquer tipo de trabalho, etc...). Indivíduos empregados são todos aqueles que rabalharam ou tinham trabalho na semana de referência da pesquisa e, indivíduos desempregados são aqueles que não tinham trabalho, mas que procuraram pelo mesmo na semana de referência.

Tendo em vista alguns resultados obtidos nas equações de inatividade, emprego e desemprego, que a princípio não confirmaram as hipóteses levantadas e para facilitar a interpretação dos coeficientes, estimou-se para as probabilidades de inatividade e desemprego, modelos próbite binomial, no qual a variável dependente também possui natureza discreta (da mesma forma como o modelo lógite multinomial), mas assume apenas dois valores, 0 ou 1. Para efeitos de comparação, da mesma forma como foi feito para a estimação do modelo lógite multinomial, separou-se os indivíduos em homens e mulheres residentes nas áreas urbanas e rurais. Foram estimados dois modelos próbite binomial. O primeiro modelo trata da condição de atividade dos jovens, ou seja, divide a amostra de jovens em duas, ativos e inativos. A variável dependente, neste caso, assume valor 0 se o jovem é ativo e 1 se o jovem é inativo. O segundo modelo trata da condição de ocupação dos jovens, portanto, este modelo trabalha apenas com os jovens ativos e os classifica como ocupados (empregados) ou desocupados (desempregados). Neste modelo a variável dependente assume o valor 0 para indivíduos 
empregados e 1 para indivíduos desempregados. Os resultados encontram-se nas Tabelas A1 e A2, em apêndice, serão mencionados juntamente com os resultados do modelo multinomial.

Os resultados obtidos a partir do modelo próbite binomial, em geral, confirmaram os resultados obtidos no modelo lógite multinomial. Nas probabilidades de inatividade praticamente todas as variáveis apresentaram efeitos marginais com o mesmo sinal nos dois modelos. Nas probabilidades de desemprego, para todos os homens, e para as mulheres das áreas rurais todas as variáveis apresentaram efeito no mesmo sentido em ambos os modelos. Já para as mulheres das áreas urbanas observouse algumas diferenças entre os dois modelos. Na equação estimada para as áreas urbanas obteve-se seis variáveis cujos efeitos marginais para os dois modelos apresentaram efeitos opostos, entretanto, observa-se que apenas a constante e a variável escolaridade foram significativas nos dois modelos, as demais (educexp, cônjuge, número de pessoas na família com menos de 8 anos e região Norte) foram não significativas no modelo lógite ou no modelo próbite ou em ambos.

Pode-se dizer, portanto, que as diferenças obtidas entre os dois modelos deve-se crucialmente à eliminação dos indivíduos inativos na estimação da probabilidade de desemprego, cuja proporção é mais elevada para as mulheres do que para os homens, $49,5 \%$ e $24,9 \%$, respectivamente, o que resultou em algumas alterações nos resultados das probabilidades de desemprego apenas para as mulheres.A Tabela 30 mostra a porcentagem de jovens na amostra de acordo com sua condição de atividade no período de referência da pesquisa. Os resultados mostram que as taxas de inatividade são maiores para as mulheres do que para os homens e maior nas áreas urbanas do que nas rurais. A porcentagem de jovens empregados é maior nas áreas rurais do que nas áreas urbanas e existe menor porcentagem de mulheres empregadas do que homens. Ademais, a porcentagem de jovens desempregados é substancialmente superior nas áreas urbanas comparativamente às rurais e ligeiramente superior para as mulheres em relação aos homens. 
Tabela 30. Porcentagem de jovens de 15 a 24 anos de acordo com sua condição de atividade no período de 20 a 26 de setembro de 1998.

\begin{tabular}{lcccc}
\hline & \multicolumn{2}{c}{ Urbano } & \multicolumn{2}{c}{ Rural } \\
\cline { 2 - 5 } & Homens & Mulheres & Homens & Mulheres \\
\hline Inativo & 28,0 & 49,6 & 12,9 & 49,1 \\
Empregado & 60,0 & 37,7 & 83,2 & 46,1 \\
Desempregado & 12,0 & 12,7 & 3,9 & 4,8 \\
\hline
\end{tabular}

Fonte: PNAD/IBGE, 1998 (microdados).

\subsubsection{Equações de inatividade, emprego e desemprego para homens jovens das áreas urbanas}

A Tabela 31 apresenta os resultados das equações de inatividade, emprego e desemprego, para homens jovens, com idade entre 15 e 24 anos, residindo no setor urbano. Nela estão apresentados os efeitos marginais e os testes-t entre parênteses.

O vetor de variáveis exógenas incluídas nesta análise são: escolaridade, experiência, experiência ao quadrado, variável de interação entre experiência e escolaridade (educexp), variáveis binárias para grupos de cor (parda, branca e preta variável omitida), variáveis binárias para posição ocupada pelo jovem na família (filho, outros e chefe - variável omitida), número de pessoas na família com sete anos ou menos de idade, número de pessoas na família com oito anos ou mais de idade, renda familiar per capita e variáveis binárias para a região de residência ( Região Norte, Região Sul, Região Sudeste, Região Centro-Oeste e Região Nordeste - variável omitida).

Os coeficientes obtidos do modelo lógite multinomial não são fáceis de interpretar, pois não representam diretamente as respostas marginais como no método dos Mínimos Quadrados Ordinários. Desta forma, a análise se dará, essencialmente, a partir dos efeitos marginais de cada variável explanatória. Os efeitos marginais são computados na média das variáveis explanatórias (ver equação 4 da seção 5). Eles mostram a mudança na probabilidade, expressa em pontos percentuais, devido ao acréscimo de uma unidade na média de uma dada variável explanatória, enquanto todas as outras variáveis são mantidas constantes. 
Pode-se observar que, para o caso das probabilidades de desemprego, dos dezesseis coeficientes estimados quatorze mostram-se estatisticamente significativos, enquanto que nas probabilidades de emprego seis variáveis (educexp, as duas de cor, as duas representando o número de pessoas na família e a região Norte) não foram estatisticamente significativas. Das quatorze variáveis significativas na equação de desemprego, sete apresentou efeitos marginais com o mesmo sinal da equação de inatividade. Isso sugere que, de modo geral, as variáveis que aumentam a probabilidade de um indivíduo encontrar-se desempregado também o fazem em relação à inatividade. No que concerne ao emprego observa-se o oposto, apenas duas variáveis significativas tiveram o efeito marginal com o mesmo sinal da equação de inatividade, indicando que, as variáveis que aumentam a probabilidade de emprego diminuem a probabilidade de inatividade. Da mesma forma, as equações de emprego e desemprego apresentaram apenas três variáveis, das dezesseis, com o mesmo sinal nos efeitos marginais, indicando que variáveis que aumentam a probabilidade do jovem encontrar-se empregado diminui a probabilidade de ele encontrar-se desempregado. 
Tabela 31. Equações de inatividade, emprego e desemprego para homens jovens, com residência urbana.

\begin{tabular}{|c|c|c|c|}
\hline Variáveis & $\begin{array}{c}\text { Inativo } \\
\text { (referência) }\end{array}$ & Empregado & Desempregado \\
\hline Constante & 0,117 & $\begin{array}{l}-0,139 \\
(-7,45)^{\cdots \cdots}\end{array}$ & $\begin{array}{c}0,0224 \\
(-5,02) \cdots\end{array}$ \\
\hline Escolaridade & $-0,00824$ & $\begin{array}{l}0,00922 \\
(9,44)^{* \cdots}\end{array}$ & $\begin{array}{c}-0,000978 \\
(6,78)^{* \cdots}\end{array}$ \\
\hline Experiência & $-0,131$ & $\begin{array}{c}0,200 \\
(53,73)^{* * *}\end{array}$ & $\begin{array}{c}-0,0692 \\
(22,01)^{* * *}\end{array}$ \\
\hline Experiência ao quadrado & 0,00727 & $\begin{array}{c}-0,0107 \\
(-51,43)^{* * *}\end{array}$ & $\begin{array}{c}0,00347 \\
(-21,98)^{* *}\end{array}$ \\
\hline Educação * Experiência & $-0,000362$ & $\begin{array}{c}-0,0000446 \\
(1,32)\end{array}$ & $\begin{array}{c}0,000407 \\
(2,25)^{*}\end{array}$ \\
\hline Branco & $-0,00295$ & $\begin{array}{l}0,0558 \\
(1,09)\end{array}$ & $\begin{array}{l}-0,0528 \\
(-3,58)^{* * *}\end{array}$ \\
\hline Pardo & 0,00153 & $\begin{array}{c}0,0262 \\
(0,25)\end{array}$ & $\begin{array}{l}-0,0278 \\
(-2,15)^{* *}\end{array}$ \\
\hline Filho & 0,0854 & $\begin{array}{r}-0,112 \\
(-7,38)^{* *}\end{array}$ & $\begin{array}{c}0,0269 \\
(-4,12) \cdots\end{array}$ \\
\hline Outro & 0,0708 & $\begin{array}{l}-0,0885 \\
(-5,51)^{\cdots} \cdots\end{array}$ & $\begin{array}{c}0,0177 \\
(-3,31)^{\cdots *}\end{array}$ \\
\hline $\begin{array}{l}\mathrm{N}^{\circ} \text { de pessoas na família } \\
<8 \text { anos }\end{array}$ & $-0,00269$ & $\begin{array}{c}0,0113 \\
(1,03)\end{array}$ & $\begin{array}{c}-0,00864 \\
(-0,89)\end{array}$ \\
\hline $\begin{array}{l}N^{\circ} \text { de pessoas na família } \\
>7 \text { anos }\end{array}$ & 0,00244 & $\begin{array}{c}-0,00103 \\
(-1,48)\end{array}$ & $\begin{array}{c}-0,00141 \\
(-1,90)^{*}\end{array}$ \\
\hline Renda familiar per capita & 0,0000648 & $\begin{array}{c}0,0000596 \\
(-7,54)^{\cdots \cdots}\end{array}$ & $\begin{array}{l}-0,000124 \\
(-13,25)^{* *}\end{array}$ \\
\hline Região Norte & 0,00637 & $\begin{array}{r}-0,0140 \\
(-0,79)\end{array}$ & $\begin{array}{c}0,00759 \\
(-0,02)\end{array}$ \\
\hline Região Sul & $-0,0332$ & $\begin{array}{l}0,0160 \\
(3,94)^{* *}\end{array}$ & $\begin{array}{r}0,0172 \\
(4,67)^{* \cdots}\end{array}$ \\
\hline Região Sudeste & $-0,0264$ & $\begin{array}{l}-0,00597 \\
(3,83)^{\cdots}\end{array}$ & $\begin{array}{c}0,0323 \\
(7,34)^{\cdots} \cdots\end{array}$ \\
\hline Região Centro-Oeste & $-0,0319$ & $\begin{array}{l}0,00866 \\
(3,12)^{* *}\end{array}$ & $\begin{array}{l}0,0233 \\
(4,40)^{* *}\end{array}$ \\
\hline $\begin{array}{l}\text { Observações } \\
\text { Teste mult. Lagrange }\end{array}$ & $\begin{array}{c}26.436 \\
17.115,93\end{array}$ & & \\
\hline
\end{tabular}

Obs: Testes t estão entre parênteses abaixo dos efeitos marginais.

** Denota significância ao nível de $1 \%$

** Denota significância ao nível de 5\%

* Denota significância ao nível de $10 \%$ 
Na Tabela A1, em apêndice, encontram-se os resultados das equações de inatividade e desemprego para os homens obtidos a partir do modelo próbite binomial. Esses resultados vieram a confirmar os resultados do modelo lógite multinomial, visto que nas equações de desemprego todas as variáveis apresentaram efeitos marginais no mesmo sentido em ambos os modelos, e, nas equações de inatividade apenas duas variáveis tiveram efeitos opostos ao obtido no modelo lógite multinomial.

Os resultados mostraram que a escolaridade e a experiência contribuem para aumentar a probabilidade de o jovem encontrar-se empregado e para diminuir a probabilidade de outras alternativas. O aumento do estoque de capital humano, aqui representado pelas variáveis escolaridade e experiência, significa aumento de produtividade, o que reflete em maior probabilidade de obtenção de emprego, bem como aumento nos rendimentos auferidos pelos trabalhadores, o que, tudo mais constante, afeta positivamente a decisão do indivíduo se inserir no mercado de trabalho, bem como as estratégias adotadas na busca por um trabalho. Tudo isso resulta em queda na probabilidade de inatividade e desemprego do jovem e aumento na sua probabilidade de emprego.

Observa-se que o efeito da experiência é bem maior que o efeito da escolaridade em aumentar a probabilidade de o jovem estar empregado. Enquanto o aumento de um ano de experiência aumenta $20 \%$ a probabilidade de o jovem encontrarse empregado, o aumento de um ano de escolaridade aumenta apenas em $1 \%$ essa mesma probabilidade. Ademais, a probabilidade de desemprego decresce em 7\% com o aumento de um ano de experiência e apenas em $0,1 \%$ com o aumento de um ano de escolaridade. Portanto, tem-se que, para os jovens, na faixa etária dos 15 aos 24 anos, o mercado de trabalho valoriza mais a experiência que a escolaridade. Talvez esse resultado possa ser explicado pela falta de experiência dos jovens, o que é natural para esta faixa etária, o que faz com que aqueles jovens que possuem alguma experiência estejam em situação de vantagem em relação aos demais. 
Fernandes e Picchetti (1999) analisaram a estrutura do desemprego e da inatividade do Brasil metropolitano a partir de dados da PNAD de 1995. A amostra usada pelos autores restringiu-se a indivíduos com 10 anos ou mais de idade, residentes em áreas metropolitanas. Portanto, não é possível fazer comparações entre os dois estudos, visto que os universos de análise são bastante distintos. Vale ressaltar, ainda, que os autores trabalharam com amostra única, não separando homens de mulheres. Entretanto, como é o único estudo existente nesta linha de pesquisa vale mencionar alguns resultados obtidos pelos autores.

Para a probabilidade de desemprego, Fernandes e Picchetti (1999) observaram que ela é inicialmente crescente com anos de estudo, atingindo um máximo com cerca de nove anos de estudo e, a partir daí, começando a decrescer. O comportamento observado para a probabilidade de inatividade foi decrescente com anos de estudo.

As variáveis binárias para os grupos de cor existentes no Brasil (branca, parda) foram incluídas nas equações de condição de atividade para refletir diferenças étnicas e valores culturais entre os indivíduos. O grupo de referência é o de cor preta (variável omitida na equação). Essas variáveis só foram significativas para a probabilidade de desemprego. Os resultados indicam que o jovem ser de cor branca ou parda contribui para diminuir a probabilidade de ele estar desempregado, o que vem confirmar os resultados obtidos na análise preliminar dos dados e indica a existência de discriminação racial no mercado de trabalho no preenchimento das vagas existentes.

Variáveis representando a posição ocupada pelo jovem na família (filho, outros e chefe - variável omitida) mostram que jovens cuja posição na família é a de filho tem probabilidade $2,7 \%$ mais elevada de estar desempregado e uma probabilidade 1,1\% menor de estar empregado do que o chefe de família. Tal resultado confirma a análise prévia dos dados, onde a taxa de desemprego masculina encontrada foi menor para os chefes de família. Os chefes de família são, de modo geral, responsáveis pelo orçamento familiar, o que, portanto, influencia na sua forma de inserção no mercado de 
trabalho e estratégia de busca de emprego, sendo esta mais agressiva e persistente, tendo em vista a necessidade de auferir alguma renda para manter sua família.

Fernandes e Picchetti (1999) verificaram que os chefes de família tinham menor probabilidade de inatividade, porém, maiores probabilidade de desemprego em relação aos seus cônjuges, os quais tinham menor probabilidade de desemprego que os filhos, e estes, por sua vez, menor probabilidade de inatividade que os cônjuges.

A variável renda familiar per capita mostra o comportamento das probabilidades de emprego e desemprego com relação ao suporte financeiro da família do jovem (renda familiar menos rendimentos do trabalho auferidos pelo jovem). Essa variável causou um aumento estatisticamente significativo na probabilidade de emprego e diminuição estatisticamente significativa na probabilidade de desemprego. A princípio acreditava-se que essa variável afetaria positivamente a probabilidade de desemprego e negativamente a probabilidade de emprego, tendo em vista que a mesma deve aumentar o salário reserva dos indivíduos e, quanto mais alto o salário reserva do indivíduo maior deve ser o salário exigido para este aceitar uma oferta de trabalho, o que, tudo mais constante, deveria aumentar sua probabilidade de desemprego.

$\mathrm{O}$ resultado, entretanto, indicou o contrário, portanto pode-se dizer que quanto maior é o suporte financeiro do indivíduo, maiores devem ser suas condições de formação e preparo para o mercado de trabalho, o que, tudo mais constante, deve aumentar o seu grau de empregabilidade. A qualidade do ensino não foi controlada na análise e pode estar sendo captada por outras variáveis, como a renda familiar per capita. Indivíduos com um bom suporte financeiro também têm mais condições de se tornar trabalhador autônomo abrindo negócio próprio, sendo este o caminho encontrado por muitos indivíduos para fugir do desemprego. Ademais, indivíduos mais ricos se relacionam com pessoas mais ricas e, portanto, possuem melhores contatos para conseguirem emprego. Observa-se ainda que quanto maior a renda familiar líquida maior a probabilidade de inatividade, pois quanto mais rica a família maior a condição de investir na formação de seus jovens sem precisar lançar mão de seu trabalho. 
Fernandes e Picchetti (1999) encontraram probabilidades de inatividade crescentes e probabilidade de desemprego decrescentes com o aumento da renda familiar.

As variáveis binárias para as cinco regiões brasileiras foram incluídas para verificar as diferenças regionais no que diz respeito às probabilidades de os jovens encontrarem-se empregados ou desempregados. A variável binária omitida foi a da região Nordeste. Em relação à probabilidade de emprego observa-se que o indivíduo residir na região Sudeste diminui a probabilidade de ele encontrar-se empregado, enquanto residir nas regiões Sul e Centro-Oeste faz com que aumente suas probabilidades de emprego, relativamente à região Nordeste. No que concerne ao desemprego, observa-se que, residir na região Nordeste diminui a probabilidade de desemprego dos jovens em relação às demais regiões do país.

A Tabela 32 mostra as taxas de inatividade, emprego e desemprego para homens jovens de 15 a 24 anos de idade estratificado por região, cujos resultados confirmam a maioria dos resultados econométricos obtidos para as variáveis binárias representando as regiões brasileiras. As regiões Sul e Centro-Oeste possuem as maiores taxas de emprego e a região Sudeste as maiores taxas de desemprego. A diminuição na probabilidade de desemprego para jovens residentes no Nordeste se dá em razão de esta região possuir a menor taxa de desemprego e a maior taxa de inatividade.

Tabela 32. Taxas de inatividade, emprego e desemprego, para homens jovens de 15 a 24 anos de idade, estratificado por região, em 1998.

\begin{tabular}{lccccc}
\hline & Norte & Nordeste & Centro-Oeste & Sudeste & Sul \\
\hline Inativos & 31,1 & 31,4 & 24,5 & 27,8 & 22,9 \\
Empregados & 57,9 & 57,7 & 63,6 & 59,1 & 66,2 \\
Desempregados & 11,0 & 10,9 & 11,9 & 13,1 & 10,9 \\
\hline
\end{tabular}

Fonte: PNAD/IBGE, 1998 (microdados). 


\subsubsection{Equações de inatividade, emprego e desemprego para mulheres jovens das áreas urbanas}

A Tabela 33 apresenta as equações de inatividade, emprego e desemprego para mulheres jovens com residência urbana. Em geral, as variáveis explanatórias tiveram alto poder explicativo, sendo que nas equações de probabilidade de emprego e desemprego, quatorze coeficientes, dos dezessete estimados, foram estatisticamente significativos.

Ao contrário das equações obtidas para os homens, residentes na área urbana, os resultados para as mulheres indicam que, no geral, as variáveis que aumentam a probabilidade de inatividade das mulheres jovens, residentes em áreas urbanas, diminui sua probabilidade de desemprego, bem como sua probabilidade de emprego. A princípio, parece contraditório que as mesmas variáveis afetem no mesmo sentido as probabilidades de emprego e desemprego. Procurar-se-á explicações para tal fenômeno no decorrer da análise. 
Tabela 33. Equações de inatividade, emprego e desemprego para mulheres jovens, com residência urbana.

\begin{tabular}{|c|c|c|c|}
\hline Variáveis & $\begin{array}{c}\text { Inativo } \\
\text { (referência) }\end{array}$ & Empregado & Desempregado \\
\hline Constante & 0,684 & $\begin{array}{c}-0,623 \\
(-24,57)^{* * *}\end{array}$ & $\begin{array}{c}-0,0607 \\
(-14,45)^{* * *}\end{array}$ \\
\hline Escolaridade & $-0,0386$ & $\begin{array}{c}0,0314 \\
(20,23)^{* * *}\end{array}$ & $\begin{array}{l}0,00722 \\
(14,91)^{* * *}\end{array}$ \\
\hline Experiência & $-0,253$ & $\begin{array}{c}0,263 \\
(58,71)^{* * *}\end{array}$ & $\begin{array}{l}-0,0112 \\
(17,71)^{* * *}\end{array}$ \\
\hline Experiência ao quadrado & 0,0137 & $\begin{array}{c}-0,0144 \\
(-53,89)^{* * *}\end{array}$ & $\begin{array}{l}0,000654 \\
(-15,60)^{* * *}\end{array}$ \\
\hline Educação * Experiência & 0,000985 & $\begin{array}{l}-0,000954 \\
(-2,72)^{* * *}\end{array}$ & $\begin{array}{c}-0,0000306 \\
(-1,03)\end{array}$ \\
\hline Branco & 0,0545 & $\begin{array}{l}0,0167 \\
(-0,75)\end{array}$ & $\begin{array}{l}-0,0711 \\
(-6,52)^{* * *}\end{array}$ \\
\hline Pardo & 0,0450 & $\begin{array}{c}-0,000870 \\
(-1,11)\end{array}$ & $\begin{array}{l}-0,0441 \\
(-4,2)^{* * *}\end{array}$ \\
\hline Filho & $-0,0148$ & $\begin{array}{l}0,0678 \\
(2,45)^{* *}\end{array}$ & $\begin{array}{l}-0,0530 \\
(-2,91)^{* * *}\end{array}$ \\
\hline Cônjuge & 0,212 & $\begin{array}{c}-0,158 \\
(-10,88)^{* * *}\end{array}$ & $\begin{array}{l}-0,0530 \\
(-9,23)^{* * *}\end{array}$ \\
\hline Outro & $-0,0962$ & $\begin{array}{c}0,162 \\
(6,65)^{* * *}\end{array}$ & $\begin{array}{l}-0,0656 \\
(1,68)^{*}\end{array}$ \\
\hline $\begin{array}{l}N^{\circ} \text { de pessoas na família } \\
<8 \text { anos }\end{array}$ & 0,0185 & $\begin{array}{l}-0,0160 \\
(-2,86)^{* * *}\end{array}$ & $\begin{array}{l}-0,00252 \\
(-1,73)^{*}\end{array}$ \\
\hline $\begin{array}{l}N^{\circ} \text { de pessoas na família } \\
>7 \text { anos }\end{array}$ & $-0,00492$ & $\begin{array}{l}0,00795 \\
(2,29)^{* *}\end{array}$ & $\begin{array}{c}-0,00303 \\
(-0,46)\end{array}$ \\
\hline Renda familiar per capita & 0,000191 & $\begin{array}{l}-0,0000822 \\
(-10,37)^{* * *}\end{array}$ & $\begin{array}{l}-0,000109 \\
(-11,75)^{* * *}\end{array}$ \\
\hline Região Norte & 0,0273 & $\begin{array}{c}-0,0262 \\
(-1,59)\end{array}$ & $\begin{array}{c}-0,00108 \\
(-0,69)\end{array}$ \\
\hline Região Sul & $-0,0668$ & $\begin{array}{c}0,0222 \\
(3,08)^{* * *}\end{array}$ & $\begin{array}{c}0,0446 \\
(5,54)^{* * *}\end{array}$ \\
\hline Região Sudeste & $-0,0584$ & $\begin{array}{l}0,000468 \\
(2,48)^{* *}\end{array}$ & $\begin{array}{l}0,0580 \\
(8,70)^{* * *}\end{array}$ \\
\hline Região Centro-Oeste & $-0,0518$ & $\begin{array}{l}0,0222 \\
(2,22)^{* *}\end{array}$ & $\begin{array}{c}0,0296 \\
(3,31)^{* * *}\end{array}$ \\
\hline $\begin{array}{l}\text { Observações } \\
\text { Teste mult. Lagrange }\end{array}$ & $\begin{array}{c}27.576 \\
16.882,20\end{array}$ & & \\
\hline
\end{tabular}

Obs: Testes t estão entre parênteses abaixo dos efeitos marginais.

*** Denota significância ao nível de $1 \%$

** Denota significância ao nível de $5 \%$

* Denota significância ao nível de $10 \%$ 
Os resultados da Tabela 33 mostram que a escolaridade contribui para aumentar a probabilidade de emprego e desemprego das mulheres jovens e para diminuir a probabilidade de inatividade. A diminuição da probabilidade de inatividade reflete o efeito do salário na atratividade do mercado de trabalho, ou seja, o aumento na escolaridade eleva o nível de capital humano, o que tende a afetar positivamente o nível salarial, o qual, tudo mais constante, deve elevar a atratividade do mercado. $\mathrm{O}$ aumento do emprego deve-se ao aumento de produtividade a cada ano adicional de estudo, o que afeta positivamente o grau de empregabilidade da jovem. O aumento na probabilidade de desemprego com incrementos na escolaridade é um fenômeno de difícil explicação. Este resultado, que não é o esperado, não foi observado no modelo próbite binomial. As simulações condicionadas à participação na força de trabalho, ou seja, utilizando apenas a mulheres jovens ativas, mostraram que a probabilidade de desemprego, condicionada à atividade das mulheres jovens, diminui com incrementos na escolaridade, como pode ser visto na Tabela A2, em apêndice. Tal alteração no resultado deve-se à eliminação das mulheres inativas da amostra, as quais perfaziam um total de 49,9\%.

O efeito da experiência sobre as probabilidades de inatividade, emprego e desemprego para as mulheres jovens foi o mesmo encontrado para os homens, isto é, a experiência contribui para aumentar a probabilidade da mulher jovem encontrar emprego e para diminuir a probabilidade de inatividade e desemprego. Entretanto, observa-se que o efeito da experiência sobre a probabilidade de emprego é mais forte para as mulheres do que para os homens. Enquanto o aumento de um ano de experiência para os homens aumenta em $20 \%$ a probabilidade de o jovem encontrar-se empregado, para as mulheres esse incremento é de $26 \%$.

Os resultados obtidos para as variáveis representando a cor das mulheres jovens foram os mesmos obtidos para os homens, mostrando que a discriminação racial no mercado de trabalho no preenchimento das vagas existentes é generalizado, não fazendo distinção entre homens e mulheres. As mulheres jovens de cor preta possuem maior probabilidade de desemprego que as brancas e pardas. Ademais, observa-se que o 
efeito da cor preta em aumentar a probabilidade de desemprego é maior para as mulheres do que para os homens.

Os resultados obtidos para as variáveis representando a posição ocupada pelo jovem na família foram o oposto daquele obtido para os homens. A jovem que ocupa a posição de filha tem probabilidade $7 \%$ mais elevada de emprego e probabilidade 5\% menor de desemprego que a chefe de família. A posição de cônjuge aumenta em $21 \%$ a probabilidade de inatividade da mulher jovem, o que se deve à maior responsabilidade destas jovens nos cuidados com os filhos e com os afazeres domésticos, bem como o suporte financeiro que têm por parte do marido. O efeito negativo desta variável na probabilidade de desemprego é de difícil explicação. Esperava-se que a variável cônjuge afetasse positivamente a probabilidade de desemprego. Acreditava-se que devido à maior responsabilidade da cônjuge no lar seu salário reserva fosse mais alto e portanto, esta exigiria salário maior para aceitar uma oferta de trabalho o que deveria aumentar sua probabilidade de desemprego. Também existe a discriminação no mercado de trabalho contra as mulheres, principalmente para as casadas, pois estas têm alguns direitos distintos dos homens, como a licença à maternidade que no Brasil é de quatro meses. Além disso, as mulheres que têm filhos estão mais suscetíveis às faltas ao trabalho ou a saídas no meio do expediente por causa de alguma emergência com seus filhos. Por tudo isso, geralmente, as empresas preferem contratar homens ou mulheres solteiras. Entretanto, o resultado obtido indica o oposto. Talvez, a diminuição da probabilidade de desemprego esteja relacionada com a baixa taxa de atividade para este segmento populacional, a qual é 42;8\% (Tabela 34).

Tabela 34. Porcentagem de indivíduos inativos, empregados e desempregados, para mulheres residentes nas áreas urbanas, estratificado por posição no domicílio.

\begin{tabular}{lcccc}
\hline & Chefe & Cônjuge & Filho & Outro \\
\hline Inativo & 35,8 & 57,2 & 50,1 & 39,4 \\
Empregado & 48,3 & 32,2 & 36,6 & 49,5 \\
Desempregado & 15,9 & 10,6 & 13,3 & 11,2 \\
\hline
\end{tabular}

Fonte: PNAD/IBGE, 1998 (microdados). 
De fato, nas simulações utilizando apenas as mulheres ativas (modelo próbite binomial) verificou-se que a posição de cônjuge afeta positivamente a probabilidade de desemprego da mulher jovem residente nas áreas urbanas. Entretanto, como se pode observar na Tabela $\mathrm{A} 2$, em apêndice, a variável não foi estatisticamente significativa.

As variáveis número de pessoas na família com sete ou menos anos de idade causou diminuição estatisticamente significativa na probabilidade de emprego e aumento na probabilidade de inatividade. A queda na probabilidade de emprego deve-se dar em função da necessidade de os jovens da família substituir seus pais e membros mais velhos nas atividades domésticas e cuidados com as crianças.

Para as mulheres jovens a variável renda familiar per capita causou diminuição estatisticamente significativa nas probabilidades de emprego e desemprego. Tal fenômeno deve-se ao efeito do salário reserva das mulheres jovens, para as quais o suporte financeiro por parte da família lhes permite postergar a entrada no mercado de trabalho, o que aumenta a taxa de inatividade e, portanto, diminui o congestionamento da busca por trabalho por este segmento da população, o que, tudo mais constante, diminui a sua probabilidade de emprego, bem como a probabilidade de desemprego, relativamente à probabilidade de inatividade. Tal resultado reforça a tese de que quanto mais renda disponível a jovem possuir mais tarde ela entrará no mercado de trabalho.

Os resultados obtidos para as variáveis binárias representando as regiões brasileiras (região Nordeste omitida) indicam que residir na região Nordeste aumenta a probabilidade de inatividade em relação às regiões Sul, Sudeste e Centro-Oeste, e, diminui a probabilidade de inatividade em relação à região Norte. Da mesma forma, residir na região Nordeste diminui a probabilidade de emprego e desemprego relativamente às demais regiões. Tais resultados são corroborados por aqueles obtidos nas estatísticas básicas, Tabela 2 , onde obteve-se maiores taxas de atividade para os jovens nas regiões Sul, Centro-Oeste e Sudeste. Como já foi dito anteriormente, a atividade dos jovens está intimamente relacionada à atratividade do mercado de 
trabalho, a qual é mais elevada nas mesmas regiões para as quais encontrou-se taxa de atividade mais alta. As menores probabilidades de emprego e desemprego na região Nordeste relativamente às demais regiões, deve-se à maior taxa de inatividade desta região, o que diminui o contigente deste segmento populacional à procura de emprego.

\subsubsection{Equações de inatividade, emprego e desemprego para jovens das áreas rurais}

Os resultados das equações de inatividade, emprego e desemprego dos jovens nas áreas rurais estão apresentados nas Tabelas 35 e 36, para homens e mulheres, respectivamente.

Para as probabilidades de inatividade e emprego os sinais dos efeitos marginais são muito semelhantes àqueles obtidos nas áreas urbanas. Entretanto, obtevese, para os homens das áreas rurais, na probabilidade de emprego, resultado oposto àquele obtido para homens das áreas urbanas, para uma variável considerada chave, nesta análise, a variável "escolaridade", a qual representa o número de anos de estudo completados pelos jovens. Obteve-se sinal negativo para a variável escolaridade na probabilidade de emprego nas áreas rurais o que implicaria em diminuição da probabilidade de emprego com o aumento no número de anos de estudo completados. No entanto, observa-se que a variável não foi estatisticamente significativa, indicando que para os homens jovens das áreas rurais essa variável não é fator determinante na probabilidade de o jovem obter emprego ou não, o que talvez se dê em função de falhas do sistema de ensino, o qual, na maior parte das vezes, não adapta a grade curricular à realidade rural.

Observa-se, para os homens, efeitos marginais da variável experiência substancialmente superior nas áreas urbanas do que nas rurais, o que indica que a experiência é mais valorizada nestas áreas do que nas rurais, visto que o trabalho urbano, geralmente, exige maior especialização por parte dos trabalhadores. Por exemplo, o aumento de um ano de experiência reduz a probabilidade de inatividade em 13,1\% nas 
áreas urbanas e em 3,8\% nas áreas rurais. A probabilidade de emprego, com o acréscimo de um ano de experiência aumenta em 20\% nas áreas urbanas e em 5,8\% nas áreas rurais. Para as mulheres os efeitos marginais da experiência são ligeiramente superiores nas áreas rurais em relação às áreas urbanas.

Analisando-se a magnitude dos efeitos marginais para a variável binária "filho" pode-se dizer que os jovens que ocupam a posição de filho na família estão mais propensos ao trabalho na zona rural do que na zona urbana. Por exemplo, enquanto nas áreas urbanas o filho tem probabilidade $8,5 \%$ maior que a do chefe de família de ser inativo, nas áreas rurais essa mesma probabilidade é de apenas 4,8\%. Para as mulheres verifica-se que a probabilidade de inatividade das filhas, nas áreas rurais, é 8,5\% menor que das chefes e, nas áreas urbanas é menor apenas 1,5\%.

Note que a renda familiar per capita, a qual foi altamente significativa nas equações de emprego das áreas urbanas, só foi estatisticamente significativa nas áreas rurais para as mulheres ao nível de $10 \%$.

Quanto à probabilidade de desemprego percebe-se que para os homens jovens $50 \%$ das variáveis afetam a probabilidade de desemprego na zona rural em direção oposta à da zona urbana, ou seja, 50\% dos sinais das variáveis explicativas para as áreas rurais são diferentes daqueles obtidos para as áreas urbanas. Por exemplo, enquanto para os homens jovens das áreas urbanas a escolaridade diminui a probabilidade de desemprego, para os jovens das áreas rurais o aumento na escolaridade eleva a probabilidade de desemprego. Este último resultado estaria indicando que os trabalhadores residentes nas áreas rurais com melhor formação ficam mais exigentes quanto ao trabalho e salário, não aceitando qualquer oferta de trabalho, o que pode elevar a duração do desemprego para este segmento populacional e, portanto, a sua taxa de desemprego. Para as mulheres os sinais dos efeitos marginais obtidos para as áreas rurais são muito semelhantes àqueles obtidos nas áreas urbanas. 
Tabela 35. Equações de inatividade, emprego e desemprego para homens jovens, com residência rural.

\begin{tabular}{|c|c|c|c|}
\hline Variáveis & $\begin{array}{c}\text { Inativo } \\
\text { (referência) }\end{array}$ & Empregado & Desempregado \\
\hline Constante & $-0,00434$ & $\begin{array}{r}0,0147 \\
(0,03)\end{array}$ & $\begin{array}{c}-0,00103 \\
(-0,04)\end{array}$ \\
\hline Escolaridade & $-0,000813$ & $\begin{array}{c}-0,00264 \\
(0,90)\end{array}$ & $\begin{array}{l}0,00345 \\
(4,39)^{* *}\end{array}$ \\
\hline Experiência & $-0,0376$ & $\begin{array}{c}0,0575 \\
(26,33)^{* * *}\end{array}$ & $\begin{array}{l}-0,0199 \\
(7,35)^{* * *}\end{array}$ \\
\hline Experiência ao quadrado & 0,00185 & $\begin{array}{l}-0,00280 \\
(-21,22) \cdots\end{array}$ & $\begin{array}{l}0,000945 \\
(-6,13)^{* \cdots}\end{array}$ \\
\hline Educação * Experiência & 0,0000852 & $\begin{array}{c}-0,000105 \\
(-0,57)\end{array}$ & $\begin{array}{c}0,0000197 \\
(-0,31)\end{array}$ \\
\hline Branco & 0,00908 & $\begin{array}{c}0,00570 \\
(-1,04)\end{array}$ & $\begin{array}{l}-0,0148 \\
(-2,61)^{* *}\end{array}$ \\
\hline Pardo & 0,0135 & $\begin{array}{l}0,00154 \\
(-1,61)^{*}\end{array}$ & $\begin{array}{l}-0,0150 \\
(-3,15)^{* \cdots}\end{array}$ \\
\hline Filho & 0,0482 & $\begin{array}{l}-0,0475 \\
(-4,08)^{\cdots}\end{array}$ & $\begin{array}{l}-0,000742 \\
(-3,50)^{* *}\end{array}$ \\
\hline Outro & 0,0389 & $\begin{array}{l}-0,0263 \\
(-3,02)^{* *}\end{array}$ & $\begin{array}{l}-0,0127 \\
(-3,32)^{* *}\end{array}$ \\
\hline $\begin{array}{l}N^{\circ} \text { de pessoas na família } \\
<8 \text { anos }\end{array}$ & $-0,00630$ & $\begin{array}{l}0,00755 \\
(2,64)^{* \cdots}\end{array}$ & $\begin{array}{c}-0,00125 \\
(1,46)\end{array}$ \\
\hline $\begin{array}{l}N^{\circ} \text { de pessoas na família } \\
>7 \text { anos }\end{array}$ & 0,000150 & $\begin{array}{c}0,00201 \\
(-0,08)\end{array}$ & $\begin{array}{c}-0,00216 \\
(-1,64)\end{array}$ \\
\hline Renda familiar per capita & $-0,00000103$ & $\begin{array}{l}0,0000445 \\
(0,24)\end{array}$ & $\begin{array}{c}-0,0000435 \\
(-2,23)^{* *}\end{array}$ \\
\hline Região Norte & $-0,0109$ & $\begin{array}{r}0,0309 \\
(0,73)\end{array}$ & $\begin{array}{c}-0,0199 \\
(-0,39)\end{array}$ \\
\hline Região Sul & $-0,0248$ & $\begin{array}{r}0,0405 \\
(3,99)^{* *}\end{array}$ & $\begin{array}{c}-0,0157 \\
(0,80)\end{array}$ \\
\hline Região Sudeste & $-0,0165$ & $\begin{array}{c}0,0132 \\
(3,67)^{* *}\end{array}$ & $\begin{array}{l}0,00328 \\
(3,42)^{* *}\end{array}$ \\
\hline Região Centro-Oeste & $-0,0113$ & $\begin{array}{l}0,0185 \\
(1,50)\end{array}$ & $\begin{array}{c}-0,00718 \\
(0,30)\end{array}$ \\
\hline $\begin{array}{l}\text { Observações } \\
\text { Teste mult. Lagrange }\end{array}$ & $\begin{array}{c}5.922 \\
2.845,03\end{array}$ & & \\
\hline
\end{tabular}

Obs: Testes $t$ estão entre parênteses abaixo dos efeitos marginais.

*** Denota significância ao nível de $1 \%$

** Denota significância ao nível de 5\%

* Denota significância ao nível de 10\% 
Tabela 36. Equações de inatividade, emprego e desemprego para mulheres jovens, com residência rural.

\begin{tabular}{|c|c|c|c|}
\hline Variáveis & $\begin{array}{c}\text { Inativo } \\
\text { (referência) }\end{array}$ & Empregado & Desempregado \\
\hline Constante & 0,874 & $\begin{array}{c}-0,793 \\
(-10,73)^{\cdots \cdots}\end{array}$ & $\begin{array}{l}-0,0804 \\
(-7,00)^{* \cdots}\end{array}$ \\
\hline Escolaridade & $-0,0387$ & $\begin{array}{c}0,0314 \\
(6,78)^{* *}\end{array}$ & $\begin{array}{l}0,00726 \\
(6,75)^{\cdots *}\end{array}$ \\
\hline Experiência & $-0,289$ & $\begin{array}{r}0,289 \\
(31,29)^{* *}\end{array}$ & $\begin{array}{l}-0,000531 \\
(7,84)^{* * *}\end{array}$ \\
\hline Experiência ao quadrado & 0,0138 & $\begin{array}{c}-0,0138 \\
(-25,14)^{* *}\end{array}$ & $\begin{array}{c}0,0000214 \\
(-5,58)^{* \cdots}\end{array}$ \\
\hline Educação * Experiência & 0,00307 & $\begin{array}{l}-0,00210 \\
(-2,97)^{* *}\end{array}$ & $\begin{array}{r}-0,000963 \\
(-3,02)^{* *}\end{array}$ \\
\hline Branco & 0,00186 & $\begin{array}{l}0,0126 \\
(0,12)\end{array}$ & $\begin{array}{c}-0,0127 \\
(-0,61)\end{array}$ \\
\hline Pardo & 0,0402 & $\begin{array}{c}-0,0494 \\
(-0,85)\end{array}$ & $\begin{array}{c}0,00924 \\
(0,20)\end{array}$ \\
\hline Filho & $-0,0850$ & $\begin{array}{r}0,144 \\
(1,93)^{*}\end{array}$ & $\begin{array}{l}-0,0597 \\
(-2,42)^{*}\end{array}$ \\
\hline Cônjuge & 0,0798 & $\begin{array}{r}-0,0169 \\
(-0,91)\end{array}$ & $\begin{array}{c}-0,0629 \\
(-4,47)^{\cdots *}\end{array}$ \\
\hline Outro & $-0,150$ & $\begin{array}{c}0,198 \\
(2,47)^{* *}\end{array}$ & $\begin{array}{r}-0,0485 \\
(-1,22)\end{array}$ \\
\hline $\begin{array}{l}\mathrm{N}^{\circ} \text { de pessoas na família } \\
<8 \text { anos }\end{array}$ & 0,00862 & $\begin{array}{c}-0,00148 \\
(-0,36)\end{array}$ & $\begin{array}{c}-0,00714 \\
(-1,37)\end{array}$ \\
\hline $\begin{array}{l}N^{\circ} \text { de pessoas na familia } \\
>7 \text { anos }\end{array}$ & $-0,0206$ & $\begin{array}{c}0,00510 \\
(0,48)\end{array}$ & $\begin{array}{c}-0,00304 \\
(-0,89)\end{array}$ \\
\hline Renda familiar per capita & 0,000111 & $\begin{array}{l}-0,000134 \\
(-1,70)^{*}\end{array}$ & $\begin{array}{l}0,0000223 \\
(0,39)\end{array}$ \\
\hline Região Norte & $-0,164$ & $\begin{array}{c}0,174 \\
(1,73)^{*}\end{array}$ & $\begin{array}{c}-0,0104 \\
(0,23)\end{array}$ \\
\hline Região Sul & $-0,107$ & $\begin{array}{l}0,0817 \\
(2,61)^{*}\end{array}$ & $\begin{array}{c}0,0256 \\
(2,74)^{* \cdots}\end{array}$ \\
\hline Região Sudeste & $-0,0343$ & $\begin{array}{c}-0,00597 \\
(0,46)\end{array}$ & $\begin{array}{l}0,0403 \\
(4,32)^{* * *}\end{array}$ \\
\hline Região Centro-Oeste & $-0,0706$ & $\begin{array}{l}0,0460 \\
(1,28)\end{array}$ & $\begin{array}{l}0,0247 \\
(2,02)^{* *}\end{array}$ \\
\hline $\begin{array}{l}\text { Observações } \\
\text { Teste mult. Lagrange }\end{array}$ & $\begin{array}{c}5.266 \\
4.179,44\end{array}$ & & \\
\hline
\end{tabular}

Obs: Testes t estão entre parênteses abaixo dos efeitos marginais.

*** Denota significância ao nível de $1 \%$

${ }^{* *}$ Denota significância ao nível de $5 \%$

* Denota significância ao nível de $10 \%$ 


\section{CONCLUSÕES}

O exame dos dados da Pesquisa Nacional por Amostra de Domicílios de 1998 (PNAD) revelou vários aspectos interessantes sobre a participação dos jovens no mercado de trabalho e sua escolaridade.

A presente análise mostrou a grande importância dos jovens na formação da população economicamente ativa do Brasil, especialmente para os homens e nas áreas rurais. Nas áreas urbanas 71,8\% dos homens e 50,3\% das mulheres, de 15 a 24 anos de idade, trabalhavam em 1998. Nas áreas rurais essas porcentagens foram de $87 \%$ e $51 \%$, para homens e mulheres, respectivamente. As maiores taxas de atividade para os jovens foram encontradas nas regiões mais desenvolvidas do país (Sul, Centro-Oeste e Sudeste), indicando que a atividade dos jovens está relacionada à atratividade do mercado de trabalho, ou seja, melhores salários e melhores condições de trabalho.

A inserção dos jovens no mercado de trabalho se dá de forma bastante desfavorável e, da forma que se dá, em geral, prejudica a escolaridade da maioria destes indivíduos. Os jovens brasileiros ingressam muito cedo no mercado de trabalho, nas áreas rurais cerca de $75 \%$ teve seu primeiro trabalho com 12 anos ou menos, pior ainda, cerca de $25 \%$ começou a trabalhar com menos de 10 anos. Nas áreas urbanas a entrada do jovem no mercado de trabalho se dá um pouco mais tarde, cerca de $25 \%$ dos jovens teve seu primeiro trabalho com menos de 13 anos. Essa realidade impacta negativamente na escolaridade destes indivíduos, a maioria estuda em escolas notumas, têm baixo rendimento e à vezes não conseguem completar os estudos ou o fazem com atraso. Ademais, estes jovens possuem cerca de metade da escolaridade daqueles que começaram a trabalhar depois de completar 18 anos. 
Outro aspecto relevante encontrado diz respeito à jornada de trabalho daqueles que têm emprego. A média de horas trabalhadas pelos jovens, 40 horas semanais, não é muito diferente da média encontrada para os adultos (43 horas semanais). Esse quadro demonstra as dificuldades desses jovens trabalhadores que, ao mesmo tempo em que trabalham oito horas, ainda encontram forças para freqüentar os bancos escolares, objetivando melhores oportunidades de emprego no futuro.

Apesar de exercerem jornadas de trabalho tão extensas quanto os adultos e, freqüentemente, cumprirem funções semelhantes, seus rendimentos são baixos, recebem, em média, cerca de $40 \%$ (jovens de 15 a 19 anos) e $60 \%$ (jovens de 20 a 24 anos) dos rendimentos dos adultos. Ademais, há uma proporção elevada de jovens recebendo menos que o salário estabelecido legalmente, alcançando $52 \%$ na área rural e $21 \%$ na área urbana. Há, também, uma alta porcentagem de jovens que não auferia nenhum rendimento pelo seu trabalho, cerca de $15 \%$ dos jovens trabalhadores, de 15 a 19 anos de idade, das áreas urbanas e $60 \%$ das áreas rurais não auferiam nenhum rendimento em 1998. Na faixa etária dos 20 aos 24 anos essas porcentagens alcançaram 5\% e 40\%, nas áreas urbanas e rurais, respectivamente.

Foi observada nas escolas maior porcentagem de jovens que não trabalhava comparada à que trabalhava, mas na verdade, as porcentagens de jovens que freqüentavam as escolas em diferentes idades eram baixas para ambos os grupos. Dos jovens de 15 a 17 anos que não trabalhavam, em 1998, cerca de $80 \%$ freqüentava a escola, para os jovens trabalhadores essa porcentagem caía para $65 \%$. A partir dos 18 anos a freqüência à escola decresce acentuadamente. Aos 20 anos apenas $30 \%$ e $40 \%$ dos jovens, trabalhadores e não trabalhadores, respectivamente, freqüentavam a escola. Aos 24 anos essas porcentagens eram, respectivamente, $13 \%$ e $18 \%$.

A diferença de número de anos de escolaridade completados entre os jovens que trabalhavam e os que não trabalhavam foi próximo de um ano para os jovens de 15 a 18 anos e praticamente inexistente para os jovens de 19 a 22 anos. Foi interessante observar que os jovens trabalhadores de 23 e 24 anos apresentaram, em média, sete 
meses a mais de escolaridade em relação aos não trabalhadores. Isso pode estar indicando que, se por um lado, o trabalho provoca atraso na escola para os mais jovens, para aqueles com mais idade, o trabalho proporciona maior acesso ao sistema de ensino, tendo em vista que o estudo requer recursos financeiros e o trabalho proporciona tal aporte.

Embora o perfil educacional dos jovens tenha melhorado, esse indicador ainda é baixo. A escolaridade média dos jovens brasileiros era, em 1998, de 6,7 anos. Mais da metade, $55,4 \%$, não tinha sequer completado o ensino fundamental e $17,5 \%$ não conseguiu nem ao menos terminar a escola primária. $O$ mais grave é que $5,6 \%$ dos jovens não tinha instrução alguma ou tinha menos de um ano de estudo.

Outro problema enfrentado pelos jovens diz respeito à forma de contratação, onde a grande maioria deles trabalha no mercado de trabalho informal (65\%), neste mercado, em geral, os salários pagos são mais baixos e as condições de trabalho são mais precárias, sem direitos trabalhistas e sem as proteções sociais básicas - saúde, previdência e capacitação profissional e onde ocorrem as maiores taxas de rotatividade.

A forma de inserção do jovem no mercado de trabalho e sua escolaridade estão fortemente associada à grande desigualdade na distribuição de renda no país. A renda média mensal per capita dos domicílios dos jovens que não trabalhavam era cerca de $50 \%$ e $25 \%$ maior do que nas famílias com jovens trabalhando, para as faixas etárias de 15 a 19 e 20 a 24 anos, respectivamente. Por outro lado, quanto maior o rendimento familiar mensal per capita, maior o percentual de jovens que só se dedicam ao estudo e menor o daqueles que se dedicam apenas ao trabalho. A porcentagem dos jovens que só estudava, em 1998, com renda mensal per capita maior que um salário mínimo (42\%) era mais que o dobro da porcentagem dos jovens que só estudava com renda mensal de até meio salário mínimo per capita (18\%). Ademais, a porcentagem de jovens que só trabalhava com renda mensal per capita de até meio salário mínimo $(41 \%)$ era quase o dobro da porcentagem dos jovens que só rabalhava com renda mensal per capita maior que um salário mínimo (23\%). 
O principal motivo observado para os jovens trabalharem é para complementar a renda familiar. Verificou-se que apesar de seus baixos rendimentos, a contribuição dos jovens no rendimento familiar foi muito significativa. A contribuição dos jovens de 15 a 19 anos, no rendimento familiar, foi de mais de $30 \%$ em $45 \%$ dos domicílios urbanos e em 55\% dos domicílios rurais. Essas mesmas porcentagens para os jovens de 20 a 24 anos foram de $68 \%$ e $75 \%$, respectivamente. Os jovens de 15 a 19 anos contribuem com mais de $50 \%$ da renda familiar em $20 \%$ das famílias. Já a contribuição dos jovens de 20 a 24 anos com mais de $50 \%$ da renda familiar se dá em mais de $40 \%$ das famílias.

Os resultados dos modelos lógite multinomial analisando a probabilidade de o jovem trabalhar, frequientar escola e cuidar de afazeres domésticos, indicaram que quanto mais avançada a idade do jovem, menor é a probabilidade de estudar, independente de trabalhar ou não, e maior a probabilidade de só trabalhar.

Quanto maior o grau de instrução dos chefes de família menor é a probabilidade de os jovens só trabalharem e, se trabalham, maior é a sua probabilidade de, também, freqüentarem a escola. Desta forma, a presença no âmbito doméstico de um responsável com maior escolaridade, funciona como fator de ampliação das oportunidades e de sucesso educacional da população jovem. Assim, a baixa escolaridade da população adulta brasileira representa um grande obstáculo para o avanço do nível educacional do país. Pais que não tiveram nenhuma ou insuficiente educação dão pouca importância à escola, prejudicando a educação formal de seus filhos e dificultando as políticas públicas educacionais. Por outro lado, indivíduos com mais anos de estudo são mais cientes de seus direitos e criam filhos mais educados e saudáveis, diminuindo a pobreza, a exploração e os abusos a longo prazo. Desta forma, faz-se necessário políticas de conscientização voltada para todos os pais, mostrando-lhes os benefícios da educação de seus filhos e criando uma cultura no país de que crianças e jovens devem estar na escola para que tenham um futuro melhor. 
A idade do chefe de família diminui a probabilidade de os jovens só trabalharem, e aumenta a probabilidade das demais alternativas, indicando que chefes mais velhos são capazes de oferecer melhores condições de estudo aos seus jovens.

O tamanho do domicílio também afetou a freqüência à escola e o trabalho dos jovens. O número de crianças na família teve efeito negativo na escolaridade de todos os jovens. Tais resultados devem se dar em razão da necessidade de complementação da renda familiar, forçando os jovens a se dedicarem mais ao trabalho ou às atividades domésticas e menos ao estudo. Deste modo, pode-se dizer que a tendência de queda da taxa de natalidade no Brasil pode ser benéfica para a escolarização de sua população. Assim, políticas de controle populacional deveriam entrar na agenda de medidas públicas a serem tomadas com vistas a melhorar o nível geral de escolarização da população brasileira e conseqüentemente seu bem estar. Por outro lado, o aumento de pessoas com oito ou mais anos de idade diminui a probabilidade de os jovens terem que se dedicar exclusivamente ao trabalho, permitindolhes assim acesso ao estudo.

A renda familiar no Brasil demonstra as desigualdades de acesso ao sistema de ensino e a permanência no mesmo. Os resultados obtidos para a variável renda familiar per capita indicaram que em famílias mais ricas há maior probabilidade de o jovem freqüentar escola e menor probabilidade de os jovens só trabalharem e não estudarem nem trabalharem. Tal associação aponta para uma relação perversa entre renda e formação educacional, em que as maiores chances são reservadas aos jovens que dispõem de melhor condição. Desse modo, as carências sociais no âmbito da família se reproduzem e recaem sobre os jovens. O processo educacional ao se estruturar sobre estas carências pouco contribui no sentido de neutralizá-las diante da oportunidade de promover a formação e transmissão de conhecimento básico e comum a todos os jovens.

O maior problema enfrentado pelos jovens brasileiros, como na maior parte do mundo, são as altas taxas de desemprego. Em 1998 existiam mais de 3,3 milhões de jovens desempregados, representando $17,2 \%$ do total de jovens ativos no país, sendo 
esta, portanto, mais que o dobro da taxa de desemprego dos adultos. As taxas de desemprego são mais altas para as mulheres, para os mais jovens e nas áreas urbanas. Para os homens jovens, em 1998, era de 16,8\% e 4,4\%, nas áreas urbanas e rurais, respectivamente. Para as mulheres jovens, as taxas de desemprego foram ainda maiores, 25,2\% nas áreas urbanas e 9,4\% nas áreas rurais. Ademais, entre as maiores dificuldades para se obter emprego está a idade, o grau de escolaridade e a experiência.

Os resultados da análise da condição de atividade dos jovens brasileiros, a partir do modelo lógite multinomial, indicaram que as variáveis explanatórias usadas na análise têm impacto diferenciado em suas probabilidades de inatividade, emprego e desemprego. Os resultados que mais interessam dizem respeito às probabilidades de desemprego, visto ser este um dos mais graves problemas enfrentados pelos jovens. As altas taxas de desemprego enfrentadas pelos jovens traz consequiências sérias para os jovens e suas famílias, as quais muitas vezes são irreversíveis. O modelo mostrou que as probabilidades de desemprego são crescentes com anos de escolaridade para homens residentes nas áreas rurais e para todas as mulheres. $\mathrm{O}$ aumento na probabilidade de desemprego com incrementos na escolaridade é, a princípio, um fenômeno de difícil explicação. Isso pode se dar pelo fato da escolaridade diminuir a taxa de inatividade dos jovens, aumentando assim, a procura por vagas de trabalho, o que pode provocar aumento nas taxas de desemprego para este segmento populacional. Por outro lado, o grau de seletividade na busca por trabalho pode aumentar com os anos de escolaridade, o que deve elevar a duração do desemprego e, portanto, a probabilidade de desemprego. Ademais, na média, os jovens que ainda freqüentam a escola possuem mais escolaridade (7,4 anos) que os demais (6,1 anos), o que conjugado com sua maior probabilidade de desemprego indica que o espaço no mercado de trabalho para os estudantes deve ser mais estreito, tendo em vista que estes possuem restrição de tempo para dedicação exclusiva ao trabalho. Assim, pode-se dizer que apesar da extrema importância da escolaridade na vida profissional dos indivíduos, ela não é garantia de emprego para os jovens. 
A probabilidade de desemprego é decrescente com a experiência do jovem no mercado de trabalho. Isso era esperado, uma vez que o aumento de experiência aumenta a produtividade dos trabalhadores. Constatou-se que o efeito da experiência sobre a probabilidade de desemprego é bem mais forte que o efeito da escolaridade, indicando que para os jovens de 15 a 24 anos de idade o mercado de trabalho valoriza mais a experiência do que a escolaridade e/ou que a experiência nesta faixa etária é um grande diferencial. Visto que a falta de experiência no mundo do trabalho é inerente à juventude aqueles que possuem alguma experiência estão em situação de vantagem em relação aos demais.

Os jovens negros possuem probabilidades maiores de desemprego em relação aos brancos e pardos, mesmo controlando outras características (como escolaridade, região de residência, experiência, etc.) que podem também afetar essa probabilidade. Há, portanto, fortes indícios de existência de discriminação racial contra os negros no preenchimento das vagas de trabalho existentes no mercado.

A renda familiar per capita afeta negativamente a probabilidade de desemprego dos jovens. Tal resultado pode ser reflexo do efeito do salário reserva, para os quais o suporte financeiro por parte da família lhes permite postergar a entrada no mercado de trabalho, o que aumenta a taxa de inatividade e, portanto, diminui o congestionamento da busca por trabalho por este segmento da população, diminuindo assim, sua probabilidade de 'desemprego. Por outro lado, quanto maior é o suporte financeiro do jovem por parte da família, maiores são as condições de formação e preparo para o mercado de trabalho, o que aumenta o seu grau de empregabilidade, bem como, maiores são as condições de o jovem tornar-se trabalhador autônomo abrindo negócio próprio, sendo este o caminho encontrado por muitos indivíduos para fugir do desemprego. Ademais, indivíduos mais ricos relacionam-se com pessoas mais ricas e, portanto, possuem melhores contatos para conseguir emprego.

De forma sucinta pode-se dizer, então, que os jovens enfrentam graves problemas em termos de dificuldades de conciliação do estudo com o trabalho, baixos 
níveis de escolaridade, altas taxas de desemprego, relações de contratação precárias, jornadas extensas de rabalho e baixos rendimentos. Tal realidade tem fortes implicações para o mercado de trabalho e para a sociedade.

Milhões de jovens brasileiros estão cercados por um ambiente desanimador, sem perspectivas de uma boa escolaridade e muito menos de um bom emprego e consequentemente de melhora de vida. Sem esta possibilidade, muitos encaram a vida como sendo uma perspectiva sombria. Os baixos níveis de escolaridade e o alto desemprego contribui para o aumento da exclusão e da pobreza. Isto contribui para a perda de valorosa contribuição para o crescimento econômico de um dos grupos mais produtivos da sociedade, retarda o movimento dos jovens para a vida adulta e se torna a maior causa do uso de drogas e práticas criminais, podendo levar à alienação da sociedade. O Brasil necessita de uma política para a juventude que compreenda educação, trabalho, cultura, saúde e lazer, de modo a garantir melhorias na qualidade de vida de seus jovens e criar condições para o desenvolvimento sustentado do país.

Do ponto de vista econômico, há evidências de que a educação contribui significativamente para elevar a produtividade dos trabalhadores e consequentemente contribui para o desenvolvimento do país. Foi constatado que os jovens trabalhadores, principalmente os mais pobres, têm mais dificuldades de investir em sua educação, os quais possuem as menores taxas de freqüência à escola e consequentemente menores níveis de escolaridade. Isso compromete o futuro desses jovens, os quais devem reproduzir as condições sociais vigentes, onde os mais pobres têm menos escolaridade e trabalham mais, perpetuando o ciclo da pobreza.

A educação é uma das poucas portas que a sociedade contemporânea abre para a mobilidade social. Pode-se dizer que se o sistema educacional não encontrou mecanismos adequados para reter esses jovens, mecanismos sociais externos, determinados em grande medida pela premência de atender as necessidades imediatas e de garantir um padrão de vida, concorreriam para afastá-los do mercado. Assim, dentre as políticas para minorar o desemprego dos jovens destaca-se os programas de treinamento e sua manutenção por mais tempo no sistema de ensino, como forma de 
melhorar sua auto-estima e suas condições de empregabilidade atuais e futuras, diminuindo o problema atual e futuro das novas gerações do país. O país não pode deixar que a educação seja atividade secundária para os jovens e, muito menos que seja abandonada por questões de sobrevivência. Para tanto é necessária provisão pública de educação básica, estruturação e adequação do ensino às demandas sociais e econômicas de cada região, além de políticas macroeconômicas que viabilizem condições de acesso e permanência dos mais pobres ao sistema de ensino.

Neste sentido, a adoção de programas que garantam a permanência dos jovens na escola ou que permitam conciliar formação escolar e formação profissional pode se transformar em um mecanismo capaz, no futuro, de uma inserção mais favorável no mercado de trabalho. Isso, além de depender de maneira mais direta do dinamismo na geração de postos de trabalho, exige a implementação de políticas que viabilizem a continuidade da formação educacional, que respeite o maior comprometimento dos jovens com o mundo do trabalho e sua maior dificuldade de conciliar as duas atividades. Ademais, a redução da jornada de trabalho para quem estuda e trabalha como alternativa para preservar a formação, valorizando a educação como integradora da base de desenvolvimento. Essa proposta poderia ser acompanhada para a discussão de redução da jornada de trabalho para os demais trabalhadores, visto que, a jornada de trabalho brasileira é muito longa quando comparada com a maioria dos países em grau semelhante de desenvolvimento.

Deve-se, também, estudar a possibilidade de criação de programas de reciclagem da mão-de-obra que está desempregada, vinculado ao seguro desemprego. Essa seria uma forma bastante eficaz de atingir diretamente aqueles indivíduos que estão em situação crítica. Entretanto, este programa não atingiria aqueles que procuram pelo primeiro emprego. Portanto é necessário também transformar projetos de extensão e pesquisas universitárias em programas integrados à realidade brasileira e regulamentar estágios obrigatórios nas unidades de ensino universitário e de formação técnica. Os estágios devem servir realmente como obtenção de experiência e preparação profissional para o ingresso do jovem no mercado de trabalho, e não como subemprego. 
Outra política que poderia ser eficaz no combate ao desemprego dos jovens seria renúncias fiscais para a contratação de empresas juniors, de modo a quebrar a antiga corrente formada pelas empresas, que muitas vezes recuam na contratação de recém formados alegando falta de experiência

Outra importante medida que deve ser tomada é o desenvolvimento de programas para a geração de empregos para os jovens com a participação de empresa do setor privado em parceria com o governo e instituições não governamentais. Ampliação dos serviços prestados pelo SENAI e SENAC - Serviço Nacional de Aprendizagem Industrial e Comercial, bem como, do SEBRAE - Serviço Brasileiro de Apoio às Micro e Pequenas Empresas.

Ademais, a mudança da situação do desemprego juvenil só será possível com uma estratégia de distribuição de renda, a qual permitiria o desenvolvimento social e o crescimento econômico. Cerca de 50 milhões de brasileiros - $34 \%$ da população, estão abaixo da linha de pobreza, ou seja, não possuem o mínimo necessário para cobrir os gastos com a cesta alimentar, vestuário, habitação e transportes. A principal causa desta triste realidade é a grande desigualdade da distribuição de renda no país, uma das piores do mundo, onde os $50 \%$ mais pobres detêm apenas 13\% dos rendimentos enquanto o $1 \%$ mais rico se apropria de cerca de $14 \%$.

Grande parte das pessoas que hoje estão no mercado de trabalho não precisaria fazer parte deste, se houvesse uma política social mais justa e mais igualitária. Segundo Pochmann (1999) 2,8 milhões de menores de 14 anos estão no mercado de trabalho, no país 5,2 milhões de aposentados e pensionistas são obrigados a se manter na ativa para complementar a renda mensal, 3,2 milhões de brasileiros têm dois ou mais empregos e ainda, 26 milhões faz horas extras, tirando 2,4 milhões de postos de trabalho. Essas pessoas, não por culpa delas, mas devido à injustiça social no país, acabam acirrando a disputa por uma vaga no mercado de trabalho, piorando sobremaneira a situação dos jovens no país. 
Assim, o combate à pobreza tiraria do mercado grande parte desse excedente de mão-de-obra. Nesse sentido, medidas efetivas e sustentáveis de combate à pobreza devem, ao lado de ações emergenciais e políticas compensatórias, examinar e intervir sobre os mecanismos de produção e reprodução da pobreza. No caso da economia brasileira, não há como discutir seriamente o combate à pobreza sem enfrentar o problema da desigualdade de renda, patrimônio, capacidades e acesso aos recursos e políticas públicas, o que implica mudanças importantes na estrutura tributária e no perfil do investimento social, que associe mecanismos como renda mínima e bolsas escolas, entre outras, para as famílias carentes, de modo a assegurar melhores condições de acesso e manutenção no sistema de ensino.

No Brasil a estrutura tributária tem um caráter fortemente regressivo. Portanto, uma reforma tributária comprometida com a equidade deveria levar em conta os impactos distributivos da renda e rever questões relativas ao imposto de renda, patrimônio e propriedades, bem como, os impostos indiretos que recaem sobre os consumidores e a pesada carga tributária sobre as pequenas e micro empresas que são responsáveis pela maior parte das oportunidades de emprego para os jovens.

Os jovens precisam entrar na agenda pública nacional com prioridade. Necessitam de uma oferta variada de programas formativos, inovadores e ambiciosos, que forneçam as bases para uma efetiva inclusão social e melhores chances de inserção no mundo do trabalho.

Para aumentar a igualdade de renda e a mobilidade social é fundamental o investimento contínuo na expansão da educação que priorize não somente as crianças, mas, também, dê especial atenção aos jovens brasileiros, garantido-lhes ao menos o ensino médio. Para tanto, é imprescindível haver um número adequado de escolas disponíveis e custos com materiais, uniformes, transportes, etc. acessíveis ou subsidiados, para garantir que os jovens de famílias pobres não abandonem os bancos escolares. 
Como trabalhos futuros fica a sugestão de avaliar os programas existentes voltados para os jovens quanto à sua eficácia e abrangência, de modo a possibilitar sugestões de políticas específicas para os formuladores de leis com base em evidências empíricas fortes. Sugere-se, também, estudar a inserção dos jovens no mercado de trabalho por tipos de ocupações para verificar setores com maior potencial de criação de empregos para os jovens, de modo a direcionar os esforços das políticas de emprego para este grupo da população. Além disso, seria interessante realizar a análise feita no presente trabalho, apenas para os jovens de classe de renda baixa, visto que se observou que são estes que mais precisam trabalhar e, entretanto, enfrentam as maiores dificuldades de inserção no mercado de trabalho. 


\section{REFRÊNCIAS BIBLIOGRÁFICAS}

AMADEO, E. Mercado de trabalho brasileiro: rumos, desafios e o papel do Ministério do Trabalho. http://www.mtb.gov.br. (17/05/2000).

BANCO MUNDIAL. World Development Indicators. http://www.worldbank.org. (27/09/2001).

BARRET, A; CALLAN, T.; NOLAN, B. Returns do education in the Irish youth labour market. Journal of population economics, v.12, p.313-326, Spring 1999.

BARROS, R. P.; MENDONÇA, R. S. P. Infância e adolescência no Brasil: as consequiências da pobreza diferenciadas por gênero, faixa etária e região de residência. Pesquisa e Planejamento Econômico, v.21, n. 2, p.355-376, ago. 1991.

BARROS, R. P.; MENDONÇA, R. S. P. Determinantes da participação de menores na força de trabalho. Rio de Janeiro: IPEA, 1990. 16p. (Texto para Discussão, 200)

BARROS, R. P.; CAMARGO, J. M.; MENDONÇA, R. S. P. Estrutura do desemprego no Brasil. Rio de Janeiro: IPEA, 1997. 31p. (Texto para discussão, 478)

BARROS, R. P.; MENDONÇA, R. S. P.; DELIBERALLI, P. P.; BAHIA, M. O trabalho infanto-juvenil no Brasil. In: SEMINÁRIO PARA ELABORAÇÃO DE ESTRATÉGIAS PARA COMBATER O TRABALHO INFANTIL NO SERVIÇO DOMÉSTICO. São Paulo, 2000. Estratégias para Combater o Trabalho Infantil no Serviço Doméstico: São Paulo: IPEA, 2000.

BLAU, F. D.; KAHN, L. M. Gender and youth employment outcomes: the US and West Germany, 1984-91. Cambridge: NBER, 1997.(Working paper series, 6078)

BLOOM, D. E.; FREEMAN, R. B; KORENMAN, S. D. The labour-market consequences of generational crowding. European Journal of Population, v.3, p.131-176, 1987. 
CAMARANO, A A .Jovens Brasileiros: já independentes? Como Vai? População Brasileira, v.6, n.1, p.1-13, mar. 2000.

CANUTO, O. Desnaturalizando a desigualdade de renda brasileira. Valor Econômico. São Paulo, 19 dez. 2000a. http://www.eco.unicamp.br/artigos/artigo150.htm (27/09/20011).

CARNICHAL, F.; WARD, R. Youth unemployment and crime in the english regions and wales. Aplied Economics, v 32, p.559, Apr. 2000.

CARD, D. LEMIEUX, T. Adapting to circunstances: the evolution of work, school, and living arrangements among north american youth. Cambridge: NBER, 1997.(Working paper series, 6142)

COURSEUIL, C. H.; REIS, C.; URANI, A. Determinantes da estrutura do desemprego no Brasil; 1986-1995. In: XXIV ENCONTRO NACIONAL DE ECONOMIA. Campinas, 1996. Anais. Rio de Janeiro: ANPEC, 1996. p.462-477.

COURSEUIL, C. H,; SANTOS, D. D.; FOGUEL, M. N. Decisões críticas em idades críticas: a escolha dos jovens entre estudo e trabalho no Brasil e em outros países da América Latina. Rio de Janeiro: IPEA, 2001. 51p. (Texto para Discussão, 797)

DUSTMANN, C.; RAJAH, N.; SMTTH, S. Teenage truancy, part-time working and wages. Population Economics, v.10, n.4, p.425-442, Spring 1997.

FERNANDES, R. Mercado de trabalho não-regulamentado: participação relativa e diferenciais de salários. Pesquisa e Planejamento Econômico, v.26, n.3, p.417-442, dez. 1996

FERNANDES, R.; PICCHETTI, P. Uma análise da estrutura do desemprego e da inatividade no Brasil metropolitano. Pesquisa e Planejamento Econômico, v.29, n.1, p.87-111, abr. 1999. 
FREEMAN, R. Why do so many young american men commit crimes and what might we do about it? Journal of economic perspectives, v.10, n.1, p.25-42, Winter 1996.

FREEMAN, R; RODGERS, W. M. Area economic conditions and the labor market outcomes of young men in the 1990s expansion. Cambridge: NBER, 1999. 45p. (Working paper series, 7073)

FREEMAN, R. B. The effect of demographic factors on age-earnings profiles. The Journal of Human Resource, v.14, p.289-318, 1979.

FREEMAN, R.B.; HOLZER, H. J. Black youth employment crisis. Chicago: University of Chicago Press, 1986. 480P.

FUNDAÇÃO INSTITUTO BRASILEIRO DE GEOGRAFIA E ESTATÍSTICA. Pesquisa Nacional por Amostra de Domicílios. (Compact dis). Rio de Janeiro: IBGE, 1998.

GOIS, A. Provão revela barreira racial no ensino. Folha de São Paulo. São Paulo, 14 jan. 2001, p.C8.

GOLDSMITH, A. H., VEUM, J. R., DARITY, W. J. The impact of labor force history on self-steem and its component parts, anxiety, alienation and depression. Journal of Economic Psychology, v.17, p.183-220, 1996.

GREENE, W. Econometric analysis. 3. ed. New Jersey: Prentice Hall, 1997. 1075p.

GREENE, W. LIMDEP version 7.0. New York: Econometric software Inc., 1995. $850 \mathrm{p}$.

GROOTAERT, C.; KANBUR, R. Child labour: an economic perspective. International Labour Review, v.134, n.2, p.187-203, 1995. 
GROOTAERT, C.; PATRINOS, H. A. The policy analysis of child labor: a comparative study. Washington: World Bank, Jan. 1998. 245p.

JENSEN, P.; H. NIELSEN. Child labour or school attendance? Evidence from Zambia." Journal of Population Economics, v.10, n.4, p.407-424, 1997.

KASSOUF, A. L.. Wage gender discrimination and segmentation in the brasilian labor market. Economia Aplicada, v.2, n.2, p. 243-269, June 1998.

KASSOUF, A L. O trabalho infantil no Brasil. Piracicaba, 1999. 110 p. Tese de Livre Docência. - Escola Superior de Agricultura "Luiz de Queiroz", Universidade de São Paulo.

KASSOUF, A L.; MCKEE, M; MOSSIALOS, E. Early entrance to the job market and its effect on adult health: evidence from Brasil. Healthy Policy and Planning, v. 16, n. 1, p. 21-28, Mar. 2001.

KORENMAN, S; NEWMARK, D. Cohort crowding and youth labor markets: a cross national analisys. Cambridge: NBER, 1997.71p. (Working paper series, 6031)

LEME, M. C. S.; WAJNMAN, S. Só estudar, só trabalhar, fazer ambas as coisas ou não fazer nenhuma delas? A decisão de alocação de tempo dos adolescentes brasileiros. In: Adolescents in Latin America and Caribbean: examining time allocation decisions with cross-country micro-data. São Paulo: Universidade de São Paulo, 2000.

LYNCH, L. M. The youth labor market in the eighties: determinants of re-employment probabilities for young men and woman. The Review of Economics and Statistics, v.71, n.1, p.37-45, Feb. 1989.

LYNCH, L. M. State dependency in youth unemployment: a lost generation? Journal of Econometrics, v.28, p.71-84, Apr. 1985. 
MADALLA, G. Limited-dependent and qualitative variables in econometrics. Cambridge: Cambridge Universit Press, 1990. 401p.

MARCOUILLER, D.; CASTILA, V. R.; WOODRUFF, C. Formal measures of the informal-sector wage gap in Mexico, El Salvador and Peru. Economic Development and Cultural Change, v.45, n.2, p.367-392, Jan. 1997.

MCFADEN, D. Conditional logit analisys of qualitative choice behavior. In ZAREMBKA, P. (ed.). Frontiers in econometrics. New York: Academic Press, 1973. 252p.

MENEZES-FILHO, N.; FERNANDES, R.; PICHETTI, P.; NARITA, R. Explaining the time allocation decisions of adolescents in Latin America and Caribbean. São Paulo: Universidade de São Paulo, 2000. 41p. (Relatório desenvolvido no âmbito da $8^{\mathrm{a}}$ Ronda do Banco Interamericano de Desenvolvimento - BID).

MORREL, S. L; TAYLOR, R. J.; QUINE, S.; KERR, C. B; WESTERN, J. A casecontrol study of employment status and mortality in a cohort of Australian youth. Social Science \& Medicine, v.49, p.383-392, 1999.

MORREL, S. L; TAYLOR, R. J.; KERR, C. B. Unemployment and young people's health. Medical Journal of Austália, v.168, n.5, p.236-240, 1998.

ORGANIZAÇÃO INTERNACIONAL DO TRABALHO (OIT). Employing youth: promoting employment - intensive growth. Paper for the symposium on strategies to combat youth employment). http://www.ilo.org. (17/05/2000).

OIT - FÓRUM NACIONAL JOVEM SÉCULO XXI. 1., Brasília, 1999. Educação, Formação profissional \& empregabilidade. Brasília: OIT, 1999. 26p.

PERO, V. L. A carteira de trabalho no mercado de trabalho metropolitano brasileiro. Revista de Estudos Sociais e Econômicos, v.1, p.159-196, 1994. 
POCHMANN, M. A inserção ocupacional e o emprego dos jovens. São Paulo: ABET, 1998. 104p.

POCHMANN, M. Queda de renda impede redução do desemprego. O Estado de São Paulo. São Paulo, 5 jul. 1999, p. B1.

POCHMANN, M. Desemprego: mazela da globalização. São Paulo, 15 fev. 2000. http://www.feaac.org.br/informações/globalização (01/10/2001).

PROGRAMA DAS NAÇÕES UNIDAS PARA O DESENVOLVIMENTO (PNUD). Relatório sobre o desenvolvimento humano no Brasil. Rio de Janeiro: IPEA Brasília: PNUD, 1996. 185p.

ROCHA, S. Pobreza e desigualdade no Brasil: esgotamento dos efeitos distributivos do plano real. Rio de Janeiro: IPEA, 2000. 26p. (Texto para Discussão, 721)

SENAUER, B.; GARCIA, M.; JACINTO, E. Determinants of the intrahousehold allocation of food in the rural Philippines. American Journal of Agricultural Economics, v.70, n.1 ,p.170-180, 1988.

SILVA, N. D. V. Mercados de trabalho formal e informal: uma análise da discriminação e da segmentação. Piracicaba, 1997. 147 p. Dissertação (Mestrado). Escola Superior de Agricultura "Luiz de Queiroz", Universidade de São Paulo.

SWAMINATHAN, M. Do child workers acquire specialised skills? A case study of teenage workers in Bhavnagar. The Indian Journal of Labour Economics, v.40, n.4, p.829-839,1997.

TIEFENTHALER, J. Female labor force participation and wage determination in Brazil, 1989. In: PSACHAROPOULOS, G.; TZANNATOS, Z. (Eds.) Cases studies on women's employment and pay in Latin America, Washington: World Bank, 1994. 
URANI, A. Ajuste macroeconômico e flexibilidade do mercado de trabalho no Brasil - 1981/95. . Rio de Janeiro: IPEA, 1996. 58p. (Texto para Discussão, 380)

ZYLBERSTAJN, H.; PAGOTTO, C. S.; PASTORE, J. A mulher e o menor na força de trabalho. São Paulo: Nobel; Brasília: Ministério do Trabalho, 1985. 168p.

WADSWORTH, M. E. J., MONTGOMERY, S. M., BARTLEY, M. J. The persisting of unemployment on health and social well-being in men early in working life. Social Science \& Medicine, v. 48, p. 1491-1499, 1999. 
APÊNDICES 
Tabela A1. Equações de inatividade e desemprego para homens jovens, nas áreas urbanas e rurais (modelo próbite binomial). A variável dependente é 1 se o jovem é inativo ou desempregado e 0 se o jovem é ativo ou empregado.

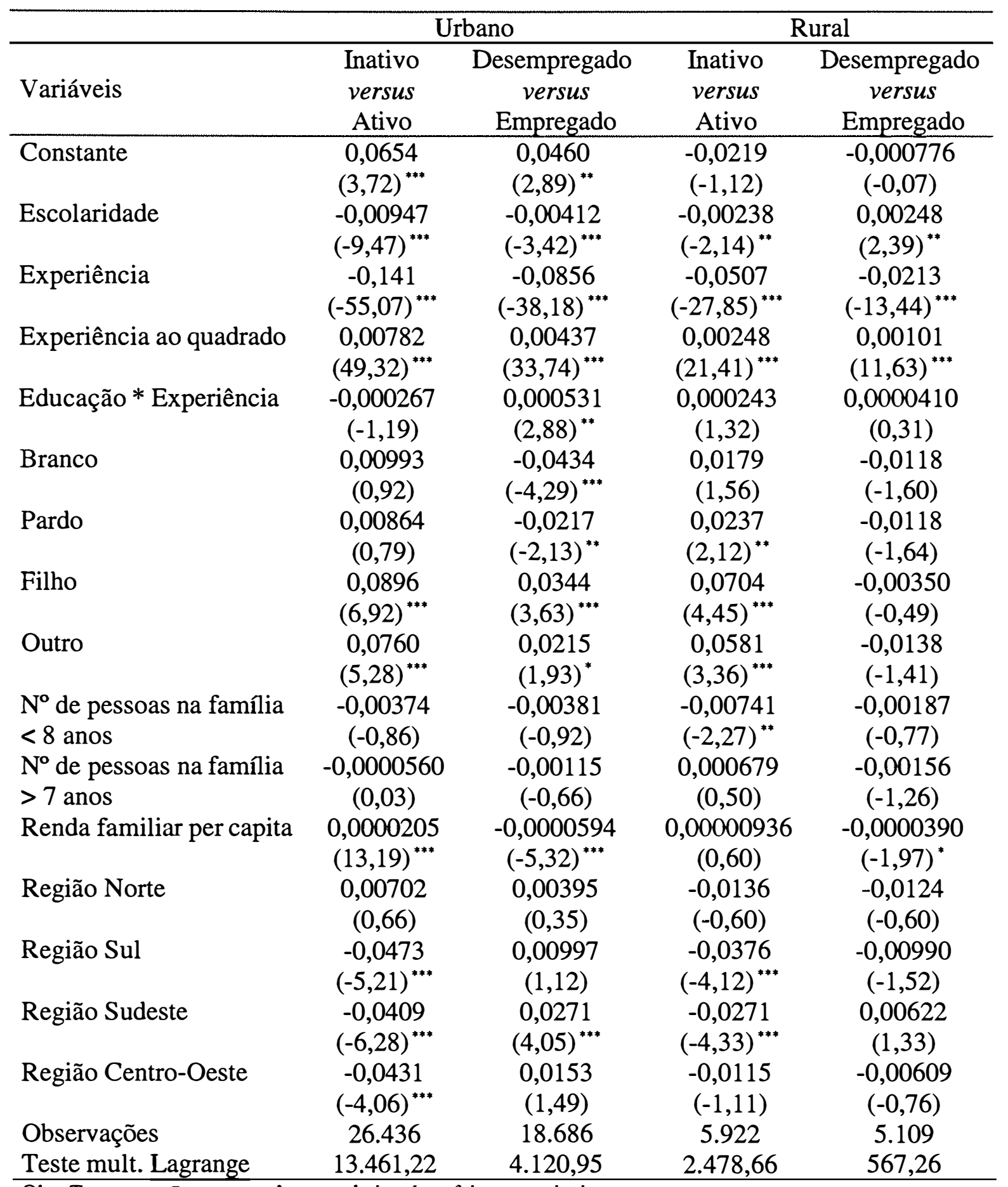

Obs: Testes $t$ estão entre parênteses abaixo dos efeitos marginais.

*** Denota significância ao nível de $1 \%$

${ }^{* *}$ Denota significância ao nível de $5 \%$

*Denota significância ao nível de $10 \%$ 
Tabela A2. Equações de inatividade e desemprego para mulheres jovens, nas áreas urbanas e rurais (modelo próbite binomial). A variável dependente é 1 se o jovem é inativo ou desempregado e 0 se o jovem é ativo ou empregado.

\begin{tabular}{|c|c|c|c|c|}
\hline \multirow[b]{2}{*}{ Variáveis } & \multicolumn{2}{|c|}{ Urbano } & \multicolumn{2}{|c|}{ Rural } \\
\hline & $\begin{array}{l}\text { Inativo } \\
\text { versus } \\
\text { Ativo }\end{array}$ & $\begin{array}{c}\text { Desempregado } \\
\text { versus } \\
\text { Empregado }\end{array}$ & $\begin{array}{c}\text { Inativo } \\
\text { versus } \\
\text { Ativo }\end{array}$ & $\begin{array}{c}\text { Desempregado } \\
\text { versus } \\
\text { Empregado }\end{array}$ \\
\hline Constante & $\begin{array}{c}0,419 \\
(17,95)^{* \cdots}\end{array}$ & $\begin{array}{c}0,250 \\
(10,41)^{\cdots \cdots}\end{array}$ & $\begin{array}{c}0,642 \\
(10,13)^{* * *}\end{array}$ & $\begin{array}{l}0,0300 \\
(1,18)\end{array}$ \\
\hline Escolaridade & $\begin{array}{c}-0,0326 \\
(-21,98)^{* *}\end{array}$ & $\begin{array}{c}-0,0107 \\
(-6,32)^{* *}\end{array}$ & $\begin{array}{c}-0,0367 \\
(-8,76)^{\cdots *}\end{array}$ & $\begin{array}{c}0,000913 \\
(0,51)\end{array}$ \\
\hline Experiência & $\begin{array}{c}-0,227 \\
(-56,59)^{\cdots \cdots}\end{array}$ & $\begin{array}{c}-0,142 \\
(-37,72)^{* * *}\end{array}$ & $\begin{array}{c}-0,254 \\
(-34,18) \cdots \cdots\end{array}$ & $\begin{array}{c}-0,0379 \\
(-11,19)^{* * *}\end{array}$ \\
\hline Experiência ao quadrado & $\begin{array}{c}0,0125 \\
(49,29)^{* \cdots}\end{array}$ & $\begin{array}{c}0,00755 \\
(35,69)^{* \cdots}\end{array}$ & $\begin{array}{c}0,0120 \\
(24,76)^{* *}\end{array}$ & $\begin{array}{l}0,00189 \\
(9,82)^{* *}\end{array}$ \\
\hline Educação * Experiência & $\begin{array}{c}0,000709 \\
(2,17)^{* *}\end{array}$ & $\begin{array}{l}0,000999 \\
(3,39)^{* * *}\end{array}$ & $\begin{array}{l}0,00312 \\
(4,40)^{* * *}\end{array}$ & $\begin{array}{c}-0,000319 \\
(-1,04)\end{array}$ \\
\hline Branco & $\begin{array}{l}0,0658 \\
(4,18)^{* \cdots}\end{array}$ & $\begin{array}{c}-0,0671 \\
(-4,48)^{\cdots \cdots}\end{array}$ & $\begin{array}{c}0,00446 \\
(0,10)\end{array}$ & $\begin{array}{c}-0,00489 \\
(-0,27)\end{array}$ \\
\hline Pardo & $\begin{array}{l}0,0511 \\
(3,20)^{* *}\end{array}$ & $\begin{array}{l}-0,0373 \\
(-2,44)^{* *}\end{array}$ & $\begin{array}{c}0,0249 \\
(0,56)\end{array}$ & $\begin{array}{l}0,0146 \\
(0,81)\end{array}$ \\
\hline Filho & $\begin{array}{c}0,00237 \\
(0,14)\end{array}$ & $\begin{array}{r}-0,0530 \\
(-3,21) \cdots\end{array}$ & $\begin{array}{l}-0,0195 \\
(-0,40)\end{array}$ & $\begin{array}{l}-0,0487 \\
(-2,75)^{* *}\end{array}$ \\
\hline Cônjuge & $\begin{array}{c}0,176 \\
(11,65)^{\cdots \cdots}\end{array}$ & $\begin{array}{c}0,0221 \\
(1,55)\end{array}$ & $\begin{array}{r}0,112 \\
(2,69)^{*}\end{array}$ & $\begin{array}{l}-0,0322 \\
(-2,29)^{* *}\end{array}$ \\
\hline Outro & $\begin{array}{l}-0,0680 \\
(-3,52)^{* \cdots}\end{array}$ & $\begin{array}{c}-0,109 \\
(-6,03)^{* * *}\end{array}$ & $\begin{array}{l}-0,0855 \\
(-1,45)\end{array}$ & $\begin{array}{l}-0,0415 \\
(-1,95)^{* *}\end{array}$ \\
\hline $\begin{array}{l}N^{\circ} \text { de pessoas na família } \\
<8 \text { anos }\end{array}$ & $\begin{array}{c}0,0129 \\
(-2,39)^{* *}\end{array}$ & $\begin{array}{c}0,00842 \\
(1,46)\end{array}$ & $\begin{array}{c}0,00732 \\
(0,66)\end{array}$ & $\begin{array}{c}-0,00542 \\
(-1,15)\end{array}$ \\
\hline $\begin{array}{l}N^{\circ} \text { de pessoas na família } \\
>7 \text { anos }\end{array}$ & $\begin{array}{c}-0,00269 \\
(-0,96)\end{array}$ & $\begin{array}{l}-0,00838 \\
(-2,92)^{* *}\end{array}$ & $\begin{array}{c}-0,0144 \\
(-0,02)\end{array}$ & $\begin{array}{c}-0,00367 \\
(-1,33)\end{array}$ \\
\hline Renda familiar per capita & $\begin{array}{l}0,000155 \\
(13,87)^{* \cdots}\end{array}$ & $\begin{array}{c}-0,0000330 \\
(-2,57)^{* *}\end{array}$ & $\begin{array}{c}0,0000623 \\
(0,96)\end{array}$ & $\begin{array}{l}0,0000289 \\
(1,50)\end{array}$ \\
\hline Região Norte & $\begin{array}{l}0,0243 \\
(1,57)\end{array}$ & $\begin{array}{c}0,00793 \\
(0,45)\end{array}$ & $\begin{array}{l}-0,134 \\
(-1,57)\end{array}$ & $\begin{array}{c}-0,0154 \\
(-0,44)\end{array}$ \\
\hline Região Sul & $\begin{array}{c}-0,0631 \\
(-5,00)^{\cdots \cdots}\end{array}$ & $\begin{array}{l}0,0310 \\
(2,38)^{*}\end{array}$ & $\begin{array}{c}-0,104 \\
(-3,46)^{\cdots \cdots}\end{array}$ & $\begin{array}{c}0,00892 \\
(0,75)\end{array}$ \\
\hline Região Sudeste & $\begin{array}{c}-0,0609 \\
(-6,55)^{* * *}\end{array}$ & $\begin{array}{c}0,0541 \\
(5,48)^{* * *}\end{array}$ & $\begin{array}{l}-0,0542 \\
(-2,30)^{* *}\end{array}$ & $\begin{array}{c}0,0321 \\
(3,54)^{* *}\end{array}$ \\
\hline Região Centro-Oeste & $\begin{array}{c}-0,0473 \\
(-3,20)^{\cdots \cdots}\end{array}$ & $\begin{array}{c}0,0112 \\
(0,73)\end{array}$ & $\begin{array}{l}-0,0741 \\
(-1,96)^{*}\end{array}$ & $\begin{array}{c}0,0191 \\
(1,35)\end{array}$ \\
\hline Observa & 27.576 & 13.769 & 5.266 & 2.630 \\
\hline Teste mult. Lagrange & $12.687,17$ & $4.098,59$ & $3.631,14$ & 659,99 \\
\hline
\end{tabular}

Obs: Testes t estão entre parênteses abaixo dos efeitos marginais.

${ }^{* * *}$ Denota significância ao nível de $1 \%$

${ }^{* *}$ Denota significância ao nível de $5 \%$

* Denota significância ao nível de $10 \%$ 